\title{
Anti-Inflammatory Activity of Compounds Isolated from Plants
}

\author{
R.M. Perez G. \\ Laboratorio de Investigacion de Productos Naturales. Escuela Superior de Ingenieria \\ Quimica e Industrias Extractivas. IPN. Punto Fijo 16 Col. Torres Lindavista cp 07708. \\ Mexico D.F.
}

Received May 11, 2001; Accepted August 14, 2001; Revised October 13, 2001; Published November 29, 2001

This review shows over $\mathbf{3 0 0}$ compounds isolated and identified from plants that previously demonstrated anti-inflammatory activity. They have been classified in appropriate chemical groups and data are reported on their pharmacological effects, mechanisms of action, and other properties.

KEY WORDS: anti-inflammatory activity

DOMAINS: drug discovery, pathology, inflammation, bioinformatics, pharmacology, medicinal chemistry

\section{INTRODUCTION}

Major research efforts to find new therapeutic agents for a variety of inflammatory skin diseases are motivated mainly by the medical need to find drugs with fewer side effects than the ones currently employed. During the more than 35 years since the introduction of cortisone and phenylbutazone for the treatment of rheumatic diseases, a number of new compounds have been studied for anti-inflammatory activity. Some are also useful in the treatment of fever and gout.

In the treatment of rheumatic diseases, basically two types of drugs are used, nonsteroidal anti-inflammatory drugs (NSAIDs) and disease-modifying antirheumatic drugs (DMARDs). NSAIDs mainly inhibit the cyclo-oxygenase pathway of the arachidonic acid cascade, preventing the formation of proinflammatory prostaglandins. DMARDs are immunomodulators claimed to regulate a distorted immune system[1].

A large number of compounds of varied chemical structures isolated from medicinal plants have been shown to possess anti-inflammatory activity. In this review, over 300 compounds isolated from plants with anti-inflammatory activity are shown. This article is based on bibliographic research of Chemical Abstracts from 1950-2000. It can be helpful to researchers in the study of anti-inflammatory substances from plants. This also may serve as a guide for pharmacologists studying the mechanisms of action and anti-inflammatory effects of these substances. For only a few anti-inflammatory compounds isolated from plants has the principal mechanism of action been determined definitively. 


\section{ALKALOIDS AND NITROGEN COMPOUNDS}

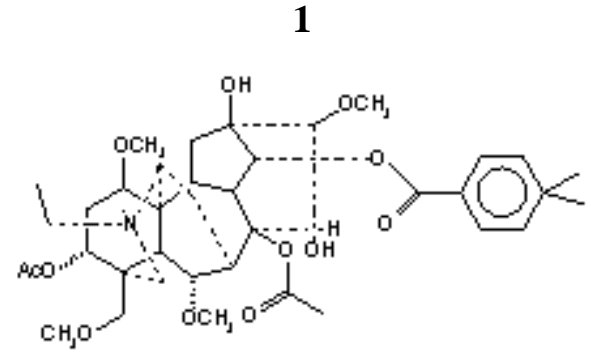

\section{3-Acetylaconitine}

An isoprenoid pathway-derived alkaloid isolated from Aconitum flavum Hand-Mazz and $A$. pendulum Busch, (Ranunculaceae). Increased vascular permeability induced by acetic acid or histamine is considerably inhibited by 3 -acetylaconitine. Edema produced by carrageenan or fresh egg white is also inhibited[2].

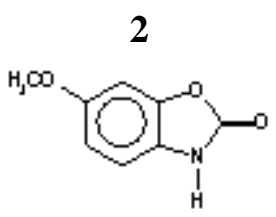

\section{Betonicine}

A piperidine alkaloid found to significantly inhibit carrageenan-induced hindpaw edema[3]. Isolated from Betonica officinalis, Marrubium vulgare, Stachys sylvatica (Labiatae), Achillea moschata, and A. millefolium (Compositae).

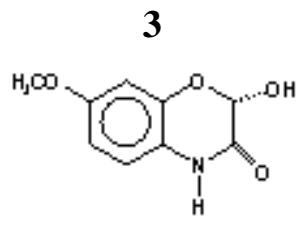

\section{Benzoxazinoid}

The roots of Coix lachryma-jobi have been used in China for the treatment of rheumatism and neuralgia. Two benzoxazinoid compounds isolated from the roots of C. lachryma-jobi L. (Graminae) showed 85.5 and $47.3 \%$ inhibitory activity of histamine release, respectively[4].

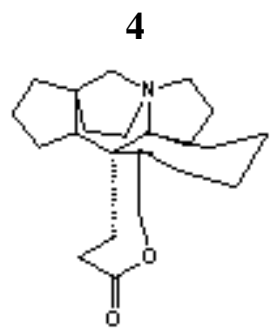

\section{Bukittinggine}

The major alkaloid of Sapium baccatum Roxb. (Euphorbiaceae). Has anti-inflammatory activity on carrageenan-induced hindpaw edema and adjuvant-induced arthritis in rats[5]. This plant is used by indigenous people of West Sumatra, Indonesia in folk medicine for remedies to treat bronchial asthma and to relieve pain. 


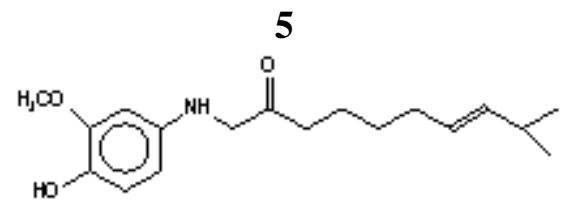

\section{Capsaicin}

A pungent principle of various Capsicum spp. (Solanaceae). Used as a selective probe for studying neurogenic inflammation and the role of nociceptors in human physiology[6].

6

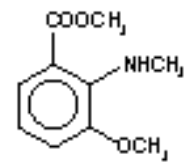

Damascenine

Found in seeds of Nigella damascena and N. arvensis (Ranunculaceae). Inhibits induced edema formation in the paw[4].

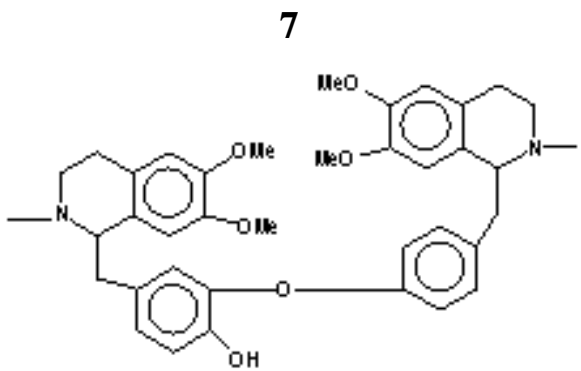

\section{Dauricine}

In traditional Chinese medicine, dauricine, an alkaloid isolated from Menispermun dauricum DC. (Menispermaceae) roots, has been used for testing rheumatism and is toxic $\left(\mathrm{LD}_{50}\right.$ i.p. in mice 6 $\left.\mathrm{mg} / \mathrm{kg}^{-1}\right)[7]$.

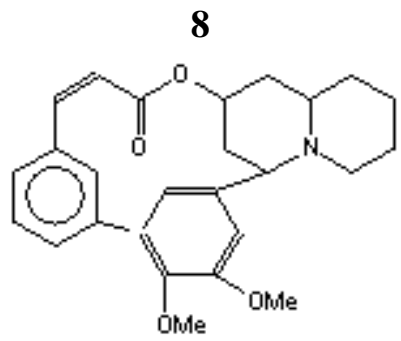

Decinine

Found in Lythrum lanceolatum L. (Lythraceae). Has anti-inflammatory activity[8]. 


\section{9}

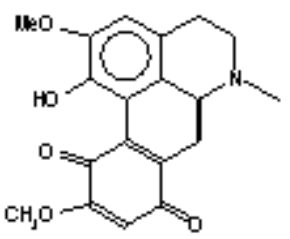

\section{Demethylsonodione}

Found in the stem bark of Hernandia sonora L. (Hernandiaceae). Showed moderate antiplatelet aggregation activity in vitro[9].

\section{0}

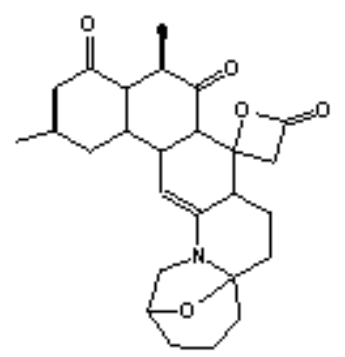

\section{Deoxyzoanthenamine}

Isolated from an unidentified colonial Zoanthid of the genus Zoanthus. A potent antiinflammatory and analgesic agent[8].

\section{1}

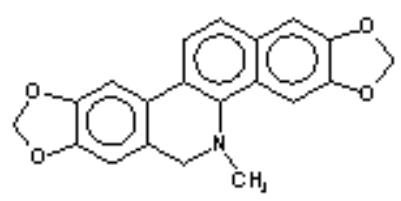

\section{Dihydrosanguinarine}

A benzophenanthridine alkaloid found in Fumaria parviflora (Papaveraceae). Activity and uses similar to those of sanguinarine. Used as antiseptic and anti-inflammatory agents[3].

12

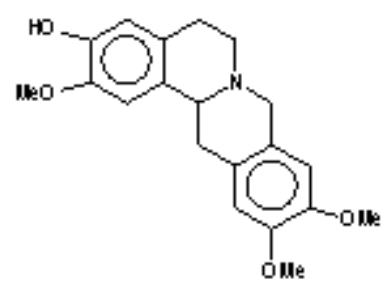

Discretine

Found in Xalopia discreta. Claimed to have analgesic, anti-inflammatory activity[10]. 
13

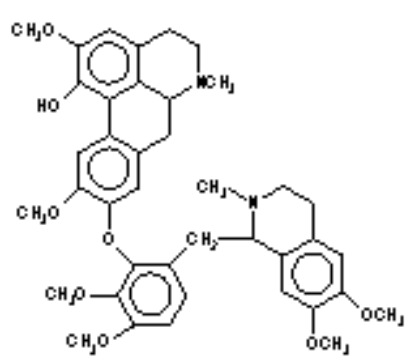

Fetidine

An isoquinoline alkaloid that is anti-inflammatory, hypotensive, and depresses nervous activity in mice[11]. Isolated from Thalictrum foetidume (Ranunculaceae) leaves.

14

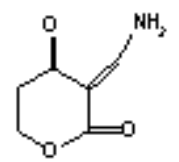

Gentianaine

Showed low anti-inflammatory activity in carrageenan-induced hindpaw edema[12]. Isolated from Gentiana caucasa (Gentianaceae) leaves.

15

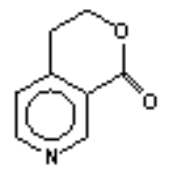

Gentianadine

A sesquiterpene alkaloid found in the aerial parts of Gentiana turkestanorum, G. olgae, and G. olivieri (Gentianaceae). Shows anti-inflammatory and muscular relaxant actions[12].

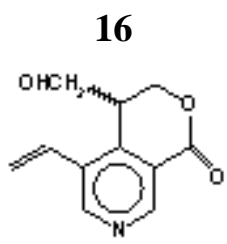

Gentianamine

Showed anti-inflammatory activity in carrageenan-induced hindpaw edema[12]. Isolated from leaves of Gentiana olivieri and G. turkestanorum (Gentianaceae). 
17<smiles>COc1cc(O)c2c(c1)CN(C)C1Cc3cc(O)c(O)cc3C1C2</smiles>

Glaucine

Found in a wide variety of genera in the Annonaceae (Alphonsea, Annona, Polyalthia, and Uvaria). Shows analgesic and anti-inflammatory activity[8].

18

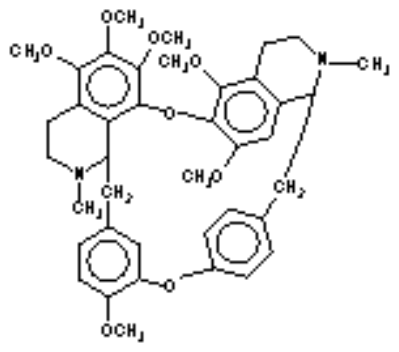

Hernandezine

Isolated from Stephania hermandifolia (Menispermaceae) and Thalictrum simplex (Ranunculaceae) leaves and studied in the rat paw carrageenan and the cotton pellet granuloma[13].

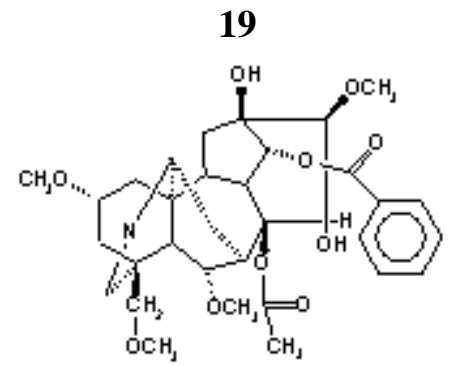

Hypaconitine

Betalain alkaloid obtained from Aconitum collianthum, A. carnichaeli, and A. napellus (Ranunculaceae). Showed significant inhibitory activity against carragenan-induced edema[14].

20<smiles></smiles>

Isothebaine

Isolated from Papaver orientale and P. bracteatum (Papaveraceae). Shows analgesic and antiinflammatory activity[8]. 
21

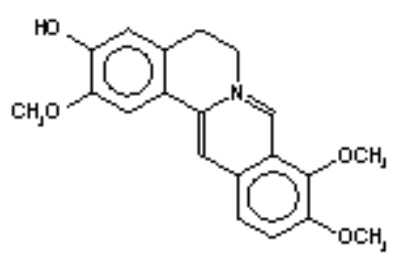

Jatrorrhizine

Alkaloid isolated from methanol extract of cultured Plagiorhegma dubium Maxim (Berberidaceae). Has shown anti-inflammatory activity[15].

22

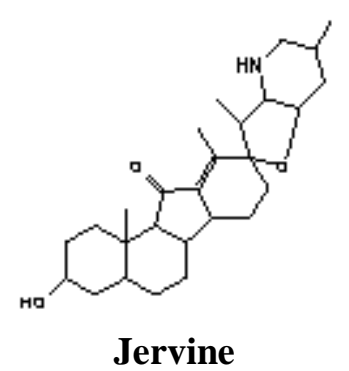

Some Veratrum alkaloids, namely jervine (and jervine derivatives) and protoveratrine, exhibited anti-inflammatory activity when administered subcutaneously. They decreased both exudative and proliferative phases consequent to subcutaneous implantation of wool pellets[16]. Isolated from Veratrum lobelianum (Liliaceae) leaves.

23

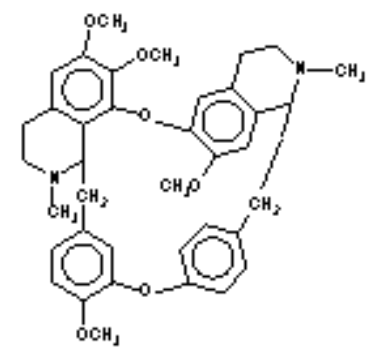

(+)-O-Methylthalicberine (or Thalmide)

Another alkaloid isolated from leaves of Lictrum spp. (Ranunculaceae) and Berberis laurina (Berberidaceae). Prevented the development of the paw carrageenan edema[17].

\section{4}<smiles>Cc1cc(O)c2c(c1)-c1c(O)cc(C)cc1N(C)CC2</smiles>

\section{Ocoteine}

Occurs in Ocotea puberula (Lauraceae). Shows analgesic, antimicrobial, and anti-inflammatory activity[8]. 


\section{$\mathrm{CH}_{3}-\left(\mathrm{CH}_{2}\right){ }_{14} \mathrm{CONHCH}_{2} \mathrm{CH}_{2} \mathrm{OH}$}

\section{Palmidrol}

Occurs in soya bean lecithin. Shows analgesic, antimicrobial, and anti-inflammatory activity[8].

26

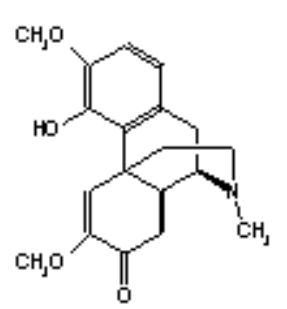

Sinoacutine

Antizoma angustifolia Burch. (Menispermaceae) leaves yielded a morphinandienone-type alkaloid sinoacutine in $2.8 \%$ yield. Alkaloid exhibited slight anti-inflammatory activity[18].

27

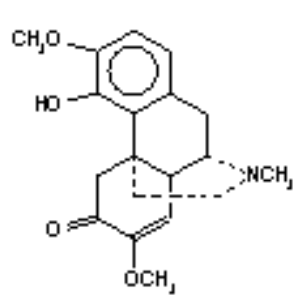

Sinomenine

A major alkaloid of the traditional Chinese drug plant Sinomenium acutum Thunb. Has marked anti-inflammatory activity[19].

28

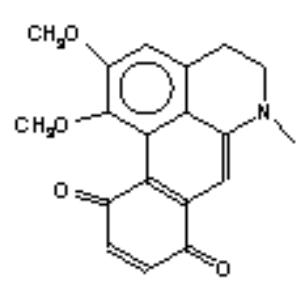

Sonodione

Found in the stem bark of Hernandia sonora L. (Hernandiaceae). Showed moderate antiplatelet aggregation activity in vitro[9]. 


\section{9}

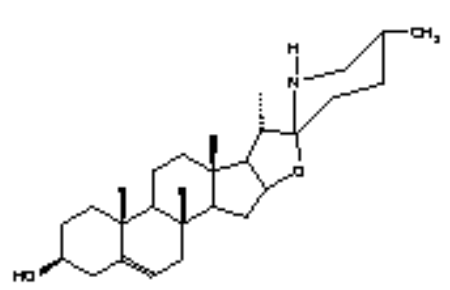

Solasodine

Caused significant dose-dependant inhibition of carrageenan-induced paw edema[20]. Isolated from Solanum lacintatum (Solanaceae) leaves.

$$
\mathrm{C}_{14} \mathrm{H}_{23} \mathrm{NO}
$$

\section{Spilanthol}

Alkaloid isolated from the roots of Sapilanthes olereaceae. Has anti-inflammatory activity on carrageenan-induced hindpaw edema and adjuvant-induced arthritis in rats[6].

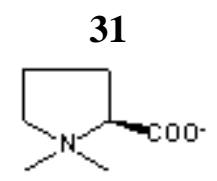

\section{Stachydrine}

Found in Stachys spp. (Leguminosae). Widely used against rheumatism and many other diseases. Also a systolic depressant[8].

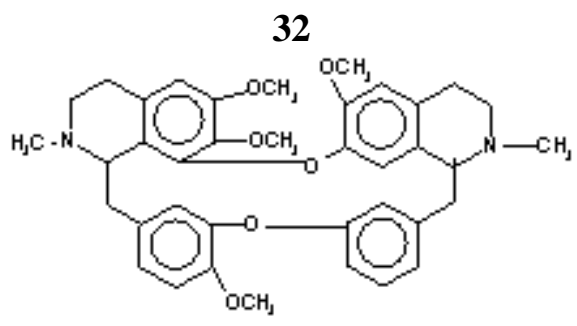

\section{Tetrandrine}

Isolated from root of Stephania tetrandra S. Moore. Exhibits definitive antiphlogistic action on formaldehyde-induced arthritis of rats[21].

\section{3}

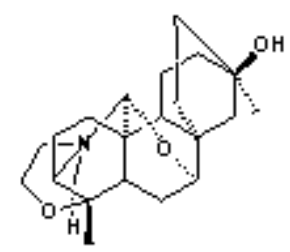

\section{Thalicsiline}

A spiradine-type C20-diterpenoid alkaloid isolated from the roots of Thalictrum sessile Hayata (Ranunculaceae). Has anti-inflammatory activity[22]. 


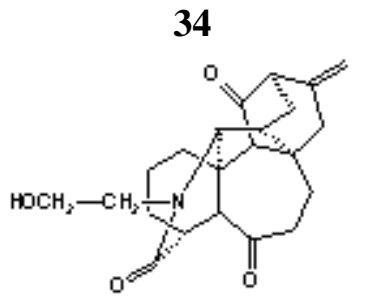

Thalicsessine

The first ajaconine-type $\mathrm{C} 20$ diterpene alkaloid having an oxygen function at C-20. Isolated from Thalictrum sessile (Ranunculaceae). Showed $40 \%$ reduction of carrageenan-induced inflammation at $20 \mathrm{mg} / \mathrm{kg}[12]$.

\section{5}

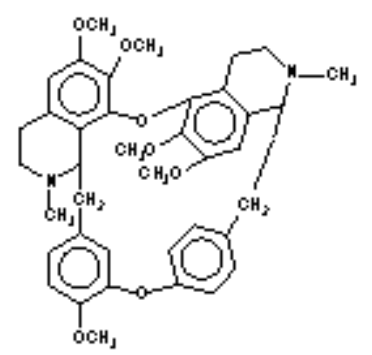

Thalidasine

The leaves of Thalictrum dasycarpum (Ranunculaceae) are reported to be applied to rheumatic swelling of joints and sprains. Exhibited anti-inflammatory activity in carrageenan-induced hindpaw edema[13].

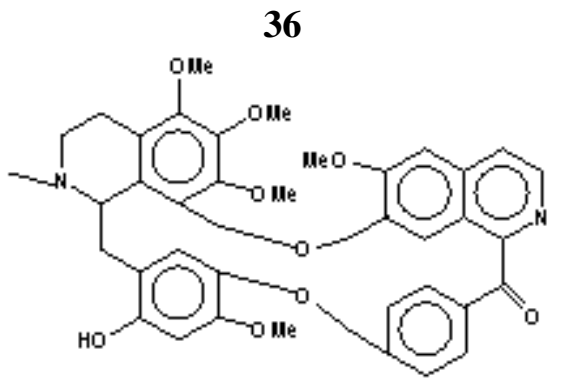

Thalictrinine

Occurs in Thalictrum rochebrunianum (Ranunculaceae). Shows strong anti-inflammatory activity and weak antitumor agent[8].

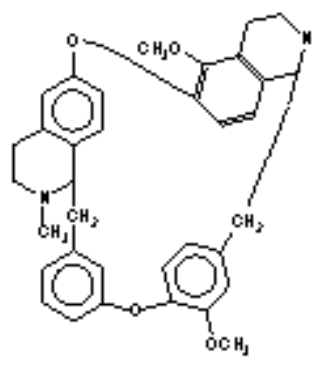

Thalmine 
Showed anti-inflammatory activity in several experimental models of inflammation in animals. Antitumor activity shown against ascites lymphoma in rats and mice[13]. Isolated from Thalictrum spp. (Ranunculaceae) leaves.

38

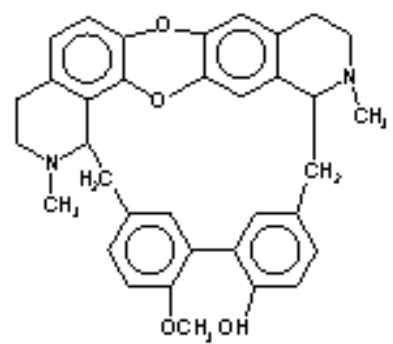

Trilobine
39

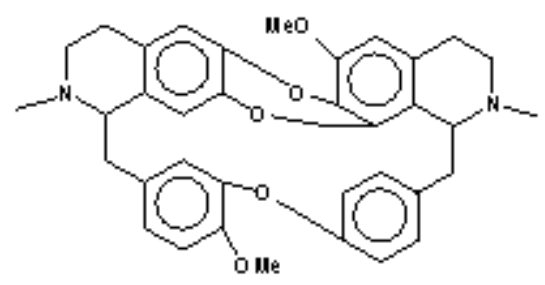

Isotrilobine

Two alkaloids, trilobine and isotrilobine, isolated from roots of Cocculos trilobus (menispermaceae) showed inhibitory effect against cotton pellet and adjuvant arthritis in rats[23].

\section{0}

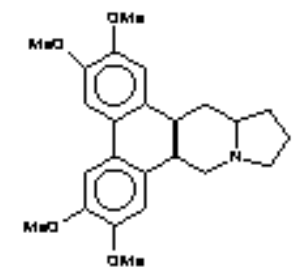

Tylophorine

Inhibited the primary and secondary responses of adjuvant-induced arthritis[24]. Isolated from Tylophora indica (Burn. L.) Mirr (Asclepiadaceae) leaves.

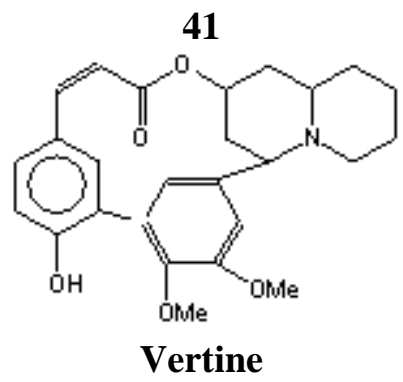

Found in Lagerstroemia faurei (Lythraceae). Shows hypotensive and anti-inflammatory activity[8].

42<smiles>CC(C)[C@H](O)c1ccccc1</smiles>

Pseudoephedrine
43<smiles>CC1NC(=O)OC1c1ccccc1</smiles>

Ephedroxane

Since the traditional usage of an Oriental medicine "mao", consisting of Ephedra herbs (Ephedra intermedia, Ephedraceae) suggests that it may possess anti-inflammatory activity. The methanol extract was fractionated, resulting in the isolation of $(+)$ pseudoephedrine[25] and a new alkaloid 
designated as ephedroxane. The anti-inflammatory effects were determined on carrageenan paw edema in mice, Whittle method and the fertile egg method[26].

44<smiles>COc1cccc(CN2C3CCCCC2CC(OCc2ccc(O)cc2-c2cc(O)c(OC)cc2O)C3)c1</smiles>

Cryogenine
45<smiles>COc1ccc(C2CCCOCCOCCO2)c(-c2ccccc2O)c1O</smiles>

Nesodine

Two alkaloids, cryogenine and nesodine, isolated from Heimia salcifolia Link and Otto (Lythraceae) were shown to be 2.48 and 2.24 times as potent as aspirin in inhibiting the prostaglandin synthetase prepared from bovine seminal vesicles. Have been shown to exert antiinflammatory activity in different systems[27].

46

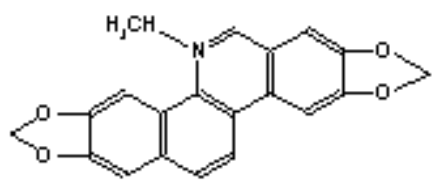

Sanguinerine
47

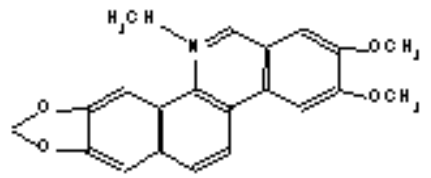

Chelerythrine
48<smiles>CN1Cc2cc3c4cc2C(OCO4)C1c1cc2c(cc1C[C@H]2O)OCO3</smiles>

Chelidonine

The orange-colored latex of Chelidonium majus L. (Papaveraceae) contains high concentrations of benzophenanthridine alkaloids, specially of the main alkaloids chelidonine[28], chelerythrine, and sanguinarine[29]. The chelerythrine and sanguinarine are, to a great extent, responsible for anti-inflammatory and antimicrobial action. Recommended for medical use in the treatment of oral inflammatory processes. C. majus is a popular medicinal herb commonly widespread in Central Europe and represents a rich source of benzophenanthridine alkaloids.

49<smiles>Cc1cc(=O)c2c(O)cc(O)c(C3CCN(C)CC3O)c2o1</smiles>

Rohutikin
50<smiles>CC1(C)C(=O)CCC2(C)C3CCC4(C)C(CCC4(C)C)C3C(O)C(O)C12</smiles>

Dysobinin

Dysobinin, a new tetranortriterpene of the meliacin group showing general CNS-depressant action and mild anti-inflammatory activity, was isolated from the fruits of Dysoxylum binectariferum Hook. (Meliaceae)[30]. The alkaloid, rohutikin, isolated from the stem bark is an iperidinylbenzopyranone. Displayed anti-inflammatory activity in carrageenan-induced rat paw edema and inhibited the reverse passive Arthus reactions in rats $(50.8 \%$ inhibition at $2.5 \mathrm{mg} / \mathrm{kg}$, p.o.)[31]. 


\section{COUMARINS}

\section{1}<smiles>CC=C(C)C(=O)C1=C(OC)C2=C(C=CC(C)(C)O2)C2C(C)=CC(O)OC12</smiles>

\section{Calophyllolide}

A nonsteroidal anti-inflammatory agent found to be effective in reducing the increased capillary permeability induced in mice by various chemical mediators involved in the inflammatory process viz., histamine, 5-hydroxytryptamine, and bradykinin[32]. Caused a decrease of $60.7 \%$ in the rat paw carrageenan edema at a dose of $40 \mathrm{mg} / \mathrm{kg}$ i.p. Its activity was compared with that of hydrocortisone, which at a dose of $10 \mathrm{mg} / \mathrm{kg}$ inhibited the edema by $44 \%$. Showed the greatest anticonvulsant activity in rodents[33]. Isolated from Kernel of Calophyllum mophyllum Linn. (Guttiferae).

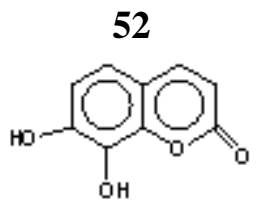

\section{Daphnetin}

Has displayed analgesic, sedative, and anti-inflammatory effects in a series of animals test[34]. Isolated from Daphne giraldii Nitsche (Thymelaeaceae) leaves.

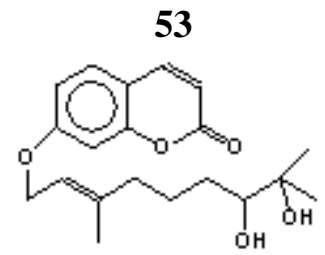

\section{Marmin}

Isolated from roots of Aegle marmelos Correa (Rutaceae). Showed anti-inflammatory effects in carrageenan-induced inflammation in rats[35].

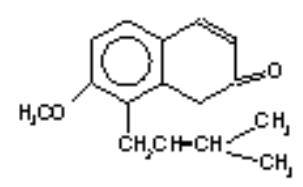

\section{Osthol}

The methanol extract of the root of Angelica pubescens Maxim. (Umbelliferae) was fractionated, and by following the inhibitory activities on rat hind edema induced by carrageenan and on writhing induced by acetic acid in mouse. The active principle was isolated and identified as osthol[36]. This plant has been used in traditional Chinese medicine as a remedy for arthritic disease, lumbago, edema, and the common cold. 
55

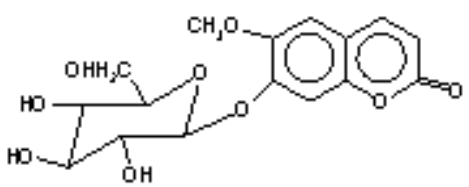

Scopolin
56

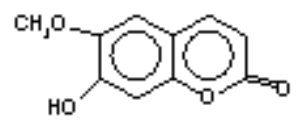

Scopoletin

Obtained from Scopolia japonica (Solanaceae). Demonstrate anti-inflammatory activity against acute albumin- or histamine-induced edema of hindpaws and acute subacute joint swelling caused by formaldehyde. Both compounds also exhibit analgesic effects[37].

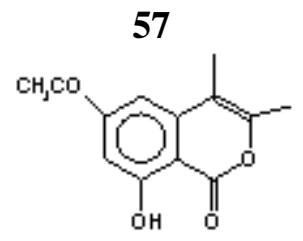

Polygonolide

A new isocoumarin. Inhibits the reversed passive Arthus reaction in rats via oral administration. Isolated from the methanol extract of the root of Polygonum hydropiper Linn. (Polygonaceae)[38].

58<smiles>CCc1ccc2c(c1)OC(O)C=C2</smiles>

Herniarin
59<smiles>O=c1ccc2cc(O)c(O)cc2o1</smiles>

Aesculetin

Isolated from Santolina oblongifolia Boiss (Compositae). These coumarins showed considerable activity as inhibitors of eicosanoid release from ionophore-stimulated mouse peritoneal macrophages[39].

\section{FLAVONOIDS}

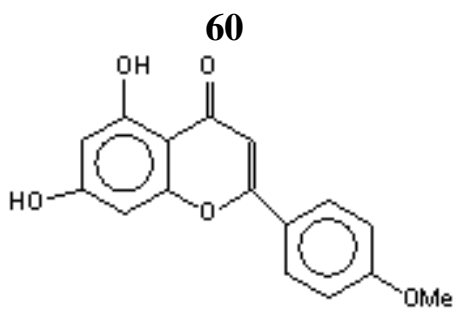

Acacetin

Found in Robinia pseudocacia. Is an anti-inflammatory, capillary protective, and spasmolytic agent[8]. 


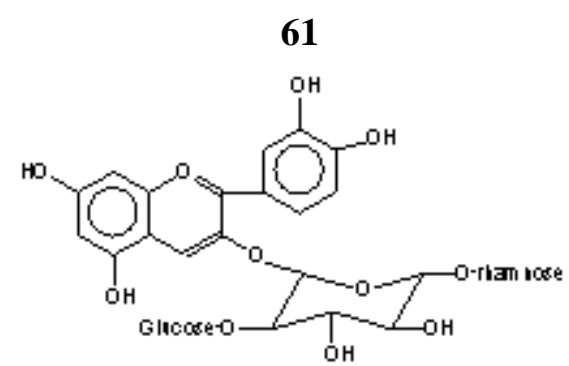

Anthocyanin 1
62

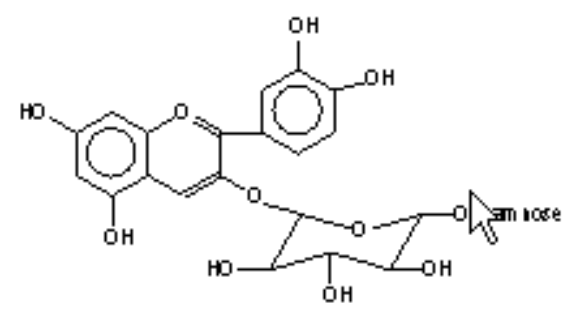

Anthocyanin 2

Occur in tart cherries. Exhibit antioxidant and anti-inflammatory activities comparable to commercial products[40].

63<smiles>COc1ccc(C2CC(=O)c3c(cc(O)c(C)c3O)O2)cc1</smiles>

\section{Apigenin 7,4'dimethyl ether}

Isolated from roots of Rhus undulata Jacq. (Anacardiaceae). Active on rat paw carrageenan edema with $\mathrm{ED}_{25}=75 \mathrm{mg} / \mathrm{kg}$, while hydrocortisone phosphate and nobiletin were more potent: $\mathrm{ED}_{25}=13.5$ and $20 \mathrm{mg} / \mathrm{kg}$, respectively[41].

64<smiles>COc1ccc(-c2oc3cc(OC)c(OC)c(O)c3c(=O)c2OC)cc1OC</smiles>

Artemetin

This 5-hydroxy-3,6,7,3',4'-pentamethoxyflavone from the leaf of Cordia verbenacea (Boraginaceae) showed marked anti-inflammatory activity using various experimental models in rats. Also reduced the vascular permeability to intracutaneous histamine. Subacute toxicological experiments indicated a very low toxicity[42]. Extract for leaves of $C$. verbenaceae are used in Brazilian folk remedies as anti-inflammatory and cicatrizing agents[43].

65

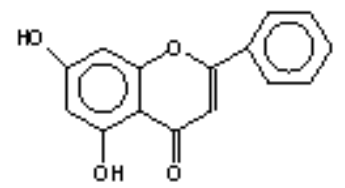

Chrysine

The flavonoid fraction of leaves of Populus spp. (Salicaceae) inhibits croton oil dermatitis in the mouse ear. This activity is mainly due to chrysin[41]. 
Epicatechin, catechin, procyanidin $\mathrm{B}_{2}$ and $\mathrm{B}_{4}$, cinnamonol $\mathrm{D}_{1}$ and $\mathrm{D}_{4}$ isolated from aq. methanol extract of the bark of Cinnamomun sieboldii Meissn. (Lauraceae). Had potent inhibitory activity on the formation of granulation tissue through screening by the fertile egg methods[44]. The activity increased in the order of monomers, dimers, and trimers. Catechin is able to decrease carrageenan edema (ID $=240 \mathrm{mg} / \mathrm{kg}$, i.p.), while at a lower dose $(40 \mathrm{mg} / \mathrm{kg} \mathrm{s.c.}$ ) moderately inhibited rat paw edema induced by serotonin.

68

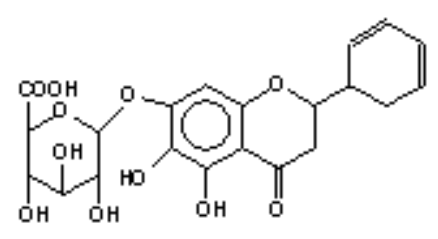

Baicalin
69<smiles>O=C1CC(C2C=CC=CC2)Oc2cc(O)c(O)c(O)c21</smiles>

Baicalein
70<smiles>COc1cc(O)cc(C2Oc3cc(O)c(C)c(O)c3C(=O)[C@H]2O)c1</smiles>

Wogonin

The main flavonoid components of leaves of Scutellaria baicalensis Georgi (Labiatae) baicalin, baicalein, and wogonin - have been screened in comparison with three standard antiinflammatory agents - phenylbutazone, indomethacin, and dexamethasone - for activity in various experimental models of inflammation. All of the test substances were found to inhibit an increase in vascular permeability in mice induced by acetic acid and to reduce acute paw edema in rats. They also suppressed the secondary lesion in developing adjuvant-induced arthritis in rats[45]. The mechanism of their anti-inflammatory action depends on inhibition of enzymes such as 12-lipoxygenase and 5-lipoxygenase. S. baicalensis (Ogon in Japanese) has been used for treatment of some types of dermatitis, diarrhea, and various inflammatory diseases as an antiphologistic and antipyretic in the traditional Chinese system of medicine.

\section{1}

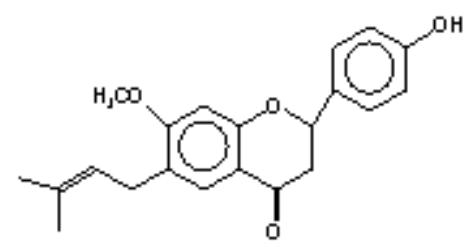

Bavachinin

A phenol compound isolated from the leaves of Psoralea coryfolia Linn (Leguminosae) has shown anti-inflammatory activity[46].

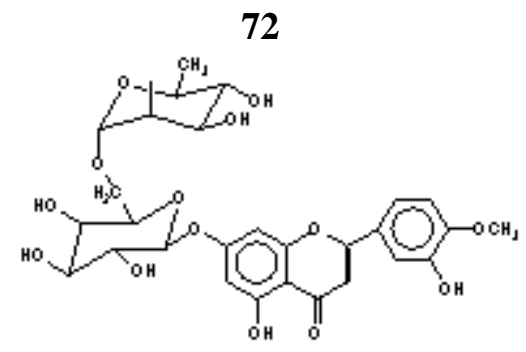

Diosmin 
Exhibited anti-inflammatory activity and increased skin capillary resistance[47]. Isolated from leaves of Diosma crenulata (Rutaceae).

73<smiles>COc1cc(OC)c2c(=O)cc(-c3ccccc3)oc2c1</smiles>

\section{5-7-Dimethoxyflavone}

Isolated from black rhizomes of the Boesenbergia pandurata Robxb. Zingiberaceae, the antiinflammatory activity has been assessed. Found to possess comparable effects to aspirin on the rat edema model, and showed no inhibition on cotton pellet-induced granuloma formation. On the rat pleurisy model, it exhibited an antiexudative effect, interfered with leukocyte migration, and markedly inhibited prostaglandin biosynthesis[48].

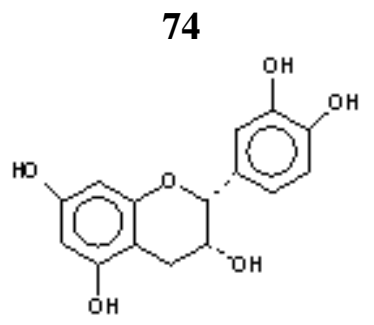

Epicatechin

A catechin with significant anti-inflammatory activity isolated from the seed of the plant Anacardium occidentale Linn (Anacardiaceae)[49].

75<smiles>Oc1ccc([C@H]2Oc3cc(O)cc(O)c3C[C@H]2O)cc1</smiles>

(-)Epiafzelechin

An inhibitor of cyclo-oxygenase (COX-1) activity of prostaglandin $\mathrm{H}_{2}$ synthase. Isolated from aerial parts of Celastrus orbiculatus (Celastraceae). An Oriental folk medicine for rheumatoid arthritis[50].

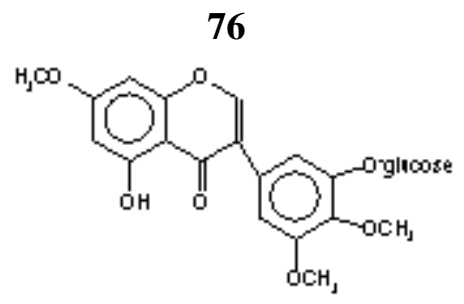

Flavan-3-ol, (+)-catechin

Showed suppression of carrageenan-induced rat paw edema as well as TPA-induced rat ear edema (tetradecanoylphorbol acetate)[51]. Isolated from the bark of Ceiba pentandra L. Gaether. 


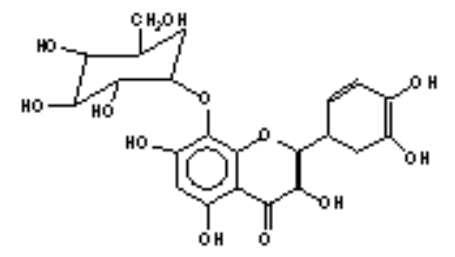

\section{Gosspyn}

Glycoside (gossypetin-7-glucoside) from the flowers of Hibiscus vitifolius L. (Malvaceae). Inhibits the carrageenan rats paw edema[27].

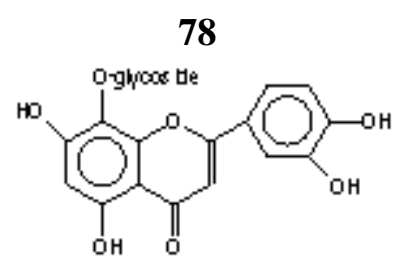

\section{Hypolaetin-8-glucoside}

Had an interesting anti-inflammatory profile. This glucoside was more potent than phenylbutazone in suppressing the acute phase of the adjuvant-carrageenan-induced inflammation, but was less effective in the prolonged phase[52,53]. Isolated from leaves of Sideritis mugronensis (Labiatae).

79

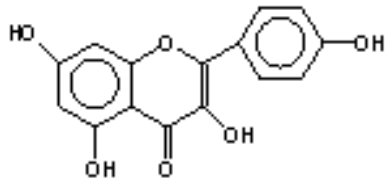

\section{Kaemferol 3,5,7,4'tetrahydroxyflavone}

Isolated from flowers of Aesculus hippocastanum (Hippocastanaceae). Shows anti-inflammatory, antibacterial, and mutagenic activities[41].

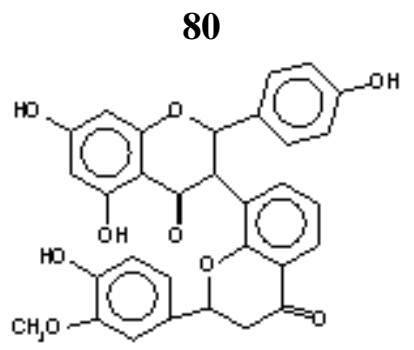

\section{Kolaflavanone}

Isolated from the rind of the fruit of Garcinia kola (Guttiferae). Inhibited primary and secondary responses of adjuvant induced arthritis in rats[54]. 


\section{1}

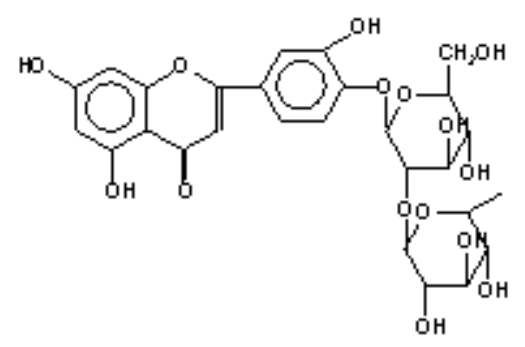

\section{Luteolin-4'-neohesperidoside}

This flavonoid glycoside was isolated from Caralluma attenuata (Asclepiadaceae). Has antiinflammatory activity[55].

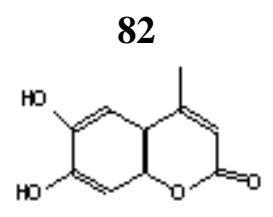

\section{Methyl 4-esculetol}

Showed activity against initial symptoms of inflammation carrageenan edema, dextran edema, histamine wheal, and peritoneal permeability[56]. Isolated from leaves of Ruscus aculeatus L. (Liliaceae).

83<smiles>COC1=C(c2ccc(O)c(CC=C(C)C)c2O)Oc2cc(O)cc(O)c2C1O</smiles>

Podaverine A

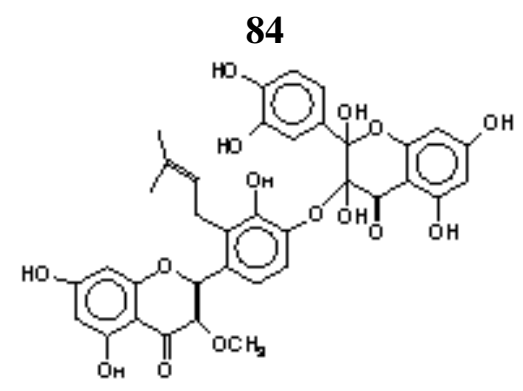

Podoverine B

Isolated from cell culture of leaves of Podophyllum versipelle Hance (Berberidaceae). Showed inhibitory activities in the mouse macrophage chemiluminescense (CL) assay and are responsible for the activity of the corresponding callus culture. Preliminary in vivo studies indicate that the compounds have anti- inflammatory activity. These inhibitory activities are comparable to those of the antioxidant compound quercetin and nordihydroguaiaretic acid[57].

\section{5}

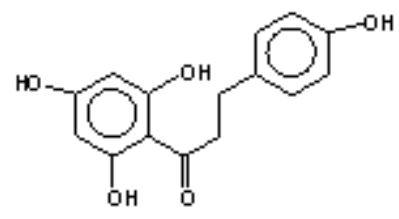

\section{Phloretin}

Occurs as the $2^{\prime}$-glucoside, specially in Rosaceae, Ericaceae, and Symplocaceae. Showed antiinflammatory activity[58]. 


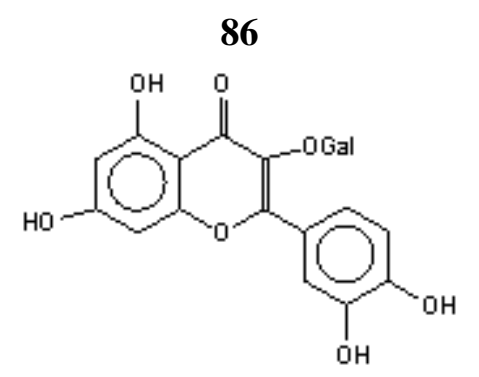

Quercetin-3-O-galactoside

Exhibited anti-inflammatory activity comparable to phenylbutazone in carrageenan-induced rat paw edema model[59]. Isolated from leaves of Physalis minima Linn (Solanaceae).

87<smiles>CC1OC2C1CC1OC(Oc3c(-c4ccc(O)c(O)c4)oc4cc(O)cc(O)c4c3=O)C2O1</smiles>

Quercetin 30-rhamnoside
88

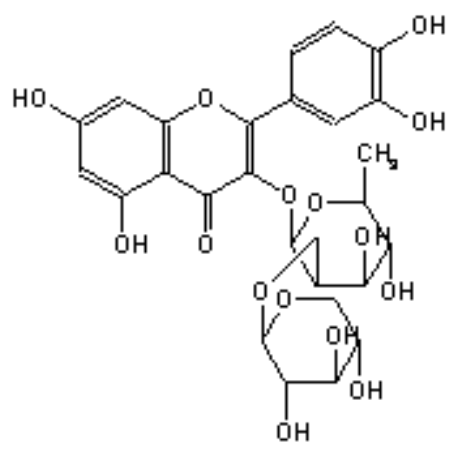

Quercetin 30-xylosyl $(1 \rightarrow 2)$ rhamnoside

Two anti-inflammatory principles - quercetin 3O-xylosyl $(1 \rightarrow 2)$ rhamnoside and quercetin 3Orhamnoside - isolated from the methanol extract of the leaves of Erythrospermum monticolum. Active against the acute inflammation in mice induced by TPA (12-O-tetradecanoylphorbol acetate) producing significant reductions in edema. Their activity is in range of the wellestablished reference drug, indomethacin[60]. Quercetin, quercetin 3-rhamnoglucoside and 3galactoside, rutin has been claimed to be the anti-inflammatory principle of E. monticolum (Flacourtiaceae), Wrighitia tinctoria (Apocynaceae), and Delonix elata Gamble (Leguminosea) flowers active on carrageenan edema.

89

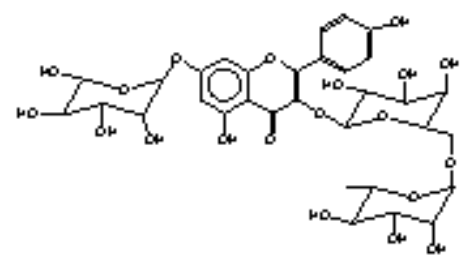

Robinin

The kaempferol glycoside robinin isolated from Robinia pseudacacia Borja (Leguminosae) leaves inhibits the exudative and proliferative phases of the cotton pellet granuloma (50 $\mathrm{mg} / \mathrm{kg} /$ day p.o. in 7 days)[56]. Used as an anti-inflammatory and antirheumatic agent in Spain's folk medicine. 
90<smiles>O=C1c2c(O)cc(O)cc2OC(c2ccc(O)c(O)c2)[C@@H]1O</smiles>

Taxifolin
91

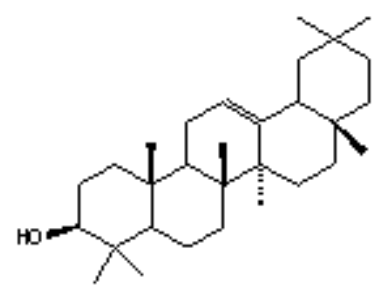

$\alpha$-Amyrin

Taxifolin and $\alpha$-amyrin from the seed of Cordia obliqua Wild. (Boraginaceae) showed significant anti-inflammatory activity[41]. The polar fraction of the plant extract Cedrus deodara (RoxB) Loud. (Pinaceae) was found to exhibit anti-inflammatory activity in carrageenan-induced edema in mice and its chemical examination has resulted in the isolation of dihydroflavanonols[61].

92

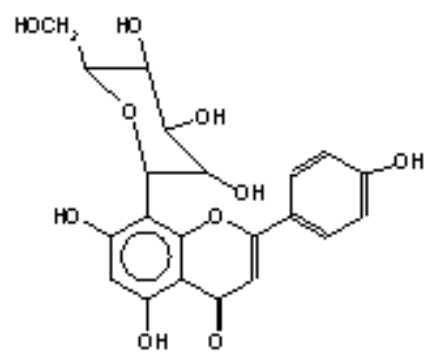

Vitexin

(8- $\beta$-D-glucopyranosyl-apigenin) (VT). Isolated from the roots and flowers of Arnebia nobilis, A. gullata, A. benthamii, A. hispidissima DC. (Boraginaceae), and Ochrocarpus longifollus L. (Guttiferae). Exhibited potent hypotensive, anti-inflammatory, and antispasmodic properties. An anti-inflammatory effect probably related to its antihistamine, antibradykinin, and antiserotonin properties[62].

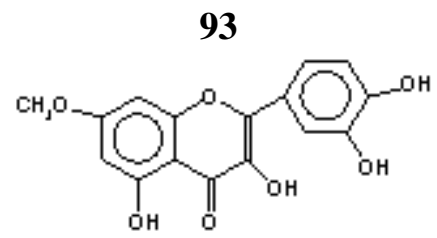

\section{Xanthorhamnin}

Isolated from the seeds of Rhamnus infectoria (Rhamnaceae). Has been patented as an antiinflammatory agent and recommended for the treatment of rheumatoid arthritis and for use in ophthalmology[63].

\section{4}<smiles>O=c1cc(-c2ccc(O)cc2)oc2cc(O)cc(O)c12</smiles>

Apigenin
95<smiles>O=c1cc(-c2ccc(O)c(O)c2)oc2cc([18OH])cc(O)c12</smiles>

Luteolin

Apigenin and luteolin showed a potency similar to indomethacin $\left(\mathrm{ID}_{50}=29.8\right.$ and $38.4 \mu$ per ear, respectively). $18 \mathrm{~h}$ after the treatment, only luteolin maintained its effects on edema development 
but the three compounds decreased leukocyte infiltration[64]. Isolated from leaves of Chamomilla recutita $\mathrm{L}$. (Compositae).<smiles>Oc1cc(O)c2c(c1)O[C@H](c1ccc(O)c(O)c1)C(O)C2</smiles>

Catechin
97

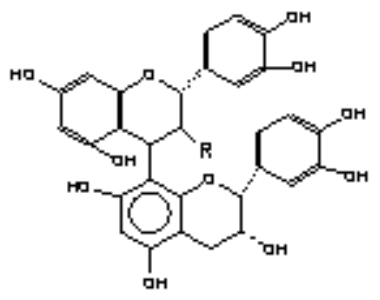

98

Procyanidin $\mathrm{B}_{4} \mathrm{R}=-\mathrm{OH}$

Isolated from Cinnamomun sieboldii[44].

99<smiles>O=C1c2c(cc(O)c(O)c2O)OC(c2ccc(O)cc2)C1O</smiles>

6-Hhydroxykaempferol,3,6-dimethyl ether 6-Hydroxykaemperol-3,6-dimethyl ether has an equivalent profile of enzyme inhibitory activity to santin in both assay (cyclo-oxygenase and 5-lipoxygenase pathways), but is less potent. Quercetagetin 3,6,3'-trimethyl ether shows preferential activity against cyclo-oxygenase with much less activity in inhibiting 5-lipoxygenase[65]. Isolated from Tanacetum parthenium and $T$. vulgare (Compositae)[66].

101<smiles>Oc1cc(O)c2c(c1)O[C](c1cc(O)c(O)c(O)c1)C(O)C2</smiles>

Gallocatechin
102<smiles>Oc1cc(O)c2c(c1)OC(c1cc(O)c(O)c(O)c1)[C@H](O)C2</smiles>

4'-O-methyl-ent-gallocatechin
103<smiles>COc1cc(O)c2c(c1)OC(c1cc(O)c(O)c(O)c1)C(O)C2</smiles>

Ouratea-catechin

All catechin isolated from Atuna racemosa (Chrysobalanaceae) and Syzygium corynocarpum (Myrtaceae) exhibited strong to medium inhibition of COX-1 catalysed prostaglandin biosynthesis in vitro[67]. 
104<smiles>C=C(C)[C@@H](C1=CC(=O)C(O)=CC1O)c1ccccc1</smiles>

(S)-4-methoxydalbergione

107

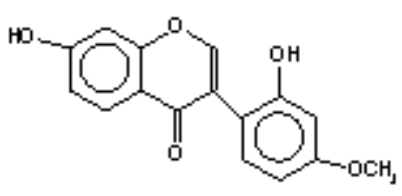

Xenognosin
105<smiles>O=C(C1=CC(O)C(O)C=C1O)c1ccccc1</smiles>

Cearoin

108<smiles>O=C(/C=C/c1ccc(O)c(O)c1)c1ccc(Br)cc1O</smiles>

Butein
106

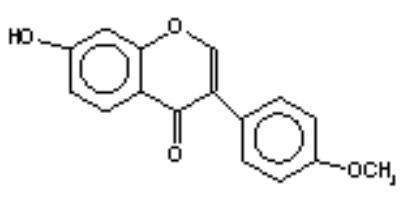

Koparin

109<smiles>O=c1c(C2=CC(O)C(O)=CC2O)coc2cc(O)ccc12</smiles>

Bowdichione

110<smiles>COc1ccc(C2COc3cc(O)ccc3C2=O)c(O)c1OC</smiles>

3-O-methylviolanone

Found in heartwood of Dalbergia odorifera T. Chen. (Leguminosae). A traditional Chinese medicine known as jiangxiang. Has been used to treat blood disorders, ischemia, swelling, necrosis, and rheumatic pain. Showed significant anti-inflammatory activity[68].

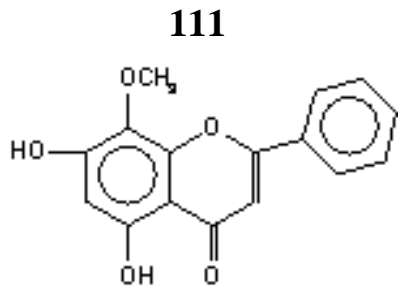

Wogonin

Found in the root of Scutellaria baicalensis Georgi (Labiatae). Inhibited IL-1 $\beta$-induced synthesis of $\mathrm{PGE}_{2}$ and $\mathrm{LTB}_{4}$ considerably. In addition, these compounds exerted a moderate inhibition of collagenolytic activity and the cellular activity of fibroblast was increased remarkably[69]. 


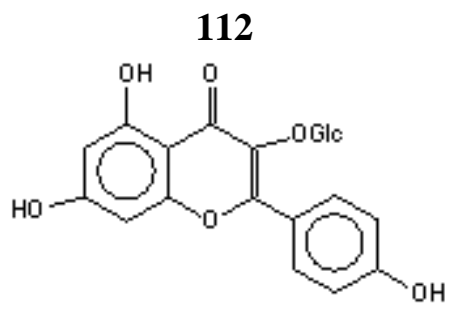

\title{
Kaempferol-3-O-sophoroside (K3S)
}

A polyphenolic constituent isolated of the alcoholic extract of the leaves of Cassia alata L. (Leguminosae). Has been investigated for anti-inflammatory activity and the results compared with phenylbutazone. Showed a significant anti-inflammatory effect in rats in carrageenan and induced hind paw edema test[70]. C. alata is used in India for skin diseases like eczema, pruritis, and itching.

\section{MISCELLANEOUS COMPOUNDS}

\section{3}

\section{$\mathrm{CH}_{2}=\mathrm{CHCH}_{2} \mathrm{~S}(\mathrm{O}) \mathrm{CH}_{2} \mathrm{CH}=\mathrm{CHSSCH}_{2} \mathrm{CH}=\mathrm{CH}_{2}$}

\begin{abstract}
Ajoene
Isolated from garlic (Alium sativum, Liliaceae). Showed potent inhibition of platelet aggregation[8].
\end{abstract}

114

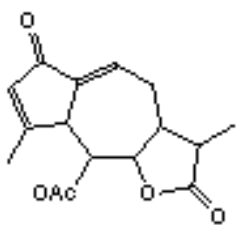

Arnicolide

Inhibited the carrageenan- and formaldehyde-induced inflammation. Isolated from Arnica montana (Compositae) leaves[71].

\section{5}<smiles>COc1cccc2c1cc(O)c1c(C(O)O)cc3c(c12)OCO3</smiles>

\section{Aristolich acid}

Inhibited the carrageenan- and formaldehyde-induced inflammation[72]. Isolated from leaves of Aristolochia clematis (Aristolochiaceae). 


\section{6}

\section{Bromelain}

A basic glycoprotein isolated from the fruit pineapple (Ananas comosus, Bromiliaceae). This proteolythic enzyme is used medicinally as an anti-inflammatory agent in soft tissue edema and injury[73].

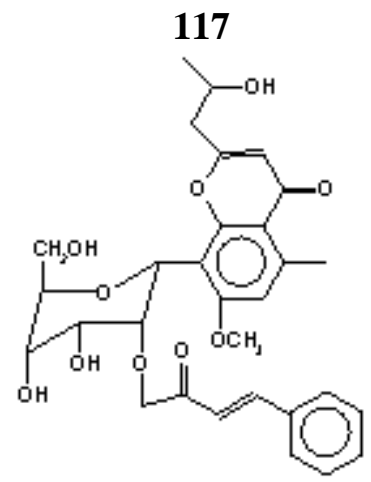

\section{8[C- $\beta$-D-[2-O-(E)-cinamoylglu-copyranosyl]-2-[®-2-hydroxypropyl]-7-methoxy-5- methylchromone}

Found in Aloe barbadensis Mill (Liliaceae). At a dose of $200 \mu$ per mouse ear exhibited topical anti-inflammatory activity equivalent to $200 \mu$ per ear of hydrocortisone[74].

118

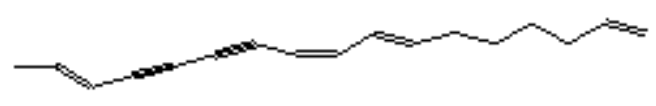

Heptadeca-2E,8E,10E,16-tetraene-4,6-dyne
119

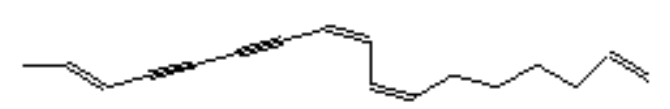

Heptadeca-2E,8Z,10E,16-tetraene-4,6-dyne

\section{0}

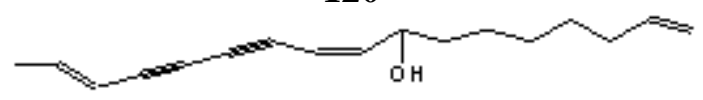

\section{Heptadeca-2E,8E,16-triene-4,6-dyne-10-ol}

Found in Bidens campylotheca Schultz Bip (Compositae). This plant is a traditional remedy in Hawaiian folk medicine for treating general weakness of the body, throat and stomach disorders, and of asthma. Showed significant in vitro inhibition of cyclo-oxygenase (CO) and 5lipoxygenase (5-LO)[75].

121

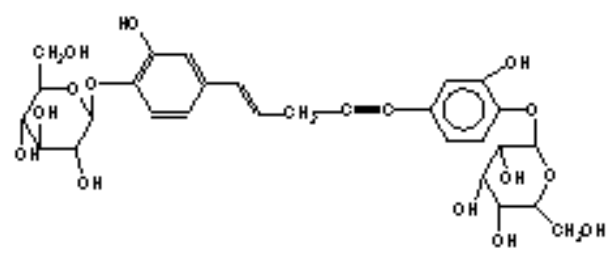

Hypoxoside

Has a pronounced anti-inflammatory (rat paw edema) and fairly good analgesic effect[76]. Isolated from Hypoxis obtusa (Hypoxidaceae) rhizomes. 
122<smiles>COC1C=C(O)CC(/C=C/c2ccccc2)O1</smiles>

Kawain

Occurs in the rhizomes of Piper methysticum (Piperaceae). Has anti-inflammatory activity[77].

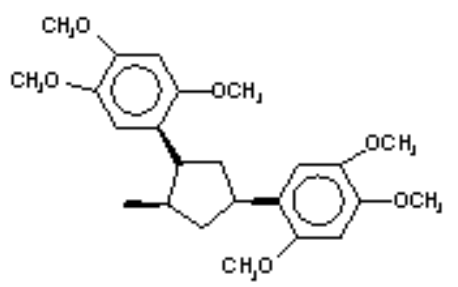

Magnosalicin

Obtained from the dried buds of Magnolia salicifolia (Magnoliaceae), significantly inhibited granuloma tissue formation. The inhibitory effect was particularly strong, being nearly half of hydrocortisone acetate when administered orally[78].

\section{4}

\section{$\mathrm{CH}_{2}(\mathrm{OR}) \mathrm{CH}=(\mathrm{OH}) \mathrm{CH}_{2} \mathrm{OH}$}

\section{Monoglycerides}

The monoglycerides $\mathrm{CH}_{2}(\mathrm{OR}) \mathrm{CH}=(\mathrm{OH}) \mathrm{CH}_{2} \mathrm{OH}$ ( $\mathrm{R}=$ palmitoyl, linoleoyl, linolenoyl, or oleoyl) are isolated from Aconitum chinense (Ranuncolaceae) as analgesic and anti-inflammatories from A. chinense[79].

\section{5}

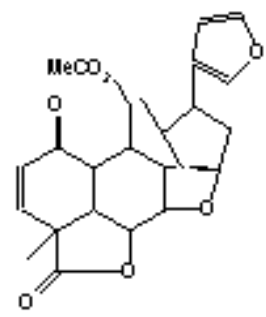

Nimboline

Has pronounced anti-inflammatory (rat paw edema) and fairly good antipyretic effect (pyrogeninduced hyperpyrexia in rabbits). The acute oral toxicity in mice showed a very low range of approximately $13 \mathrm{~g} / \mathrm{kg}$ body weight[80,81]. Isolated from leaves of Rachta indica (Meliaceae). 


\section{Pedilanthain}

A new protease isolated from the latex of Pedilanthus tithymaloides Poit Euphorbiaceae and subjected to anti-inflammatory screening. More potent than phenylbutazone. Exhibits its maximum activity at $2^{\text {nd }}$ hour of its oral administration[82].

\section{7}

\section{Polysaccharide}

Produced by Serratia piscatorum. Exhibited anti-inflammatory activity which was completely lost when hydrolyzed into small molecules[83].

\section{8}

\section{Polysaccharide}

Isolated from Echinocea angustifolia DC. (Compositae). Enhance phgocytosis in vivo an dexhibit anti-inflammatory activity[84].

129

Polysaccharide $M_{t}{ }^{\prime} S 1.5 \times 10^{5}$
130

Polysaccharide $M_{t}{ }^{\prime} S 3.6 \times 10^{4}$

\section{1}

Polysaccharide $\mathrm{M}_{\mathbf{t}}{ }^{\prime} \mathrm{S} \mathbf{1 . 5} \times \mathbf{1 0}^{4}$

Three polysaccharide glucans were isolated from dried roots of Periandra mediterranea Taubert (Leguminosae). Widely used in Brazilian ethnomedicine as a cough suppressant. Highly immunostimulatory[85] and anti-inflammatory properties.

132

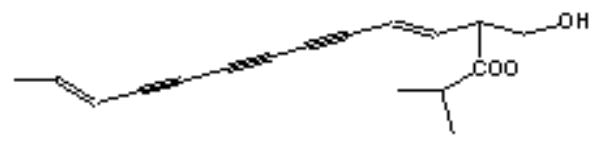

Safynol-2-O-isobutyrate
133

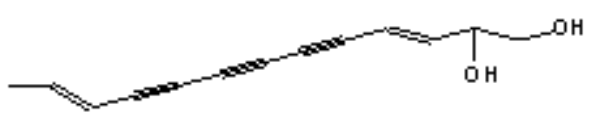

Safynol

Isolated from Bidens campylotheca Schultz Bip (Compositae)[75].

\section{4}<smiles>COC1=C2c3c(c(OC)cc4c(OC)ccc1c34)CN(C)C2O</smiles>

Taspine

Croton lechleri L. (Anacardaceae), commonly called "Sangre de grado", is a tree of the upper Amazon valley of Peru. The bark, when slashed, produces a red viscous sap which is used for the treatment of rheumatism. Shown to elicit anti-inflammatory activity in different models[86]. 
135<smiles>OCC#Cc1ccc(O)c(O)c1</smiles>

Caffeic acid<smiles>O=C1C=CC2C=CC(O)=CC2O1</smiles>

Umbelliferone
136<smiles>COc1c2ccoc2cc2oc(=O)ccc12</smiles>

Bergapten<smiles>CC(C)(O)C1Cc2c(ccc3ccc(=O)oc23)O1</smiles>

\section{Columbianadin}

Caffeic acid, bergapten, columbianadin, and umbelliferone isolated from Angelica pubescens Maxim (Umbelliferae). Significantly demonstrated anti-inflammatory and analgesic activities at $10 \mathrm{mg} / \mathrm{kg}$ in the test: hindpaw, peritoneal vascular permeability, skin window, hot plate, and formalin[87]. The anti-inflammatory and analgesic activities of osthole were reported by Kosuge et al. in 1985[88] from the same plant. Caffeic acid - widespread occurrence in green and roasted coffee beans Coffea arabica, (Rubiaceae), the root bark of Chinchona cuprea, Rubiaceae), and in Conium maculatum (Umbelliferae). Also occurs in herbaceous plants such as Digitalis purpurea (Scrophulariaceae), the leaves and flowers of Papaver sommiferum (Papaveraceae), the roots of Taraxacum officinale, and the flowers of Anthemis nobilis (Compositae) and Achillea millefolium (Compositae)[89]. Umbelliferone - widespread ocurrence in the resin of various Umbelliferae: Ferula, Apium, Pimpinella, and Heracleum spp. Used in sunscreen lotions.

\section{MONOTERPENOIDS, DITERPENOIDS, AND SESQUITERPENOIDS}

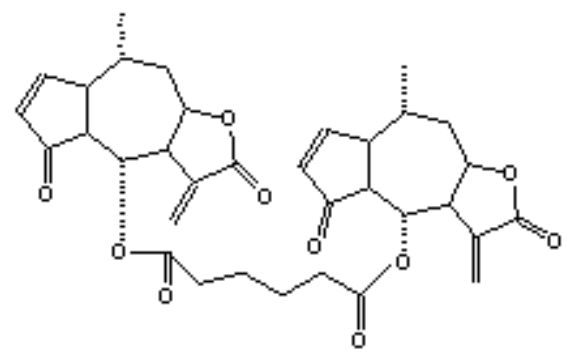

Bis[helenalinyl]adipate

Isolated from Schizogyne sericea (Compositae) leaves. Showed anti-inflammatory activity in rats at $50 \mathrm{mg} / \mathrm{kg}$, i.p. dose[90]. 


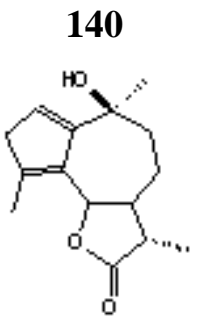

Artabsin

Found in wormwood of Artemisia absinthium (Compositae). Has anti-inflammatory activity[91].

\section{1}

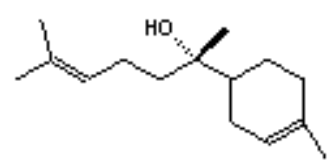

$\alpha$-Bisabolol

Isolated from chamomile oil from Matricaria chamomilla (Compositae). Has anti-inflammatory activity, but is less toxic than guaiazulene, which has a similar action[92].

\section{2}

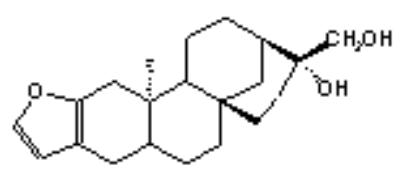

Cafestol

The main constituent of the unsaponifiable portion of coffee bean oil. From Coffea spp. (Rubiaceae). Showed anti-inflammatory activity against carrageenan-induced edema in rats[93].

\section{3}

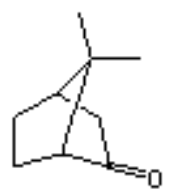

\section{Camphor}

Constituent of Matricaria parthenium (Compuestas). Has a pronounced anti-inflammatory activity in rat paw edema[94].

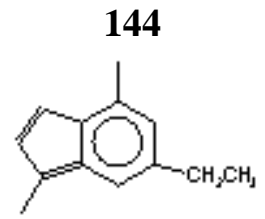

\section{Chamazuleno}

A blue oil produced during steam distillation of chamomile with anti-inflammatory and antipyretic activities[92]. Isolated from leaves of Matricaria chamomilla (Compositae). 


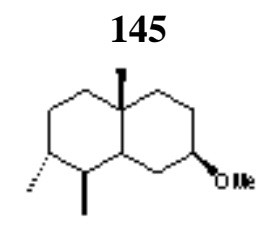

\section{Chrysanthemol}

A new compound isolated from Crysanthemun indicum L. (Compositae) flowers that showed strong anti-inflammatory activity in mice[95].

146

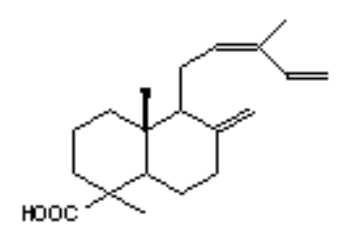

Cis-communic acid

Found in Cryptomeria japonica Don (Taxodiaceae). Has anti-inflammatory activity. The activity testing was done using the carrageenan-induced paw edema (CPE) method in rats[96]. The leaves of $C$. japonica have been used traditionally in Chinese medicine for the treatment of eczema, eruption, and swelling injury by topical application. Cis-communic acid showed antiinflammatory effect when applied topically to rats and an inhibitory effect on histamine-induced ileum contraction[86].

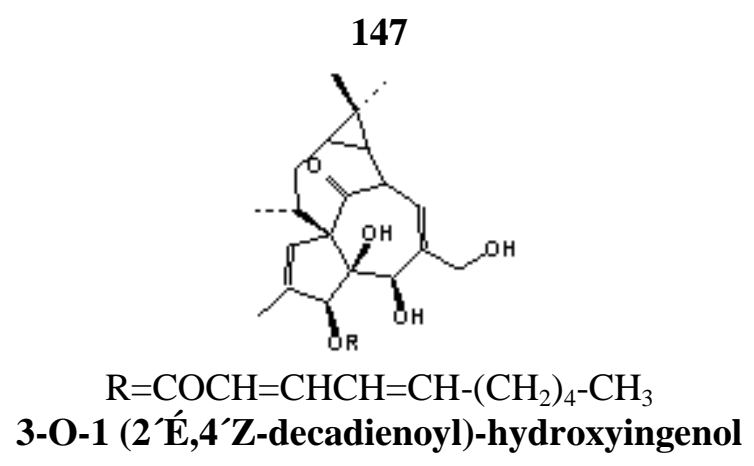

148

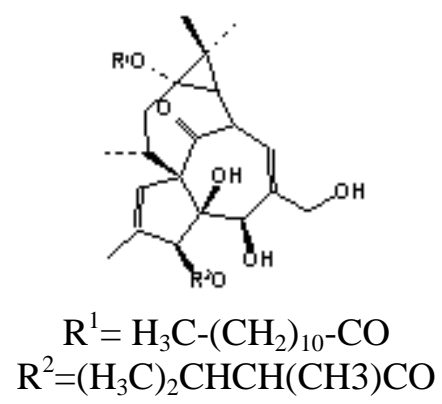

\section{3-O-(2,3-dimethylbutyryl)-13-O-n-dodecanoyl-13-hydroxyingenol}

Immune complex binding to macrophages was enhanced by treatment with a Euphorbia kansui Liou (Euphorbiaceae) extract. Systematic fractionation of the extract led to the characterization of 3-O-1(2’É,4`Z-decadienoyl)-hydroxyingenol and 3-O-(2,3-dimethylbutyryl)-13-O-n-dodecanoyl13-hydroxyingenol as the active principles. Immune complex binding to macrophages by the action of these compounds increased in a dose-dependent manner[97]. 


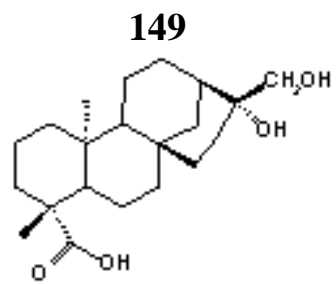

\section{Diterpenoid SP-II}

Found in Sigesbeckia pubescens (Compositae) together with several other related diterpenoids. Showed anti-inflammatory activity and is a powerful antihypertensive[93].

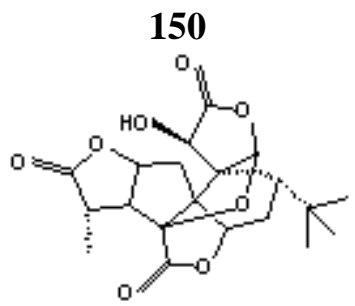

Ginkgolide A

Found in the root bark and leaves of maidenhair tree, Ginkgo biloba (Ginkgoaceae). Used medicinally to treat allergic inflammation and asthma[91].

151

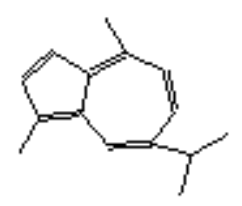

Guaiazulene

A blue oil produced during steam distillation of chamomile with anti-inflammatory and antipyretic activities[92]. Extracted from Matricaria chamomilla (Compositae).

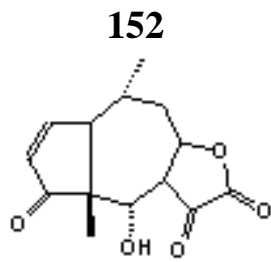

\section{Helenalin}

Sesquiterpene lactones have previously been shown to possess anti-inflammatory and antiarthritic activities in rodents. The $\alpha$-methylene- $\gamma$-lactone moiety of this chemical class is required for activity as well as the $\beta$-unsaturated cyclopentenone ring. The helenalin showed significant inhibitory activity against carrageenan-induced edema[90]. Isolated from Helenium autumale, $H$. anaphalis, H. balduinea, and H. gaillardia (Compositae). 


\section{3}

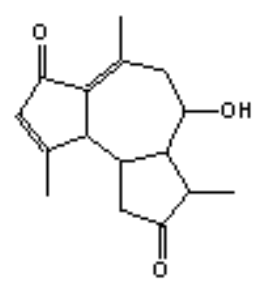

\section{Hydroxyachillin}

Found in the aerial parts of Tanacetum microphyllum (Compositae). Used in the Iberian peninsula since ancient times in Spanish traditional medicine as an anti-inflammatory and antirheumatic agent, and for its beneficial effects on the digestive tract. Showed a marked anti-inflammatory activity in carrageenan-induced paw edema in mice[98].

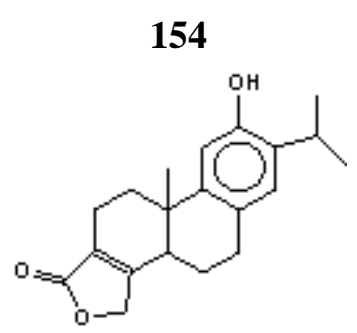

\section{Isotriptophenolide}

An abietane diterpene from the perennial herb Tripterygium wilforddi Hookf. (Celastraceae). Shown to possess anti-inflammatory activity[99]. Has gastric cryoprotective effect[100].

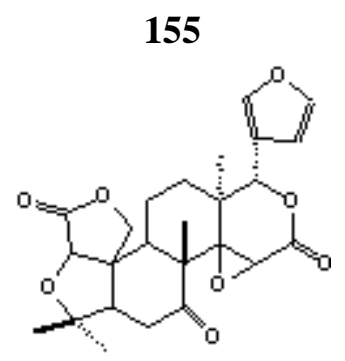

\section{Limonin}

Possesses an antinociceptive effect accompanied by an anti-inflammatory action. Isolated from Evodia rutaecarpa var. Bodinieri (Rutaceae)[101].

\section{6}

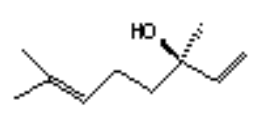

\section{Linalool}

The main constituent of oil coriander from Coriandrum sativum (Umbelliferae) and Thymus quinquicostatus. Exhibits anti-inflammatory action[102]. 


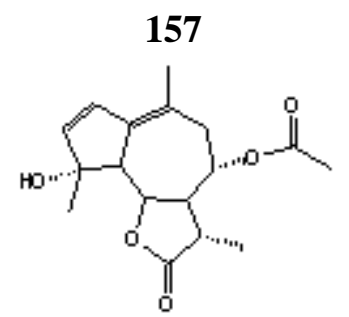

\section{Matricin}

The guaianolide was isolated from chamomile, Matricaria chamomilla (Compositae). Precursor of chamazulene, which is anti-inflammatory[91].

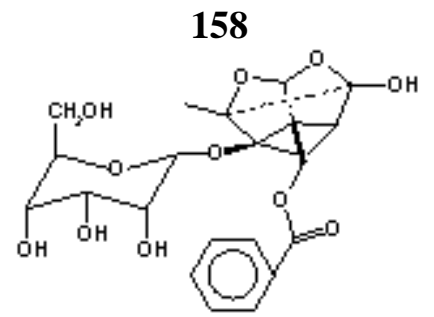

Paeoniflorin

Found in Paeonia lactiflora (Paeoniaceae). Has anti-inflammatory activity[103].

159<smiles>CC1(C)CCCC2(C)C3=C(CCC(=CCO)C3)C(O)CC12</smiles>

\section{Rhinocerotinoic acid}

The structure was determined as 7-oxolabda-8-13-dien-15(E)-oic acid by means of X-ray. Showed anti-inflammatory activity in rats[104]. Isolated from leaves of Elytropappus rhinocerotis.

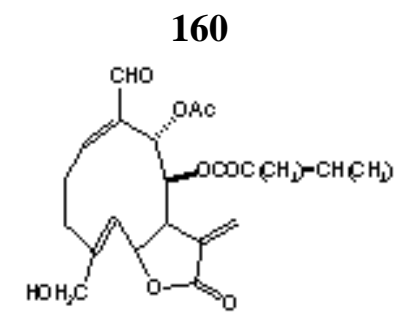

\section{Sesquiterpene}

Isolated from Siegesbeckia pubescens (Asteraceae) leaves at $100 \mathrm{mg} / \mathrm{kg}$ p.o. Inhibited inflammation by $44.9 \%$ in the carrageenan edema test using male Wistar rats[105].

161

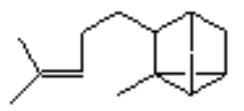

$\beta-$ Santalen

Anti-inflammatory activity of the petroleum ether extract of Conzya canadensis L. Cronq (Asteraceae) has been reported. The fractionation of the extract led to the isolation of five 
sesquiterpenes: $\beta$-santalen, $\beta$-himachalen, cuparene, $\alpha$-curcumene, $\gamma$-cardinene with antiinflammatory activity[106].

162

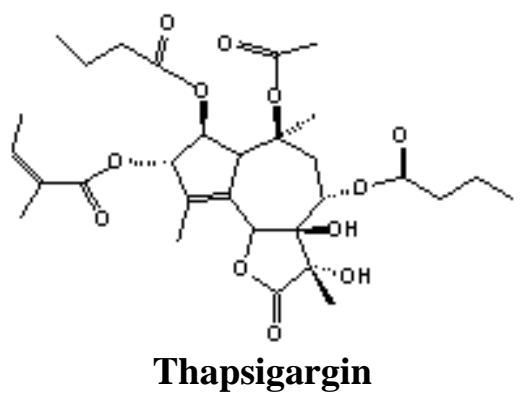

Found in Thapsia garganica (Umbelliferae). Potent activator of cells involved in antiinflammatory response[91].

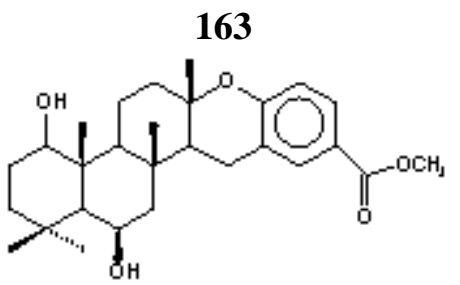

Tolypodiol

The diterpenoid has been isolated from the terrestrial cyanobacterium, Tolypothix nodosa (HT58-2). Shows potent anti-inflammatory activity in the mouse ear edema assay[107].

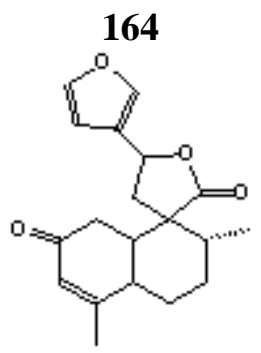

\section{Trans-dehydrocrotonin}

Occurs in Croton cajucara Benth. (Euphorbiaceae). Widely known in traditional phytotherapy for the treatment of diabetes, diarrhea, gastrointestinal disorders, and liver diseases. Also indicated for controlling high cholesterol levels. Its vernacular name is sacasa and it occurs widely in the Amazon region (Brazil). Produced a significant inhibition of carrageenan-induced paw edema and cotton pellet granuloma in rats. It also inhibited the writhing in mice induced by acetic acid[108].

165<smiles>C=C[C@]1(C)C=C2CC[C@H]3C(C)(C)C[C@H](O)[C@@H](O)[C@]3(C)[C@H]2CC1</smiles>

$2 \alpha$-Acetoxysandaracopimaradien-1 $\alpha$-ol
166<smiles>C=C[C@]1(C)C=C2CC[C@]3(C)C(C)(C)C[C@@H](O)[C@H](O)C3(C)C2CC1</smiles>

The two diterpenes isolated from Kaempferia pulchra Ridl. (Zingiberaceae) have been assayed for topical anti-inflammatory activity in the model of TPA-induced ear edema in rats[109]. 


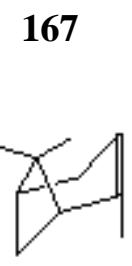

$\alpha$ Pinene
168

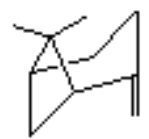

$\beta$ Pinene
169<smiles>Cc1ccc(C(C)C)c(O)c1</smiles>

Thymol
170<smiles>Cc1ccc(C(C)C)cc1O</smiles>

Carvacrol

The essential oil of Bupleurum fructicosum L. (Umbelliferae) has shown significant antiinflammatory activity in carrageenan-induced rat paw edema model and the activity is attributed in part to the major components, $\alpha$ and $\beta$ pinene. It has also been shown that thymol and carvacrol, although present in extremely low levels, potentiate the pharmacodynamic action[106].

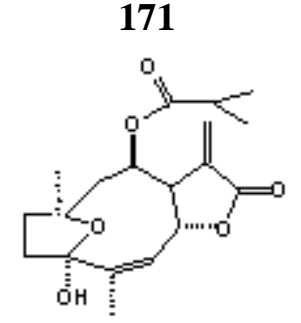

Tirotundin

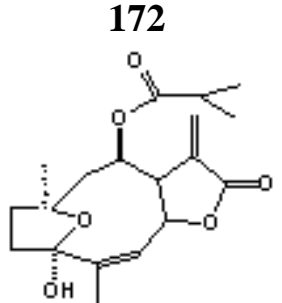

Diversifolin

Sesquiterpene lactones from Tithonia diversifolia (Hemsl) A. Gray (Asteraceae). In Central America, leaf extracts from this plant are used for the treatment of hematomas and wounds. Inhibit cyclo-oxygenase 1, phospholipase $\mathrm{A}_{2}$, or the transcription factor NF-KB[110].

173<smiles>CC/C=C\C(C)(C)C/C=C(/C)CCCCC</smiles>

$\beta$-Humulene
174<smiles>CC(C)C1CCC2(C)CCCC1C2(C)C</smiles>

$\alpha$-Copaene
175

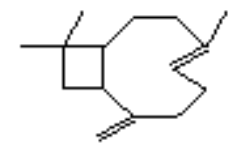

$\beta$-Caryophyllene

Copaiba oleoresina from Brazilian Copaifera spp. (Leguminosae). Has a widespread use in popular medicine as an anti-inflammatory agent. The oral administration of the oleoresin inhibited the development of carrageenan-induced edema in rats in dose-dependent manner. The oleoresin showed the presence of copalic acid and sesquiterpenes like $\beta$-bisabolene, $\beta$ caryophyllene, $\beta$-cubelene, aromandrene, $\beta$-humulene, and $\alpha$-copaene[106,111].

176<smiles>CCC1CCCC(C)C1C1OC(=O)C(C)C1[C@H](O)[C@H](O)C(C)C</smiles>

177

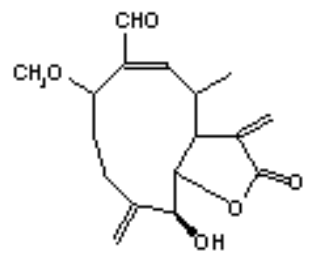

1ß-Methoxymiller-9Z-enolide

$8 \beta$-Hydroxy-9 $\alpha$-methacryloyloxy14-oxo-acanthospermolide 
178

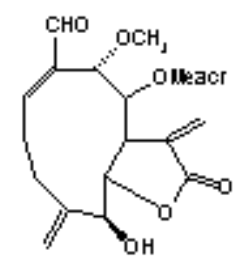

9 $\alpha$-Methoxymiller-1-(10)-Z-enolide
179

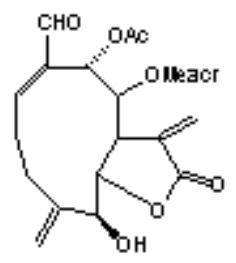

9 $\alpha$-Acetoxymiller-1-(10)-Z-enolide

180

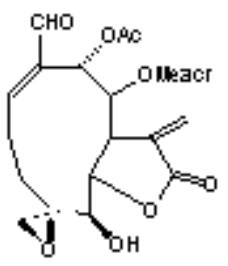

\section{9 $\alpha$-Acetoxy-4 $\beta, 15$-epoxymiller-1-(10)-Z-enolide}

In Central America, aerial parts of the Milleria quinqueflora (Asteraceae) are used in traditional medicine as a remedy for skin infections. All sesquiterpene lactones have anti-inflammatory activity using transcription factor NF-kB as molecular target. This is involved in the synthesis of inflammatory mediator, such as cytokines and chemokines. NF-kB -DNA binding was inhibited at micromolar concentrations by all compounds[112].

181<smiles>C=C1CCCC2(C)CCC(C(C)(C)O)CC12</smiles>

$\beta$-Eudesmol
182<smiles>C=C1C(=O)OC2C1CCC1(C)C(O)CCC(=C)C21</smiles>

Reynosin
183<smiles>C=C1C(=O)OC2C1CCC1(C)CCC=C(C)C21</smiles>

$\alpha$-Cyclocostunolide
184<smiles>COc1cc([C@H]2O[C@H](c3ccc(O)c(OC)c3)C(C)C2C)ccc1O</smiles>

Nectandrin-B
185<smiles>COc1cc(O)c(OC)c([C@@H]2OCC3C2CO[C@H]3c2cc(OC)c(O)c(OC)c2)c1</smiles>

Syringaresinol

Found in Tsoongiodendron odorum and Manglietiastrum sinicum (Magnoliaceae). Displayed considerable inhibition against platelet aggregation induced by arachidonic acid (AA), adenosine diphosphate (ADP), and revealed inhibition activity against PAF-induced platelet aggregation[113]. 


\section{PHENOLICS COMPOUNDS}<smiles>COc1c(O)cc2c(c1O)C1OC(C)[C@H](O)[C@H](O)[C@H]1CC2=O</smiles>

\section{Bergenin}

Occurs in Peltophorum pteracarpum, P. inerme, Caesalpinia digyna (Leguminosae), Ardisia hortorum, Astilbe macroflora, Bergenia crassifolia (Saxifragaxeae), Corylopsis spp. (Hamamelidaceae), and Humuria balsamifera (Humiriaceae)[77]. Found to be equipotent to phenylbutazone in rats against carrageenan-induced edema.

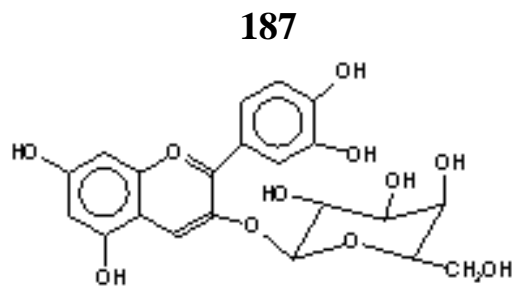

\section{Cyanidin-3-O-galactoside}

Has anti-inflammatory activity and is used in the prevention of capillary fragility[114]. Isolated from leaves of Fagus sylvatica (Fagaceae).

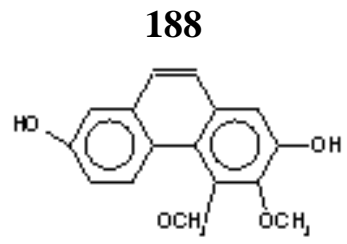

\section{2,7-Dihydroxy-3,4-methoxyphenantreno}

Showed inhibitory effect on contraction of guinea pig ileum induced histamine, while the topical application showed inhibition of edema in carrageenan-induced rat paw edema model[46]. Isolated from leaves of Catastum barbatum Lindl. (Orchidaceae).

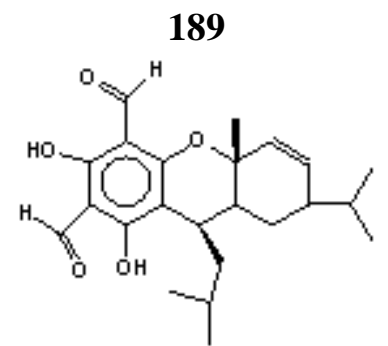

\section{Euglobal-1 ${ }^{a}$}

Showed granulation inhibitory activity. One of a series of related compounds from Eucalyptus globulus (Myrtaceae) having the same activity[115]. 


\section{0}

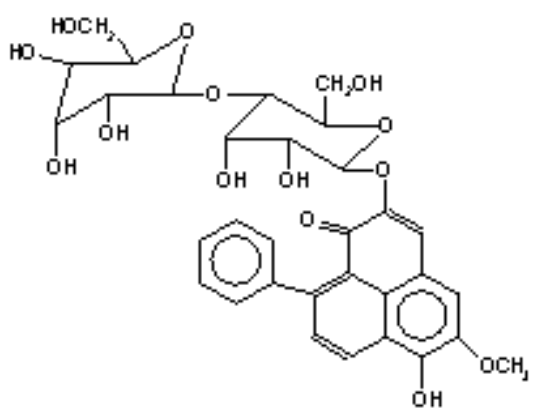

\section{Haemocorin}

Found in Haemodorum coxymbosum (Haemodoraceae). This aglycone showed anti-inflammatory activity[115].

191

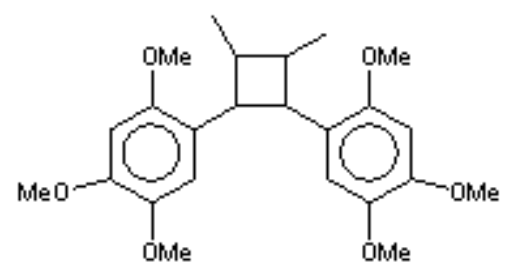

Magnosalin
192<smiles>CC1=Cc2c(O)cc(O)c(O)c2[C@H](c2cc(O)c(O)cc2O)C1C</smiles>

Magnoshinin

Found in Magnolia salicifolia (Magnolaceae). Possess inhibitory effects on granuloma formation[116].

\section{3}<smiles>CC(=O)c1ccc(C)cc1O</smiles>

Paenol

Obtained from the traditional Chinese drug, Mu-San-Pi. Has bacteriostatic, anti-inflammatory, and CNS depressive effects[117]. Isolated from Paeonia suffruticosa Andr. (Paeoniaceae) roots.

194<smiles>O=C(O)c1ccc(O)c(O)c1</smiles>

Protocatechuic acid

Found in Erica australis (Ericaceae). Has anti-inflammatory activity[46]. 
195<smiles>CC(=O)c1c(C)c(O)c2c(c1C(C)=O)OC1=CC(=O)C(C(C)=O)C(=O)C12C</smiles>

Usnic acid
196<smiles>Cc1cc(O[N+](=O)[O-])c(C)c(O)c1C(=O)c1cc(C)c(C(=O)O)c(O)c1C</smiles>

Diffractaic acid

The active principle usnic and diffractaic acid isolated from Usnea diffracta Vain (Usneaceae) exhibited anti-inflammatory activity when administered a dose of $50 \mathrm{mg} / \mathrm{kg}$. Significantly inhibited the granulation tissue formation induced by subcutaneous implantation of cotton pellet[24].

197

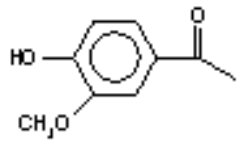

\section{Vanillic acid}

Occurs in Fagara spp. (Rutaceae), Alnus japonica (Betulaceae), Eleagnus pungens (Eleagnaceae), Erica australis (Ericaceae), Gossypium mexicanum (Malvaceae), Melia azedarach (Meliaceae), Panax ginseng (Araliaceae), Patecoma koraiensis (Bignoniaceae), Pterocarpus santalinus, Rosa canina (Rosaceae), Picrorhiza kurroa (Scrophulariaceae). and Trachelospermum asiaticum (Umbelliferae). The vanillic acid in vitro test indicated antiinflammatory activity[46].

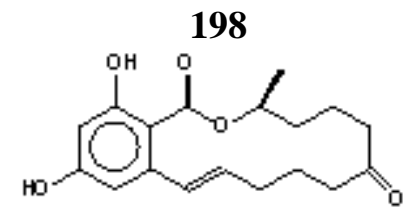

Zearalenone

A mycotoxin of fungus Gibberella zeae, which infects maize. Caused significant dose-dependant inhibition of carrageenan-induced paw edema[115].

199<smiles>Oc1ccc2c(c1)OCC1(O)Cc3cc(O)c(O)cc3C21</smiles>

Hematoxylin
200<smiles>[2H][C@@]12Cc3cc(O)c(O)cc3C(C1)c1ccc(O)cc1O2</smiles>

Brazilin

Brazilin together with hematoxylin, a constituent of Haematoxylon campechianum Linn. and Caeselpinia sappan Linné (Leguminosae) wood, have been subjected to various antiinflammatory assays. Both substances proved to exhibit significant anti-inflammatory activities in the carrageenan-induced rat paw edema test and the fertile egg test[118]. 
201<smiles>CCCCCc1cc(O)c2c(c1)OC(C)(CCCC(C)(C)C)C=C2</smiles>

Cannabichromene
202

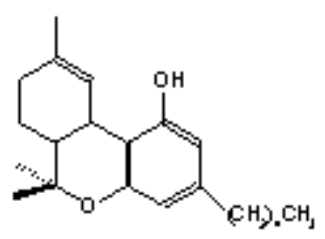

$\Delta^{1}$-Tetrahydrocannabinol (Dronabinol)

Cannabichromene has anti-inflammatory activity[77]. $\Delta^{1}$-Tetrahydrocannabinol, the active principle of marihuana, has anti-inflammatory, antiemetic, and hallucinogenic properties. Used topically in hypertensive glaucoma[119]. Isolated from Cannabis sativa (Cannabaceae) leaves.

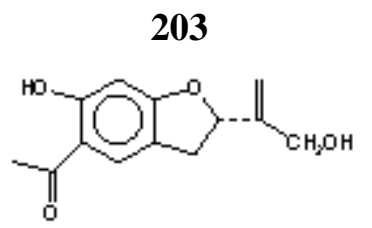

\section{Tremetone}

204<smiles>CC(=O)c1ccc(O)c(C(=O)C=C(C)C)c1</smiles>

Non-benzofuran acetophenone 1
205<smiles>CC(O)c1ccc2c(c1)C(=O)CC(C)(C)O2</smiles>

Isolated from Ophyosporus axilliflorus Griseb. (Asteraceae). Exhibited anti-inflammatory activity on carrageenan-induced mouse paw edema[120].

206<smiles>Cc1oc(=O)c2c(O)cc(O)cc2c1C</smiles>

6,8-Dihydroxy-3,4-dimethyl-

\section{H-2benzopyran-1-one}

Found in the roots of Polygonum hydropiper (Polygonaceae). Has anti-inflammatory<smiles></smiles>

\section{Polygonolide}


208<smiles>Oc1ccc(C2OC(c3ccc(O)cc3)c3c2cc(O)cc3C2c3cc(O)cc4c3C(c3cc(O)cc5c3C4C(c3ccc(O)cc3)O5)C2c2ccc(O)cc2)cc1</smiles>

Vineferin
209<smiles>Oc1ccc(C=C[C@H]2C[C@H](O)C3=C2[C@H](c2cccc4c2C(c2cc(O)cc(O)c2)C(c2ccc(O)cc2)O4)C(c2ccc(O)cc2)C3)cc1</smiles>

Miyabenol

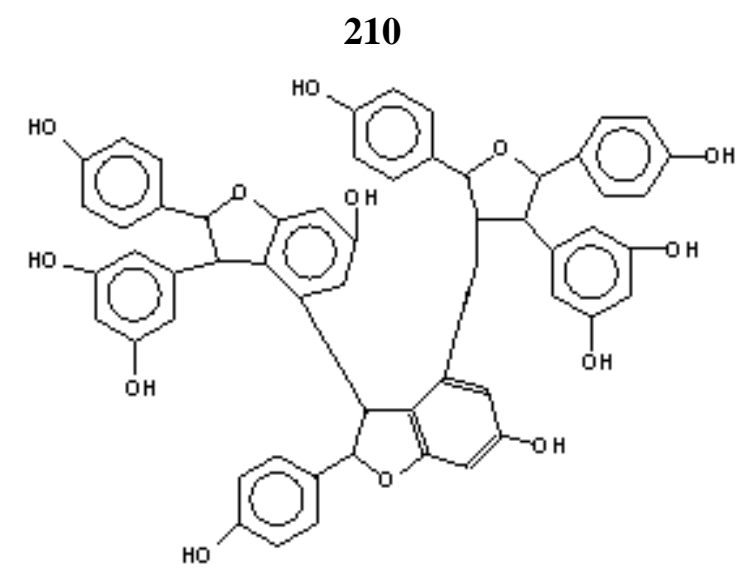

\section{Kobophenol}

These oligomeric stilbenes have been isolated from Caragana sinica (Buchoz) (Leguminosae). Exhibited protein kinase $\mathrm{C}$ inhibitory activity at low micromolar concentrations[122].

211<smiles>CC(C)=CC1C[C@H](C)C2CC[C@H](C)C3=C(O)[C@H](O)C(C)CC32C1</smiles>

\section{8,10,12,14-Epiamphilectatetraene-9,10-diol}

A constituent of Pseudopteregorgia elisabethae and has anti-inflammatory activity[121]. 


\section{PHENYLPROPANOIDS}

212<smiles>CC12CC3CC(C1)C(C)(C3)[C@H]2OC(=O)/C=C/c1ccc(O)cc1</smiles>

(-)-Bornyl p-coumarate
213

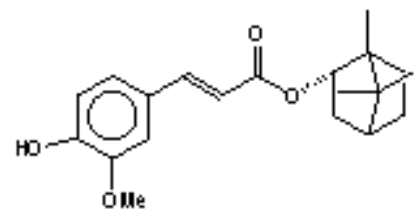

(-)-Bornyl ferulate
214<smiles>CC12CC3CC(C1)C(OC(=O)/C=C/c1ccc(O)c(O)c1)C3C2</smiles>

(-)-Bornyl caffeate

Isolated from the roots of Coreopsis mutica var. Mutica (Compositae). Have anti-inflammatory activity[123].

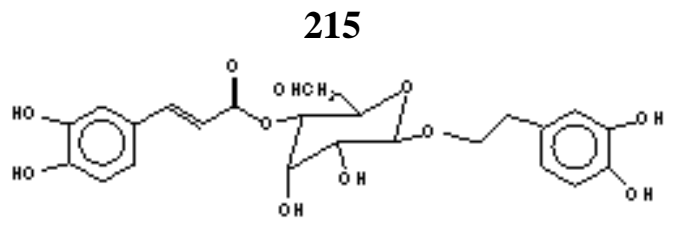

Calceolarioside A

Found in Calcolaria hypericina Poepp. (Scrophulaiaceae). Has anti-inflammatory activity[124].

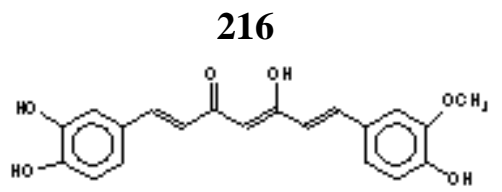

\section{Curcumin}

A constituent of turmeric. Has been shown to be an effective anti-inflammatory agent. As potent as phenylbutazone in the carrageenan edema test but half as potent in chronic tests. The mechanism of anti-inflammatory activity is found to be multifactorial. Inhibited lysosomal enzymes (acid phosphatase and cathepsin D) and was effective in inhibiting lipid peroxide formation[89]. Has cytotoxic and antioxidant activities. Reduces cholesterol level and helps control blood sugar. Isolated from rhizomes of Curcuma longa, $C$. aromatica, and $C$. xanthorrhiza (Zingiberaceae).<smiles>CC(C)CNC(=O)/C=C/c1ccc2c(c1)OCO2</smiles>

\section{Fagaramide (piperonyl-4-acrylicisobutylamide)}

Effective against carrageenan paw edema in rats and was approximately 20 times less potent than indomethacin. Effective against the prostaglandin phase of an acute experimental inflammatory reaction. It is thus suggested that at least part of the anti-inflammatory activity of fagaramide is mediated via inhibition of prostaglandin synthesis[125]. The roots of Zanthoxylum zanthoxyloides and Fagara xanthoxyloides (Rutaceae) have been used to treat allergic and anti-inflammatory diseases. The activity is due a fagaramide, a phenylpropanoid, that inhibits the edema of the rat paw induced by carrageenan[89]. 


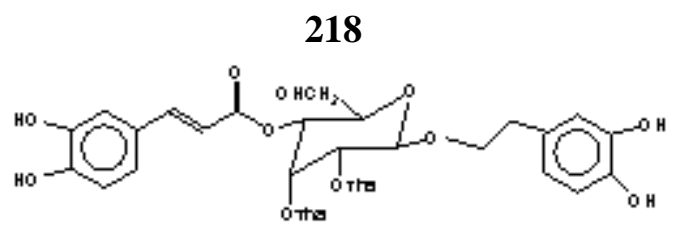

Forsythoside

Occurs in Calcolaria ascendens Lind. (Scrophulaiaceae). Has anti-inflammatory activity and enhanced production of cyclo-oxygenase products[124].

219<smiles>O=C(O)/C=C/c1ccc(O)c(O)c1</smiles>

Isoferulic acid

Obtained from the crude extract of Cimicifuga dahurica Maxim. Ranunculaceae rhizomes reduce carrageenan-induced edema[106].

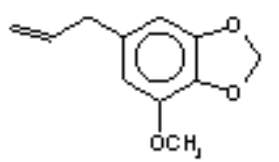

Myristicin

The fruit of Myristica fragrans Houtt (Myristacaceae) has been used in Indonesian folk medicine as aromatic stomachics, analgesics, and a medicine for rheumatism. The anti-inflammatory activity in carrageenan-induced edema in rats and vascular permeability in mice is due to the major principle myristicin[126].

221

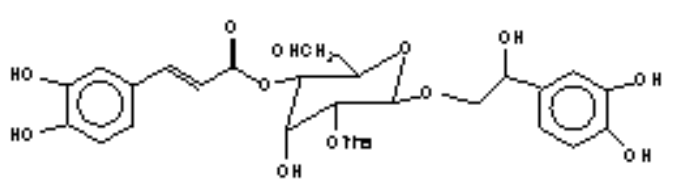

Orobanchoside

Occurs in Orobanche hederae Duby (Orobanchaceae). Inhibited the formation of 5-lipoxygenase product 5-HETE[124].

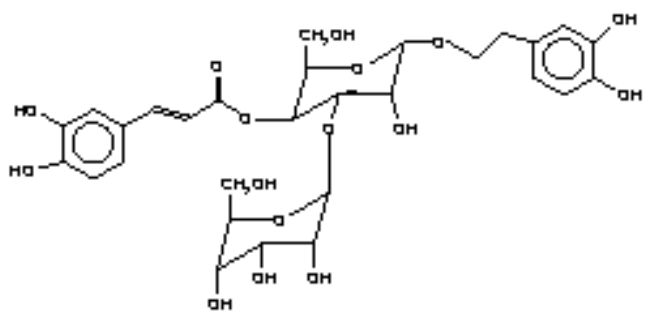

\section{Plantamajoside}

Occurs in the leaves of Plantago major and P. asiatica (Plantaginaceae). Inhibits 5-lipoxygenase and cyclic adenosine monophosphate diesterase, thus explaining the anti-inflammatory activity of Plantago plants[89]. 


\section{3}

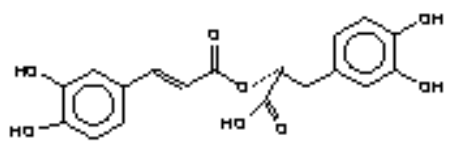

\section{Rosmarinic acid}

Occurs within the Labiatae in Rosmarinus officinalis, Salvia officinale, Melissa officinalis, Menta piperita, and Teucrium scorodonia. Also occurs in Symphytum officinale (Boraginaceae), in some Hydrophyllaceae and Acanthaceae, and in the genera Anethum, Levisticum, Sanicula, and Astrantia (Umbelliferae). Has anti-inflammatory activity[48].

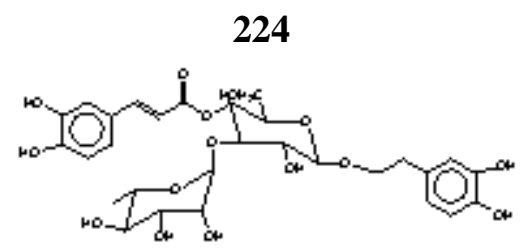

\section{Verbacoside}

The anti-inflammatory activity has been demonstrated on the exudative and proliferative phases of cotton pellet granuloma[48]. Isolated from leaves of Buddleja globosa and A. officinalis (Scrophulariaceae).<smiles>COc1cc(CCC(=O)CCc2ccc(O)c(CO)c2)ccc1O</smiles>

\section{1,5-Bis(4-hydroxy-3-methoxyphenyl)-(1E.4E)-1,4-pentadien-3-one}<smiles>O=C(CCc1ccc(O)cc1)CCc1ccc(O)c(CO)c1</smiles>

\section{1(4-Hydroxy-3-methoxyphenyl) 5-(4-hydroxyphenyl)-(1E.4E)-1,4-pentadien-3-one}<smiles>Cc1cc(/C=C/C(=O)CC(=O)/C=C/c2ccc(O)cc2)ccc1O</smiles>

\section{Demethoxycurcumin}


228<smiles>O=C(/C=C/c1ccc(O)cc1)CC(=O)CCc1ccc(O)cc1</smiles>

Bisdemethoxycurcumin
229<smiles>C/C=C/C(=O)CC(=O)/C=C/c1cc(OC)c(O)c(OC)c1</smiles>

5'-Methoxycurcumin

Isolated from rhizomes of Curcuma domestica (Zingiberaceae). Showed anti-inflammatory activity[127].

\section{QUINONES}

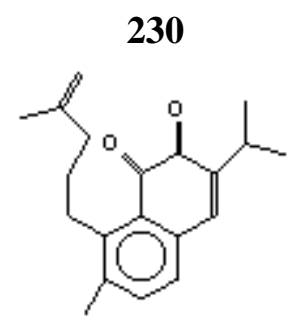

\section{Aethiopinone}

An o-naphthoquinone diterpenoid isolated from Salvia aethiopis L. (Labiatae) roots. Commonly used in folk medicine for a wide variety of remedies. Exhibited sizeable antinociceptive and antiinflammatory effects in rodents. Produced a strong anti-inflammatory effect on an acute inflammatory process like that induced by carrageenan, which was in the same order of magnitude as that observed after poroxicam or ibuprofen administration and its antinociceptive effects were specially important against thermal painful stimuli[128].

231<smiles>COc1cc2c(cc1OC)OCC(C1CC(=O)C(OC)C(OC)C1=O)C2</smiles>

Abruquinones A

233<smiles>COc1cc2c(c(OC)c1O)OCC(C1CC(=O)C(O)C(C(C)O)C1=O)C2</smiles>

Abruquinones D
232<smiles>COc1cc2c(c(OC)c1OC)OCC(C1CC(=O)C(OC)C(OC)C1=O)C2</smiles>

Abruquinones B

234<smiles>CCOC1C(=O)C(O)C(C2COc3c(cc(OC)c(OC)c3OC)C2)C(=O)C1OC</smiles>

Abruquinones E 


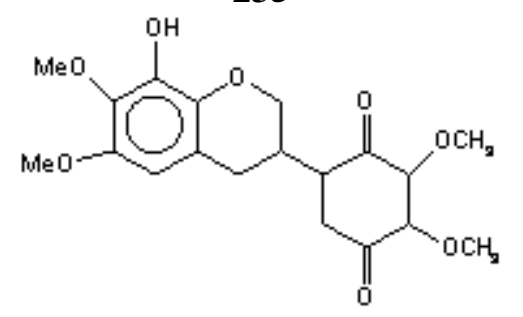

Abruquinones F

The pharmacological activities of the five isoflavanquinones isolated from the leaf of Abrus precatorius $\mathrm{L}$. (Leguminosae) have been evaluated. The results indicate that abruquinones A, B, and $\mathrm{D}$ exhibited remarkable inhibitory effects on the platelet aggregation. The compounds $\mathrm{A}, \mathrm{B}$, $\mathrm{D}$, and $\mathrm{F}$ showed strong anti-inflammatory and antiallergenic effects. The IC50 of abruquinones $\mathrm{A}, \mathrm{B}, \mathrm{D}$, and $\mathrm{F}$ for the inhibition of superoxide formation were less than $0.3 \mu \mathrm{g} / \mathrm{ml}$ for the inhibition of the release of both $\beta$-glucuronidase and lysosyme from rat neutrophils[129]. This plant is used as a folk-medicine in China for the treatment of laryngitis, hepatitis, and bronchitis, indicating that it exhibits anti-inflammatory activity.

\section{6}<smiles>CC1=CC(C)C(=O)c2cc(C)ccc21</smiles>

\section{Chimaphillin}

Anti-inflammatory and analgesic principles were isolated from the methanol extract of the whole herb of Pyrola rotundifolia L. (Pyrolaceae). Based on bioassays of the inhibitory activities on carrageenan-induced hindpaw edema in rats on acetic acid-induced writhing in mice. The principles were identified as ursolic acid and chimaphillin[88]. P. rotundifolia is found in the group of Chinese crude drugs called Qu-feng-shi-yao, which has long been used as a remedy mostly for arthritic diseases in traditional Chinese medicine.<smiles>O=C(O)c1cc(O)c2c(c1)C(=O)c1c(O)cccc1C2=O</smiles>

\section{4,5-Dihydroxyanthraquinone-2-carboxilic acid}

Possesses anti-inflammatory activity in carrageenan-induced paw edema. Isolated from Rheum palmatum leaves[121].

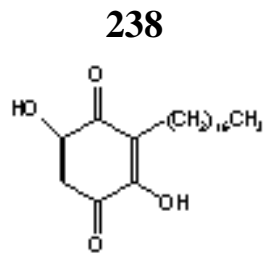

Embellin 
Possesses anti-inflammatory activity in carrageenan-induced paw edema and cotton pellet granuloma formation[130]. Isolated from Embelia ribes Burm (Myrsinaceae) leaves.

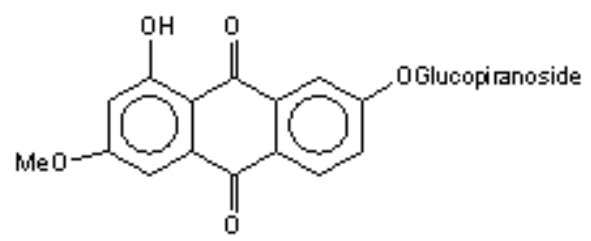

\section{8-Hydroxy-6-methoxy- 2 methylanthra-quinone-3-O- $\beta$-D-glucopyranoside}

Isolated from Limonia crenulata Roxb. (Rutaceae). Showed significant inhibition (65.9\%) of carrageenan-induced paw edema in rats in a dose of $1 \mathrm{~g} / \mathrm{kg}[131]$.

240<smiles>CC(C)CC[C@H](O)C1=CC(=O)c2c(O)ccc(O)c2C1=O</smiles>

Shikonin
241<smiles>COc1ccc(OC(C)=O)c2c1C(=O)C=C(C(CC=C(C)C)OCc1ccccc1)C2=O</smiles>

Acetylshikonin

Shikonin and acetylshikonin are active ingredients in the traditional Chinese drug Zi-Cao (Arnebia euchroma Royle, Boraginaceae). Both of these compounds inhibit the usual increase of capillary permeability induced in rats by histamine and have significant anti-inflammatory effects in rats on edema of the paws induced by acute exposure to formalin[132].

\section{TRITERPENOIDS AND STEROIDS}

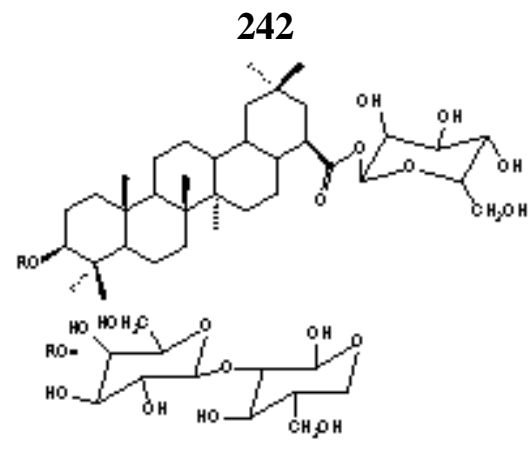

Arvenoside A

A triterpenoid saponin that showed strong anti-inflammatory activity[133,134]. Isolated from Calendula arvensis (Compositae) leaves. 


\section{3}

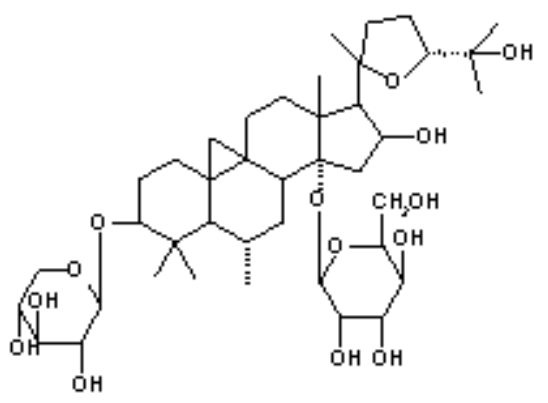

Astramembrannin

Isolated from Huang-Qi (the traditional Chinese drug plant Astragalus membranaceus Bge). Has anti-inflammatory action[135].

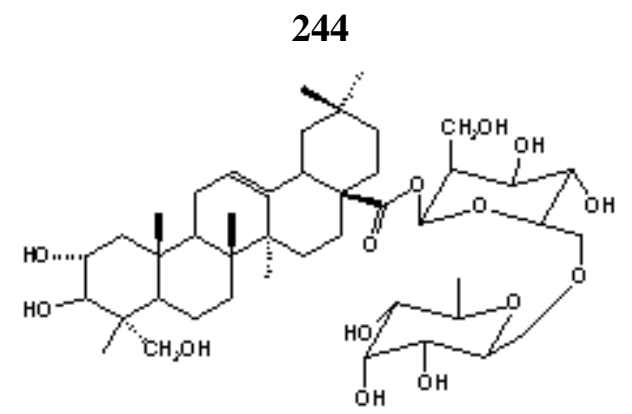

Asteryunnanoside A

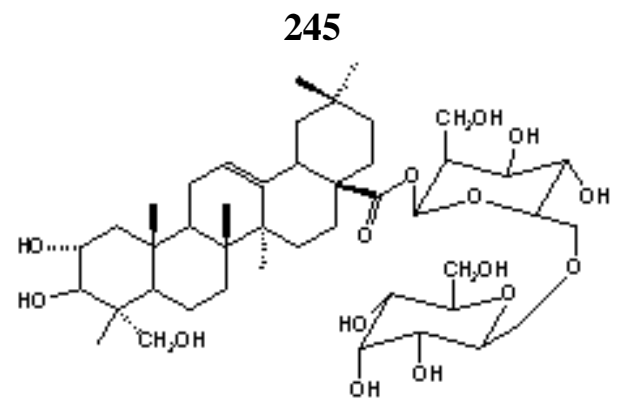

Asteryunnanoside B

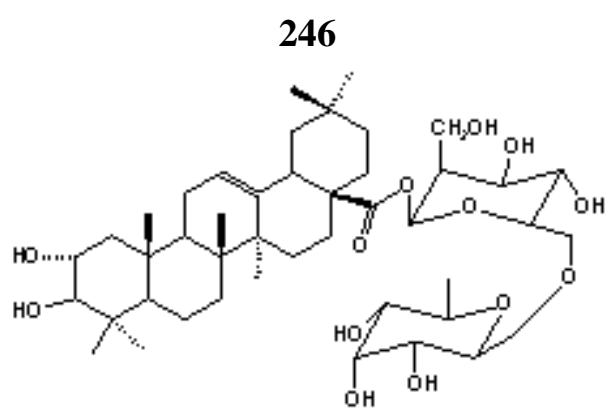

Asteryunnanoside C

Found in Aster yunnanensis (Compositae). Used as drug for the treatment of fevers, colds, tonsillitis, snake bites, and bee stings in Chinese medicine. Showed potent analgesic and antiinflammatory activity[136].

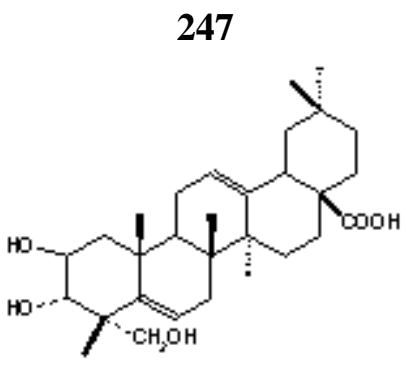

Bassic acid 
Isolated from the ethanol extract of Bumelia sartorum Mart. (Sapotaceae) leaves and has been shown to be responsible for anti-inflammatory activity[133].

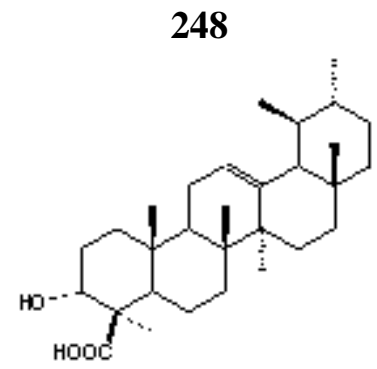

Boswellic acid

In India, the oleogum resin of Boswellia serrata Roxb. Ex Coleb (Burseraceae) has been released for therapeutic use under trade name "Sallaki" for the treatment of rheumatism and nervous diseases. It has been established that anti-inflammatory and antiarthritic activities are due to the presence of boswellic acid and other related pentacyclic triterpene acids[137].

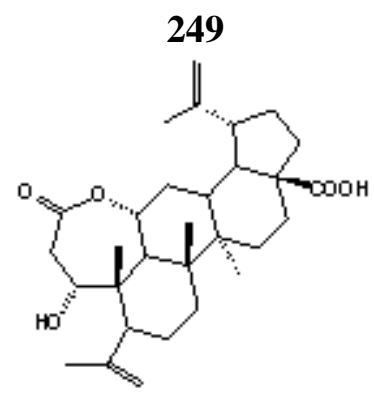

\section{Chiisanoside}

Used in Korean folk medicine, leaves and stem bark of Acanthopanax chiisanensis Nakai (Araliaceae) have been used as an antirheumatic. Chiisanoside, a glycosilated 3,4-secotriterpene of lupane-type with significant anti-inflammatory activity has been isolated from $A$. chiisanensis[138].

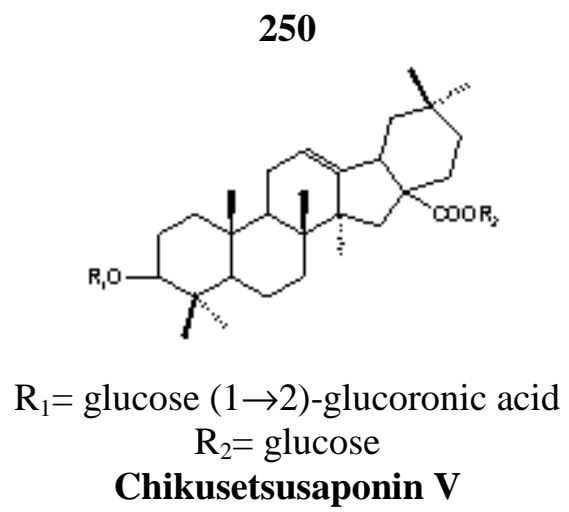

The rhizomes of Panax japonica C.A. Meyer (Araliaceae) have been used for a long time in Japan as a substitute for $P$. ginseng roots of Chinese medicine. A saponin glucoside, chikusetsusaponin $\mathrm{V}$ isolated from the rhizomes of the plant, has shown significant antiinflammatory activity[139]. 


\section{1}

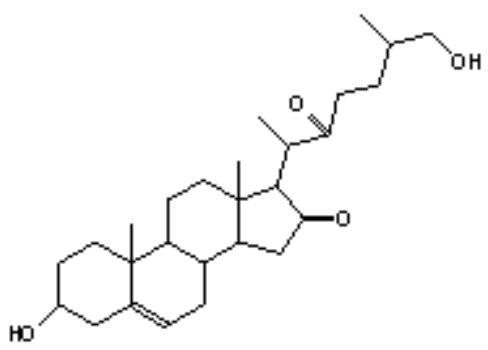

\section{Cryptogenin}

Obtained from Dioscorea mexicana (Dioscoreaceae) roots by extraction with ETOH. $80 \mathrm{mg} / \mathrm{kg}$ i.p. reduced kaolin edema in rats to half, $5 \mathrm{~h}$ after injection[140].

\section{2}

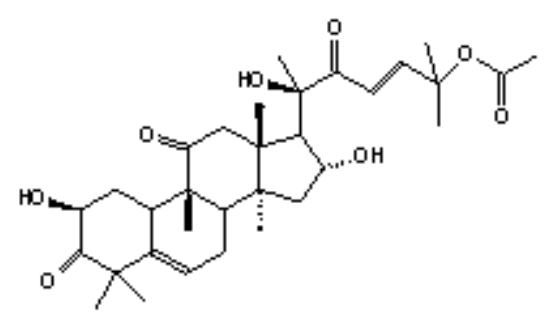

Cucurbitacin

The fruit juice of Ecballium elaterium L.A. Rich (Cucurbitaceae). Used in Turkish folk medicine for the treatment of sinusitis. Has been investigated for its anti-inflammatory activity. The active principle isolated from chloroform extract showed significant anti-inflammatory activity $(69.6 \%$ inhibition of edema)[141].

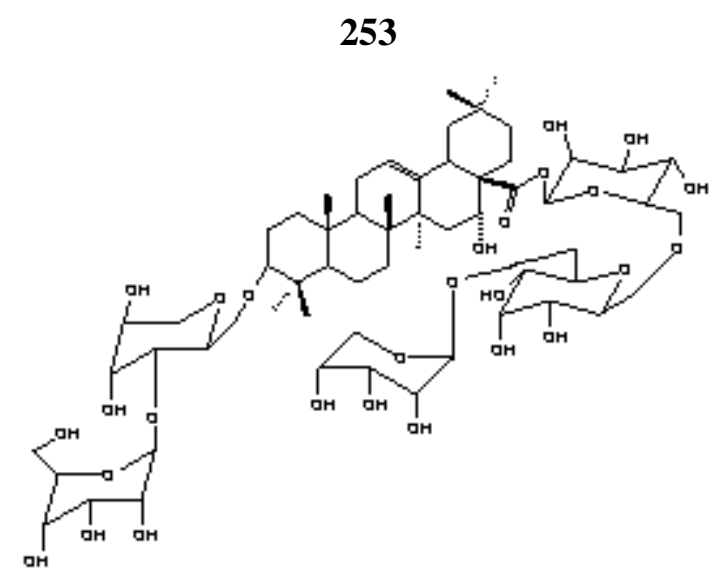

Dulcin

Found in Pitchecellobium dulce (Leguminosae). Showed anti-inflammatory activity[142]. 
<smiles>CC1(C)CC2C3=CCC4C(C)(CCC5C(C)(C)C(=O)CCC54C)C3CCC2(C(=O)O)CC1=O</smiles>

\section{Echinocystic acid}

Possesses activity capable of preventing various chemically induced edemas in rats and abdominal writhings following acetic acid injection in mice[143]. Isolated from Baccharis trimera (Asteraceae) leaves. This South American plant is used in traditional medicine, internally, for the treatment of rheumatism, hepatobiliary disorders, and diabetes.

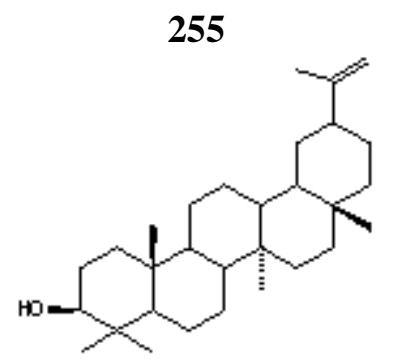

\section{3-Epibetulinic acid}

Showed anti-inflammatory activity[121]. Isolated from Pricramnia pentandra (Simarubaceae) leaves.

256<smiles>C=C(C)[C@H]1CCC2(C(=O)O)CC[C@]3(C)C(CCC4C5(C)CCC(C(=O)O)C(C)(C(=O)O)C5CCC43C)C12</smiles>

Fruticesaponin A
257

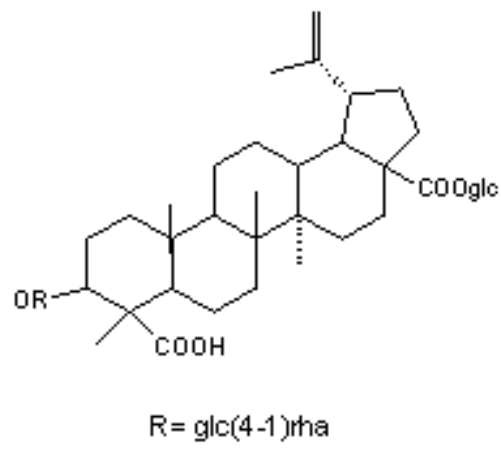

Fruticesaponin B
258<smiles>C=C(C)C1CCC2(O)CC[C@]3(C)C(CCC4C5(C)CC[C@@H](O)C(C)(C(=O)O)C5CCC43C)C12</smiles>

$\mathrm{R}=\mathrm{g} \operatorname{lo}(6-1) g \mathrm{~g}(4) 1) \mathrm{rha}$

Fruticesaponin C

Occur in the dry root of Bupleurum fruticescens (Umbelliferae). Listed officially in the Chinese and Japanese pharmacopoeias and used in Asian traditional medicine to treat certain disorders, are accompanied by inflammation. In vivo anti-inflammatory activity (antidematous activity)[144]. 


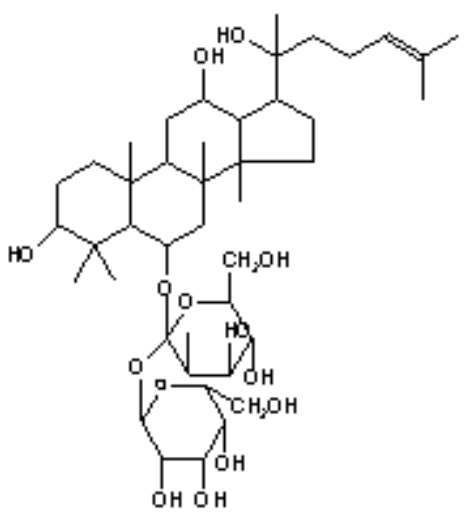

\section{Ginsenoside Ro}

An oleanane-type saponin that has been screened for activity in experimental models of inflammation. Inhibited an increase in vascular permeability in mice induced by acetic acid and reduced an acute paw edema in rats induced by carrageenan[145]. Isolated from roots of red Panax ginseng C.A. Meyer (Araliaceae). Widely prescribed in Chinese medicine in general practice and has been considered to be effective in the management of psychosomatic diseases such as indefinite complaints, stress ulcer, and anxiety neurosis. In addition, ancient literature indicates that ginseng root alleviates some types of inflammatory diseases.

260

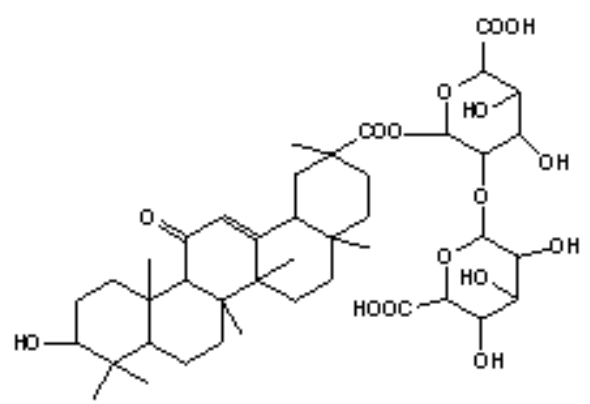

Glycyrrhetinic acid glucoside

261<smiles>CC12C3CCC4(C)C5=CCC6(C)CC(O)C[C@]6(C)C5=CCC4(C)[C@H]1C[C@@H]2O3</smiles>

3ß-p-Hydroxybenzenzoyldehydrotumulosic acid

Occur in the sclerotium of Poria cocos Wolf (Polyporaceae). Used in Chinese herbal prescriptions as a diuretic and a sedative. The $50 \%$ inhibitory doses of the compounds were 0.27 and $1.25 \mathrm{mg}$ per ear on TPA- and AA-induced inflammation[146].

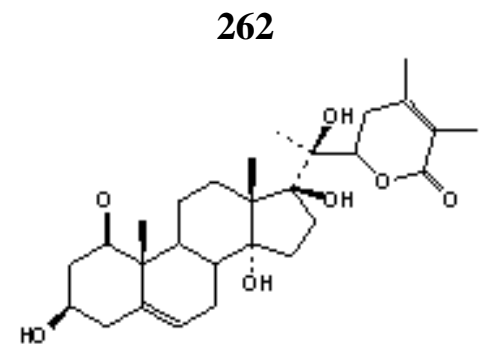

\section{3ß-Hydroxy-2,3-dihydro-withanolide $F$}

Anti-inflammatory activity of $3 \beta$-hydroxy-2,3-dihydro-withanolide $\mathrm{F}$ has been assessed and has marked effects in subacute inflammation. A comparison of the anti-inflammatory properties 
showed it is approximately 5 times more active than phenylbutazone and equally active to that of hydrocortisone on weight basis. The withanolide did not exhibit any effect on CNS[147]. Isolated from Withania coagulans Dunal (Solanaceae) leaves. This plant is used in India for skin afflictions, inflammatory conditions, chronic liver complications, and as a sedative.

\section{3}

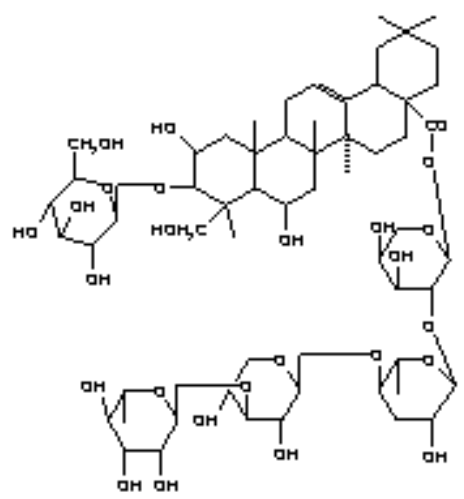

Mi-saponin A

A bisdesmoside of an olean-12 ene-type sapogenol protobassic acid. Obtained from seed kernels of Madhuca longifolia L. Macbride (Sapotaceae). The activity of anti-inflammatory activity was found to be $1 / 4$ of phenylbutazone[148].

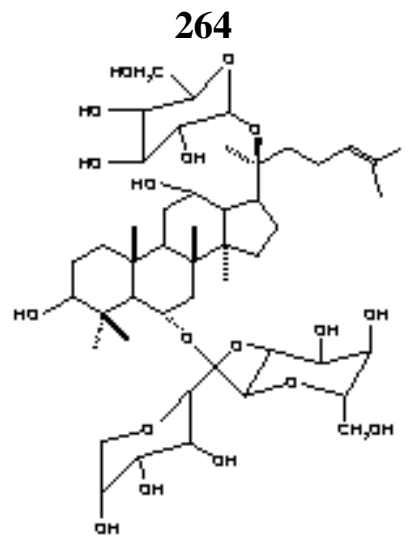

\section{Notoginsenoside R1}

Occurs in Panax notoginseng (Araliaceae). Has anti-inflammatory activity[149].

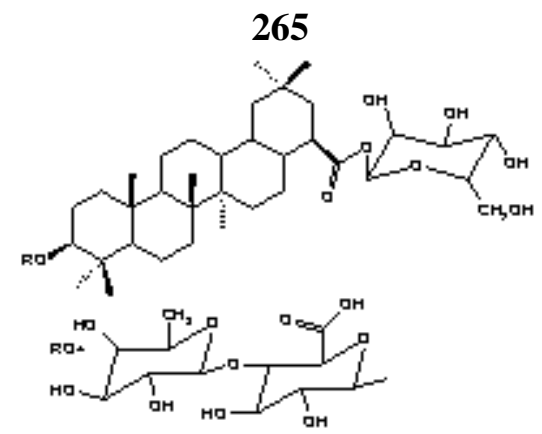

Olaxoside

Found in various Olax spp. (Olaneaceas). Showed strong anti-inflammatory activity[133,134]. 


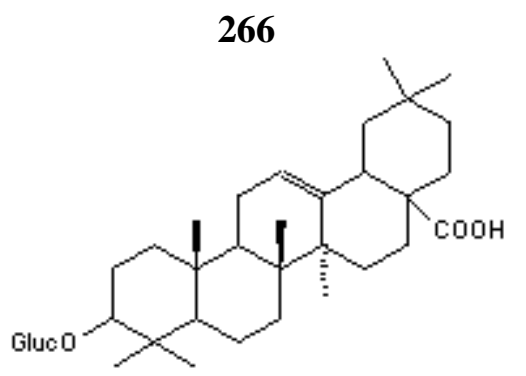

\section{Oleanolic acid 3-glucoside}

Showed significant antiarthritic activity in the exudative and proliferative phases of inflammation in rats[150]. Isolated from Randia dumetorum Lam. (Rubiaceae) seeds.

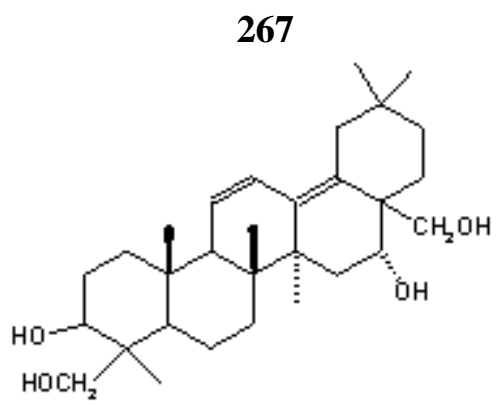

11,13(18)-Oleanadiene 3,16,23,28, tetrol.

A constituent of Bupleurum falacatum. An anti-inflammatory agent[8].

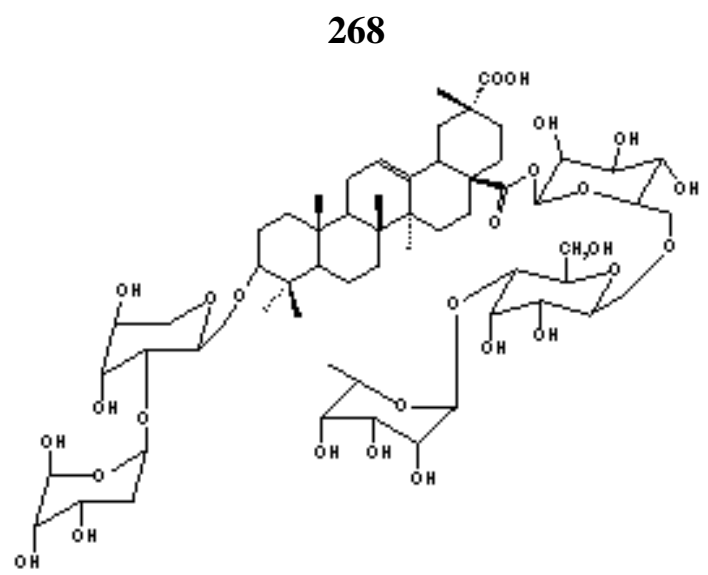

3-O-[ $\alpha$-arabinopyranosyl-(1-2)- $\alpha$-L-arabinopyranosyl]olean-12ene-28,29-dioic acid 28-[O$\alpha$-L-rhamnopyranosyl-(1-4)-D-glucopyranosyl-(1-6) $\beta$-glucopyranoside

Found in the bark of Nothopanax davidii Harms (Araliaceae). Used in traditional Oriental medicine for more than 5000 years. Has anti-inflammatory activity[151]. 


\section{9}

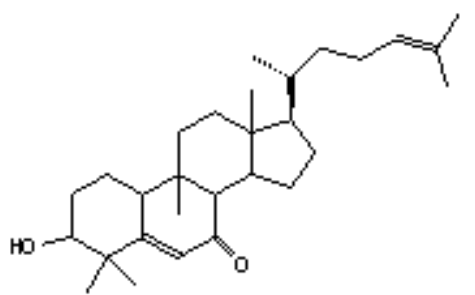

7-0x0-10 $\alpha$-Cucurbita-5,24-dien-3 $\beta$-ol

Isolated from the seeds of Trichosanthes kirilowii Maxim. (Cucurbitaceae). Showed antiinflammatory effect[152].

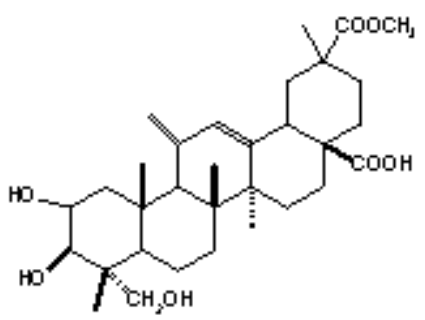

Phytolaccoside B

This saponin is a glucoside of jaligonic acid 30 methyl ether, exhibiting antirheumatic and antiinflammatory actions[153,154]. Isolated from Phytolacca americana L. (Phytolaccaceae) roots.

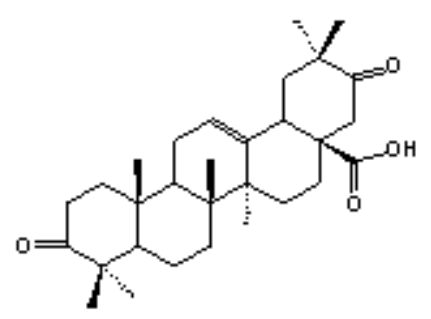

\section{Propapyriogenin $\mathbf{A}_{2}$}

Obtained by acid hydrolysis of the saponin fractions of Tetrapanax papyriferum (Araliaceae) and Bupleurum rotundifolium (Umbelliferae). Showed strong anti-inflammatory activity[133,134].

\section{2}

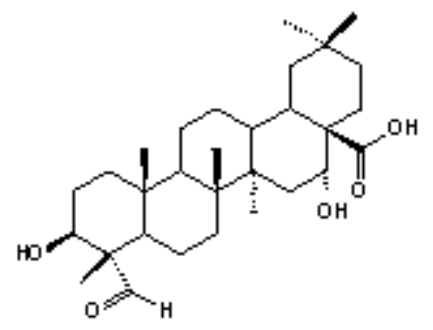

\section{Quillaic acid}

Obtained from the acid hydrolysis of the saponin fraction from the bark of Quillaja saponaria (Rosaceae). The saponin-rich bark of $Q$. saponaria (10\%) is used in shampoo liquids. Shown to have analgesic and anti-inflammatory activity[141]. 


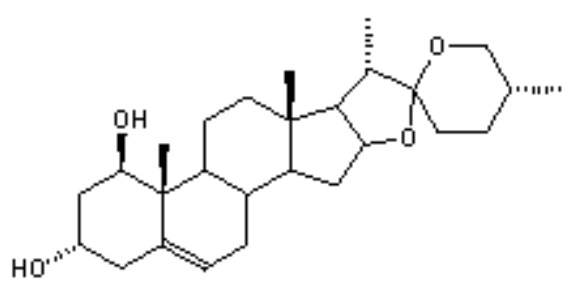

\section{Ruscogenin}

Occurs in Ruscus aculeatus. Used in the local treatment of hemorrhoids. Showed antiinflammatory effect[8].

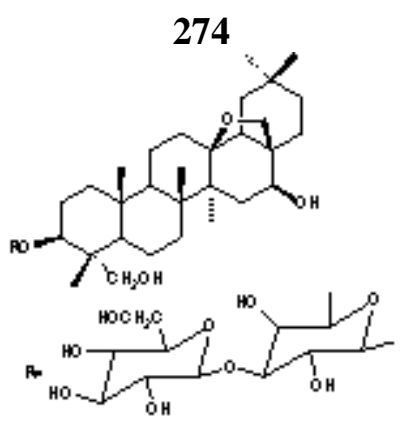

Saikosaponin A

The roots of Bupleurum falcatum L.B. chinense (Umbelliferae) are used in Chinese medicine for the treatment of inflammation of the diaphragm and enlargement of the liver caused by hepatitis. A number of saikosaponins have been isolated and the aglycone part was found to have oleananetype structure with a characteristic unsaturation at C-11 and 13/,28-oxide system. The administration of saikosaponins has no side effect such as shrinking of the adrenal gland that often occurs with the administration of prednisolone[106].

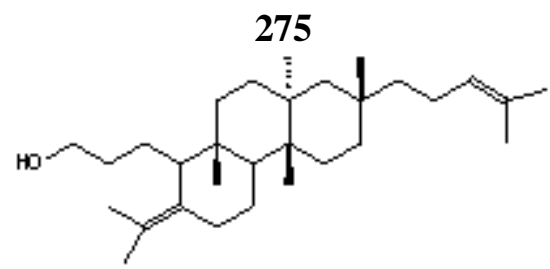

\section{Sasanquol}

Found in the seed of Camellia sasanqua Thumb (Theaceae). The 50\% inhibitory dose of this compound against TPA-induced ear inflammation ( $1 \mu \mathrm{g}$ per ear) in mice was 0.4 per ear[155].

276

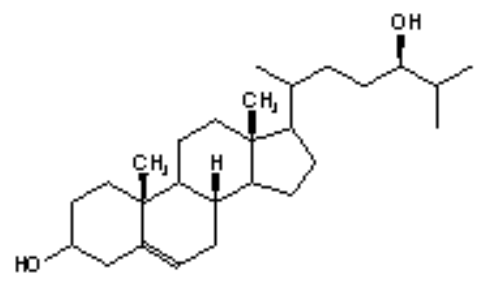

\section{$\beta$-Sitosterol}

The anti-inflammatory and antipyretic activities of $\beta$-sitosterol isolated from Cyperus rotundus (Ciperaceae) and Bryophyllum pinnatum (Crassulaceae) leaves have been studied, employing 
carrageenan-induced edema, cotton pellet implantation, and Brewer's yeast-induced pyrexia in rats. $\beta$-Sitosterol was found to possess potent anti-inflammatory activity against both tests, similar to hydrocortisone and oxyphenbutazone when administered i.p.[156,157].

277

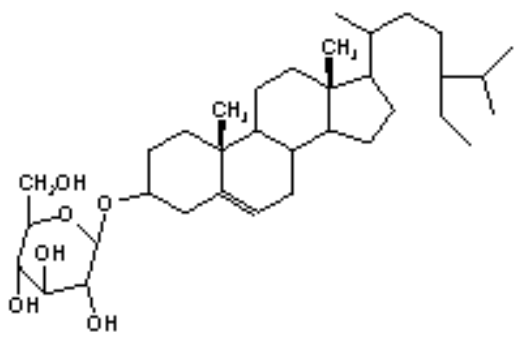

\section{$\beta$-Sitosterol- $\beta$-D-glucopyranoside}

The isolated glucoside from Sechium edule (Cucurbitaceae) leaves was tested against phenylbutazone and the vehicle control using dextran-induced rat paw edema method[158].

279

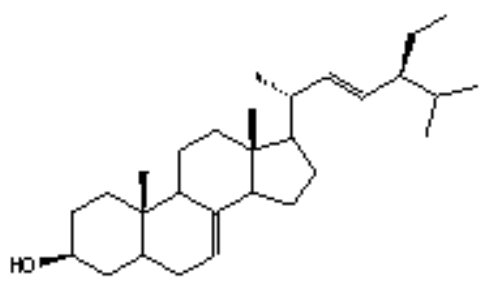

$\alpha$-Spinasterol

Showed significant activity against acute inflammation induced by carrageenan in rats and was more potent than phenylbutazone but less potent than betamethasone[159]. Isolated from Symplocos spicata Roxb. (Symplocaceae) roots.

\section{0}

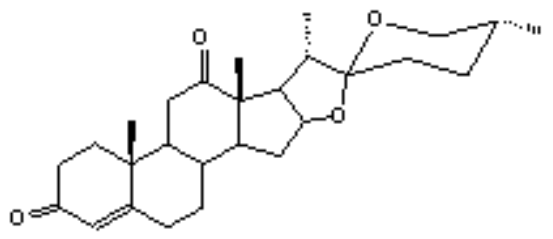

25R-Spirostan-4-ene-3,12-dione

Found in Polygonum chinensis L. Polygonaceae. Has anti-inflammatory and antiallergic activities[160,161]. Treatment of dysentery. 
281<smiles>C=C1C=C2C3CC(C)(C(C)=O)CCC3(C(=O)O)CC[C@]2(C)[C@@H]2CCC3C(C)(CO)C(O)C(O)CC3(C)C12</smiles>

Terminolic acid
282

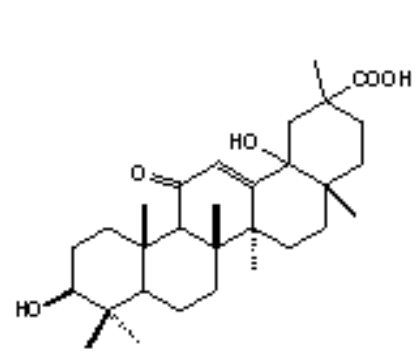

Glycyrrhezinic acid<smiles>CC1(C(=O)O)CCC2(CO)CC[C@]3(C)C(=CC(=O)C4CCC5(C)CC[C@H](O)C(C)(CO)C5CCC43C)C2C1</smiles>

Lonchoterpene

Terminolic acid, glycyrrhetinic acid, and lonchoterpene showed anti-inflammatory activity[162]. Isolated from Terminalia ivorensis (Combretaceae) bark. The glycyrrhezinic acid potentiates the antiarthritic action of hydrocortisone in rats and showed anti-inflammatory activity in 1/8 potency of cortisol by the cotton pellet method[133]. Isolated from Glycyrrhiza glabra Linn (Leguminosae) roots.

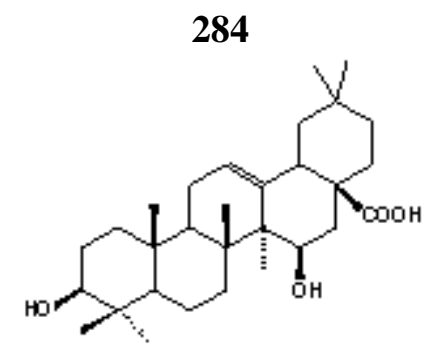

Triptotriterpenic acid

Showed anti-inflammatory activity[121]. Isolated from Tripterygium wilfordil leaves.

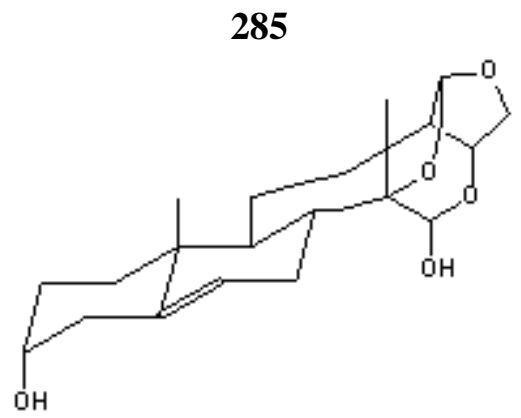

Velutinol A

Has antibradykinin, anti-inflammatory activity[163]. The structure of velutinol A comprises a novel pregnane skeleton, and steroids of this class are commonly encountered in Apocinaceae[164]. Extracted from Mandevilla velutina (Aponcinaceae) rhizomes. 
286

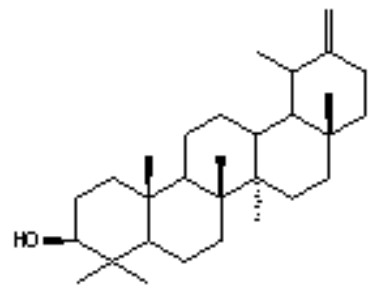

Taraxasterol

289

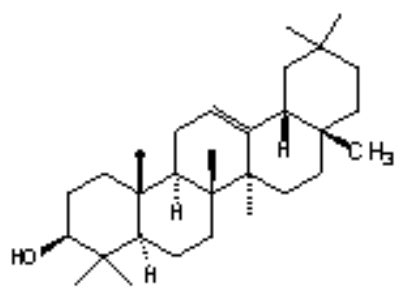

$\beta$-Amyrin
287<smiles>C=C(CCC=C(C)C)C1CC[C@]2(C)C1CCC1C3(C)CCC(O)C(C)(C)C3CCC12C</smiles>

Dammaradienol

290

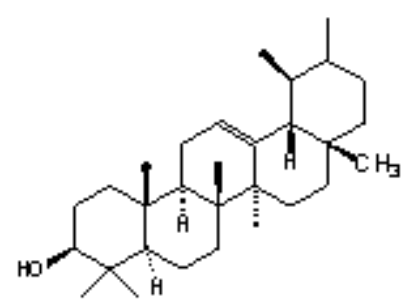

$\alpha$-Amyrin
288<smiles>CC(C)CCCC1CC[C@]2(C)C1CCC1C2CCC2C(C)(C)C(O)CCC12C</smiles>

Cycloartenol

291<smiles>CC(C)=C1CCC(C)CC2C3=CCC4C(C)(C)C(O)CCC4(C)C3CCC12</smiles>

Tirucalla-7,24-dienol

\section{2}<smiles>C=C(C)C1CCC2(C)CC[C@]3(C)C(CCC4C3CCC3C4(C)CC[C@H](O)C3(C)C)C2C1</smiles>

\section{Lupeol}

Six species of Compositae plants - Calendula officinalis, Carthamus tintorius, Cosmos bipinnatus, Chrysanthemus morifolium, Helianthus annuus, and Matricaria matricarioides were investigated for their triterpene alcohol constituents. This led to the isolation and identification of 11 triterpene alcohols as follows: Helaniol, Taraxerol, Dammaradienol, $\beta$ amyrin, Cycloartenol, Tirucalla-7,24-dienol, $\alpha$-amyrin, Lupeol, 24-methylenecycloartanol, $\psi$ taraxasterol, and Taraxasterol. Triterpene alcohols isolated from the Compositae flowers in this study were examined for their inhibitory effects on TPA-induced inflammation in mice. The inhibitory activities were compared with indomethacin and hydrocortisone. All of the triterpene alcohols markedly inhibited the TPA-induced inflammation[165]. Also inhibited eukaryote signal-regulated protein kinases[166]. 
293

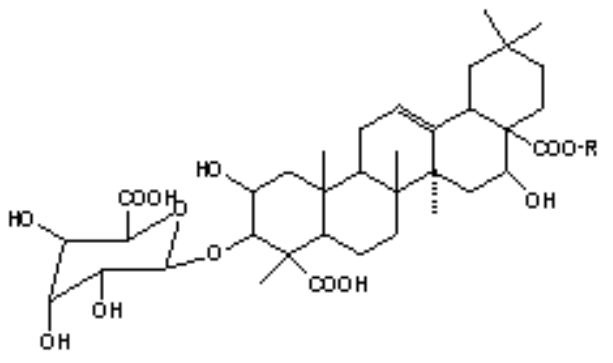

Zanhasaponin A
294

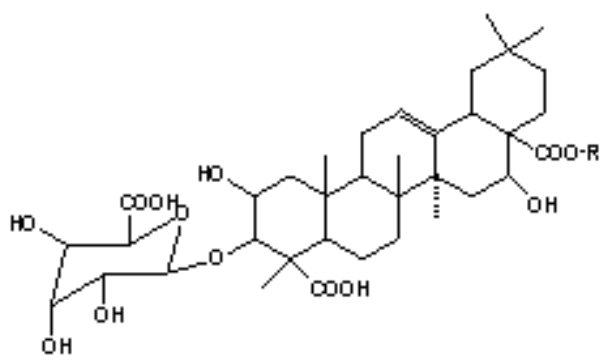

Zanhasaponin B

Found in Zanha africana root bark (Sapindaceae). Used in traditional medicine in Southern Africa for the treatment of dysentery. Have anti-inflammatory activity[161].

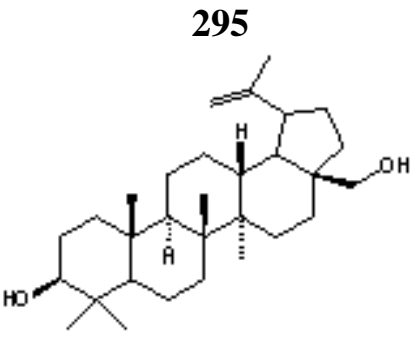

Betulin
296

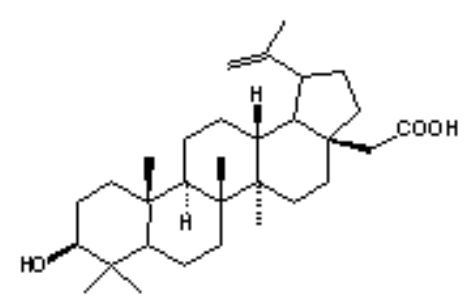

Betulinic acid
297<smiles>CC1CCC2(C(=O)O)CCC3C2CCC2(C1C)C3CCC1CC(O)CCC12C</smiles>

Ursolic acid

Three anti-inflammatory triterpenes — betulin, betulinic acid, and ursolic acid - were isolated from Diospyros leucomelas L. (Ebenaceae) leaves. They showed anti-inflammatory activity in the carrageenan and serotonin paw edema tests and TPA and EPP ear edema tests. The blockade of their effects by progesterone, actinomycin $\mathrm{D}$, and cycloheximide has served to determine the mechanism of action in relationship with that of glucocorticoides[167].

\section{XANTHONES}

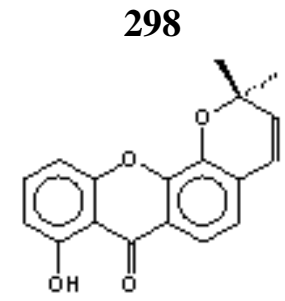

\section{Dehydrocycloguandin}

The anti-inflammatory activity has been demonstrated on the exudative and proliferative phases of cotton pellet granuloma, formaldehyde-induced arthritis, and carrageenan edema[168]. Isolated from Calophyllum brasiliense and C. inophyllum (Guttiferae) leaves.

299<smiles>CC1(C)Cc2cc3oc4c(O)cccc4c(=O)c3c(O)c2C1</smiles>

6-Deoxyjacareubin 
Significantly inhibited carrageenan- and yeast-induced edema and cotton pellet inflammation[168]. Isolated from leaves of Calophyllum zeylanicum and Kielmeyera speciosa (Guttiferae).

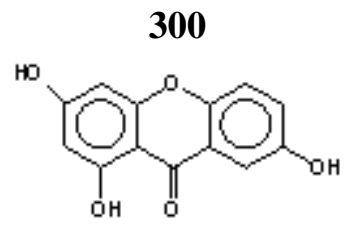

Euxanthone

A xanthone. Exhibited anti-inflammatory activity[169]. Isolated from seeds of Mammea americana (Guttiferae).

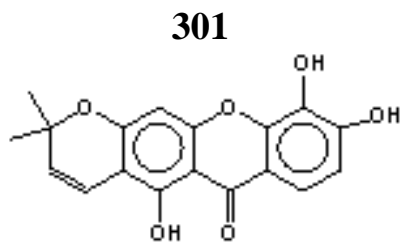

Jacareubin

Found in the wood of Calophyllum brasiliense, Kielmeyera ferruginea, and Pentadesma butyracea (all Gutiferae). Has anti-inflammatory activity[169].

302

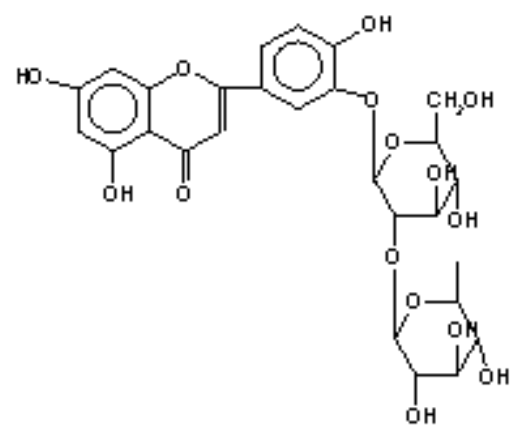

Luteolin-4'-O-neohesperidoside

Has significant anti-inflammatory action. More potent than ibuprofen. Isolated from Caralluma attenuata Wight (Asclepiadaceae)[55].

303<smiles>O=c1c2cc(O)c(O)cc2oc2cc(O)c(O)c(O)c12</smiles>

Mangiferin
304

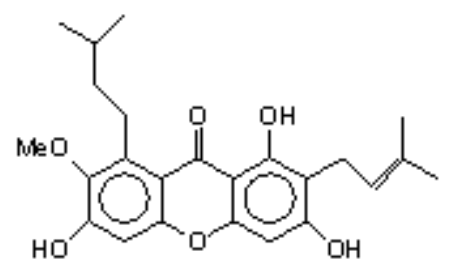

Mangostin

Xanthone mangiferin and phenylated xanthone mangostin have been found to exert pronounced anti-inflammatory activity when tested against different models of experimental inflammation[170]. Isolated from leaves of Swertia chirata Buch-Ham (Gentianaceae). This plant is used in the Indian system of medicine as an antimalarial, and liver tonic. Mangiferin exhibits 
significant anti-inflammatory properties at a dose of $50 \mathrm{mg} / \mathrm{kg}$. They do not have analgesic or antipyretic effects but show antiulcer activity[169]. Isolated from leaves of Canscora decussata Schult (Gentianaceae) and Cratoxylua prunifiorus Kurz (Guttiferae).

305<smiles>COc1cc(O)c2c(=O)c3cccc(O)c3oc2c1</smiles>

Mesuaxanthone A
306<smiles>O=c1c2cccc(O)c2oc2c(O)c(O)ccc12</smiles>

Mesuaxanthone B

The leaves of Mesua ferrea (Guttiferae) have been used to treat inflammatory diseases. The activity is due at mesuaxanthone $\mathrm{A}$ and $\mathrm{B}$, that inhibited the increase in edema of the rat paw induced by carrageenan[168].

\section{REFERENCES}

1. Lombardino, J.G. (1985) Nosteroidal Antiinflammatory Drugs. Wiley Interscience, New York.

2. Tang, X.C., Lin, Z.G., Cai, W., Chen, N., and Shen, L. (1984) Antiinflammatory effect of 3-acetylaconitine. Acta Pharmacol. Sin. 5, 85-89.

3. Manske, R.H.F. and Brossi, A., Eds. (1985) The Alkaloids. Vol. 24. Wiley, New York. pp 253-286.

4. Cordell, G.A. (1981) Introduction to Alkaloids: Biogenetic Approach. Wiley, New York.

5. Panthong, A., Kanjanapothi, D., Thitiponpunt, Y., Taesotikul, T., and Arbain, D. (1998) Antiinflammatory activity of the alkaloid bukittinggine from Sapium baccatum. Planta Med. 64, 530-535.

6. Martindale, A. (1989) The Extra Pharmacopoeia. $28^{\text {th }} / 29^{\text {th }}$ ed. Pharmaceutical Press, London. pp. $234-237$.

7. Manske, R.H.F. and Brossi, A., Eds. (1990) The Alkaloids. Vol. 36. Wiley, New York. pp 1-68.

8. Djerassi, C., Connolly, J.D., and Faulkner, D.J. (1994) Dictionary of Natural Products. Chapman and Hall, London.

9. Chen, I., Chen, J., Tsai, I., Chang, Y., and Teng, C. (1995) New p-quinonoid aporphine alkaloids and antiplatelet aggregation constituents of Hernandia sonora. Planta Med. 61, 537-539.

10. Simanek, V. (1985) In The Alkaloids. Vol. 26. Brossi, A., Ed. Academic Press, London. pp 185-240.

11. Shamma, M. and Moniot, J.L. (1978) Isoquinoleine Alkaloid Research 1972-1977. Plenum Press, New York.

12. Benn, M.H. and Jacyno, J.M. (1983) The toxicology and pharmacology of diterpenoids alkaloids. In Alkaloids: Chemical and Biological Perspectives. Pelletier, S.W., Ed. Wiley, New York. pp 153-210.

13. Phillipson, J.D., Roberts, M.F., and Zenk, M.H. (1985) The chemistry of alkaloids by chromatographic analysis. In The Alkaloids. Vol. 32. Brossi, A., Ed. Academic Press, New York. pp. 1-78.

14. Piattelli, M. (1976) In Betalains in Chemistry and Biochemistry of Plant Pigments. $2^{\text {nd }}$ ed. Goodwin, T.W., Ed. Acedemic Press, London. pp. 560-596.

15. Arens, H., Fisher, H., Leyck, S., Romer, A., and Ulbrich, B. (1985) Antiinflammatory compounds from Plagiorhegma dubium cell culture. Planta Med. 52-56.

16. Gerashchenko, V.F., Bondarenko, G.L., and Semenchenko, V.F. (1970) Anti-inflammatory activity of jervine. Aktual. Vop. Farm. 1968; Chem. Abstract. 76: 108077p, 1972.

17. Shamma, M. (1972) The Isoquinoline Alkaloids. Academic Press, New York.

18. Manske, R.H.F. and Brossi, A., Eds. (1988) The Alkaloids. Vol. 34. Academic Press, New York. pp 331398.

19. Gao, Y.G., Song, Y.M., Yang, Y.Y., Liu, W.F., and Tang, J.X. (1979) Pharmacology of tanshinone. Acta Pharmacol. Sin. 14, 75-82.

20. Roddick, J.G. (1986) Steroidal alkaloids of the Solanaceae. In Solanaceae Biology and Systematics. D’Arcy, W.G., Ed. Columbia University Press, New York. pp. 201-222. .

21. Lue, F.H., Chang, T.M., and Fong, T.C. (1957) The antiphlogistic and antianaphylactic shock actions of tetrandrine and demethyltetrandrine. Acta Pharmacol. Sin. 5, 113-122.

22. Wu, Y., Wu, T., Niwa, T., Lu, S., Hirata, Y., McPhail, D., McPhail, A., and Lee, K. (1988) Structure and stereochemistry of Thialicsiline, a new antiinflammatory $\mathrm{C} 20$-diterpenoid alkaloid from Thalictrum sessile. Heterocycles 27, 1813-1816.

23. Johji, H., Sawada, T., and Fujimura, H. (1975) Pharmacological actions of alkaloids of menispermaceous plants. Pharmacological actions of trilobine and isotrilobine. Syoyakugaku Zasshi 28, 96-101. 
24. Handa, S.S., Chawla, A.S., and Sharma, A.K. (1992) Plant with antiinflammatory activity. Fitoterapia LXIII, 3-31.

25. Hikino, H., Konno, C., Tarata, H., and Tamada, M. (1980) Antiinflammatory principle of Ephedra herbs. Chem. Pharm. Bull. 28, 2900-2904.

26. Konno, C., Mitsuru, T., Tamada, M., and Hikino, H. (1980) Ephedroxane, anti-inflammatory principle of Ephedra herbs. Phytochemistry 18, 697-698.

27. Omaye, S.T., Koserky, D.S., and Malone, M.H. (1972) Anti-inflammatory activity of alkaloids from Heimia salcifolia. Proc. West. Pharmacol. Soc. 15, 205.

28. Vavreckova, C., Gawlik, I., and Muller, K. (1996) Benzophenanthridine alkaloids of Chelidonium majus. I. Inhibition of 5- and 12-lipoxygenase by a non-redox mechanism. Planta Med. 62, 397-401.

29. Lenfeld, J., Kroutil, M., Marsalek, E., Slavik, J., Preininger, V., and Simanek, V. (1981) Antiinflammatory activity of quaternary benzophenanthridine alkaloids from Chelidonium majus. Planta Med. 43, 161-165.

30. Singh, S., Garg, H., and Khanna, N.M. (1976) Dybsobinin, a new tetranortriterpene from Dysoxylum binectariferum. Phytochemistry 15, 2001-2002.

31. Naik, R.G., Kattice, L.S., Bhat, S.V., Alreja, B., Souza, N.J., and Rupp, R.H. (1988) An anti-inflammatory cum immunomodulatory piperidinylbenzopyranone from Dysoxylum binectariferum: isolation, structure and total synthesis. Tetrahedron 44, 2081-2086.

32. Saxena, R.C., Nath, R., Palit, G., Nigam, S.K., and Bhargava, K.P. (1982) Effect of calophyllolide, a new nonsteroidal anti-inflammatory agent, on capillary permeability. Planta Med. 44, 246-248.

33. Chaturvedi, A.K., Parmar, S.S., Bhatnagar, S.C., Mistra, G., and Nigam, S.K. (1974) Anticonvulsant and anti-inflammatory activity of natural plant coumarins and triterpenoids. Res. Commun. Chem. Pathol. Pharmacol. 9(1), 11-22; Chem. Abstr. 82: 38600b, 1975.

34. Liu, G.Q., Jiang, Y., Wang, Q.J., and Yang, E.X. (1977) Pharmacological studies on daphnetin. Zhongcaoyao Tongxum 3, 117-120.

35. Pitre, S. and Srivastava, S.R. (1987) Pharmacological, microbiological and phytochemical studies on roots of Aegle marmelos. Fitoterapia LVIII, 194-197.

36. Kosuge, T., Yoroto, M., Sugiyama, K., Yamamoto, T., Mure, T., and Yamazawa, H. (1985) Studies on bioactive substances in crude drugs used for arthritic diseases in traditional Chinese medicine. II. Isolation and identification of an anti-inflammatory and analgesic principles from the root of Angelica pubescens Maxim. Chem. Pharm. Bull. 33, 5351-5354.

37. Zhu, H.L. and Huang, J.C. (1984) Anti-inflammatory action of scopoletin. Chin. Trad. Herbal Drugs 15, 462-465.

38. Furuta, T., Fukuyama, Y., and Asakawa, Y. (1986) Polygonolide, an isocoumarin from Polygonum hydropiper possessing anti-inflammatory activity. Phytochemistry 25, 517-520.

39. Silvan, A., Abad, M., Bermejo, P., Sollhuber, M., and Villar, A. (1996) Antiinflammatory activity of coumarins from Santolina oblongifolia. J. Nat. Prod. 59, 1183-1185.

40. Wang, H., Nair, M., Strasburg, G., Chang, Y., Booren, A., Gray, J.I., and Witt, D. (1999) Antioxidant and antiinflammatory activities of anthocyanins and their aglycon, cyanidin, from tart cherries. J. Nat. Prod. 62, 294-296.

41. Harbone, J.B. (1988) The Flavonoids: Advances in Research since 1980. Chapman and Hall, London.

42. Cody, V., Middleton, E., and Harbone, J.B. (1986) Plant Flavonoids in Biology and Medicine. Alan R. Liss, New York.

43. Sertie, J.A., Basile, C.A., Panizza, S., Matida, K.A., and Zelnik, R. (1990) Anti-inflammatory activity and sub-acute toxicity of Artemetin. Planta Med. 56, 36-40.

44. Otsuka, H., Shoji, F., Takeya, K., Mitzuta, E., and Masayuki, T. (1982) Studies on anti-inflammatory agents. VI. Anti-inflammatory constituents of Cinnamomum sieboldii Meissn. Yakugaku Zasshi 102(2), 162-172; Chem. Abstract. 96: 223079r, 1982.

45. Kubo, M., Matsuda, H., Tanaka, M., Kimura, Y., Okuda, H., Higashino, M., Tani, T., Namba, K. (1984) Studies on Scutellarie radix. VII. Anti-arthritic and anti-inflammatory actions of methanolic extract and flavonoids components from Scutellarie radix. Chem. Pharm. Bull. 32, 2724-2729.

46. Van Sumere, C.F. (1989) Phenols and phenolic acids. In Methods in Plant Biochemistry. Vol. 1. Plant Phenolics. Harbone, J.B., Ed. Academic Press, London. pp. 29-74.

47. Harbone, J.B. and Mabry, T.J. (1982) The Flavonoids: Advances in Research. Chapman and Hall, London.

48. Harbone, J.B. (1989) Phytochemical Methods. $2^{\text {nd }}$ ed. Chapman and Hall, London.

49. Hikino, H. and Riso, Y. (1988) Economic and Medicinal Plant Research. Vol. 2. Academic Press, New York. pp. 39-43.

50. Min, K., Hwang, B.Y., Lim, H., Kang, B., Oh, G., Lee, J., Kang, S., Lee, K., and Kim, Y. (1999) (-)Epiafzelechin: cyclooxygenase-1 inhibitor and antiinflammatory agent from aerial parts of Celastrus orbiculatus. Planta Med. 65, 460-462.

51. Noreen, Y., El-Seedi, H., Perera, P., and Bohlin, L. (1988) Two new isoflavones from Ceiba pentandra and their effect on cyclooxygenase-catalyzed prostaglandin biosynthesis. J. Nat. Prod. 61, 8-12.

52. Villar, A., Gasco, A., Alcaraz, M.J., Mañez, S., and Cortes, D. (1984) Hypolaetin-8-O-glucoside, an antiinflammatory flavonoid from Sideritis mugronensis. Planta Med. 70. 
53. Alcaraz, M.J. and Hoult, J.R.S. (1985) Actions of flavonoids and the novel antiinflammatory flavone, hypolaetin-8-glucoside, on prostaglandin biosynthesis and inactivation. Biochem. Pharmacol. 34, 2477-2482.

54. Saini, K.S. and Ghosal, S. (1984) Naturally occurring flavans unsubstituted in the heterocyclic ring. Phytochemistry 23, 2415-2421.

55. Ramesh, M., Nageshwar, Y., Appa Rao, A.V., Prabhakar, M.C., Seshagiri, C., Muralidhar, N., and Madahava, B. (1998) Antinociceptive and anti-inflammatory activity of a flavonoid isolated from Caralluma attenuata. J. Ethnopharmacol. 62, 63-66.

56. Cabor, M. (1979) In Handbook of Experimental Pharmacology Anti-Inflammatory Drugs. Vane, J.R. and Ferreira, S.H., Eds. Springer, New York. p. 698.

57. Arens, H., Ulbrich, B., Fischer, H., Parnham, M.J., and Romer, A. (1986) Novel antiinflammatory flavonoids from Podopyllum versipelle cell culture. Planta Med. 52, 468-473.

58. Grayner, R.J. (1989) Flavanoids. In Methods in Plant Biochemistry. Vol. 1. Academic Press, London. pp. 285-287.

59. Sethuraman, V. and Sulochana, N. (1988) The antiinflammatory activity of Physalis minima. Fitoterapia LIX, 335-336.

60. Recio, M.C., Giner, R.M., Mañez, S., Talens, A., Cubells, L., Gucho, J., Julien, H.R., Hostettmann, K., and Rios, J.L. (1993) Anti-inflammatory activity of flavonol glycosides from Erythrospermum monticolum depending on single or repeated local TPA administration. Planta Med. 61, 502-504.

61. Agrawal, P.K., Agrawal, S.K., Rastogi, R.P., and Osterdahal, B.G. (1981) Dihydroflavanonols from Cedrus deodara a ${ }^{13}$ CNMR study. Planta Med. 43, 82-85.

62. Prabhakar, M.C., Bano, H., Kurnar, I., Shami, M.A., and Khan, M.S. (1981) Pharmacological investigation on vitexin. Planta Med. 43, 396-403.

63. Harbone, J.B. and Mabry, T.J. (1975) The Flavonoids. Chapman and Hall, London.

64. Gabor, M. (1979) In Handbook of Experimental Pharmacology Anti-Inflammatory Drugs. Vane J.R. and Ferreira S.H., Eds. Springer, New York.

65. Williams, C., Harbone, J., Geiger, H., and Hoult, R. (1999) The flavonoids of Tanacetum parthenium and T. vulgare and their anti-inflammatory properties. Phytochemistry 51, 417-423.

66. Middleton, E. and Kandaswami, C. (1994) The Flavonoids: Advances in Research since 1986. Harborne, J.B., Ed. Chapman and Hall, London. pp. 622-633.

67. Noreen, Y., Serrano, G., Perera, P., and Bohlin, L. (1998) Flavan-3-ols isolated from some medicinal plants inhibiting COX-1 and COX-2 catalysed prostaglandin biosynthesis. Planta Med. 64, 520-524.

68. Chan, S., Chan, Y., Wang, J., Chen, S., and Kuo, S. (1998) Three new flavonoids and antiallergic, antiinflammatory constituents from the heartwood of Dalbergia odorifera. Planta Med. 64, 153-158.

69. Chung, C., Park, J., and Bae, K. (1995) Pharmacological effect of methanolic extract from the root of Scutellaria baicalensis and its flavonoids on human gingival fibroblast. Planta Med. 61, 150-153.

70. Palanichamy, S. and Nagarajan, S. (1990) Anti-inflammatory activity of Cassia alata leaf extract and kaempferol-3-O-sophoroside. Fitoterapia LXI, 44-47.

71. Heywood, V.H., Harbone, J.B., and Turner, B.L. (1977) The Biology and Chemistry of the Compositae. Vol. 1. Academic Press, London.

72. Mix, D.B., Guinaudeau, H., and Shamma, M. (1982) The aristolochic acids and aristolactams. J. Nat. Prod. 45, 657-666.

73. Boulter, D. and Parthier, B. (1982) Structure, biochemistry and physiology of proteins. In Encylopedia of Plant Physiology. New Series 14a. Springer-Verlag, Berlin.

74. Hutter. J.A., Salman, M., Stavinoha, W., Satsangi, N., Williams, R., Streeper, R., and Weintraub, S. (1996) Antiinflammatory C-glucosyl chromone from Aloe barbadensis. J. Nat. Prod. 59, 541-543.

75. Breu, K.R., Davis, B., and Bauer, R. (1994) Anti-inflammatory active polyacetylenes from Bidens campylotheca. Planta Med. 60, 58-62.

76. Nicoletti, M., Pieretti, S., Capasso, A., and Galeffi, C. (1996) Analgesic effect induced by Hypoxoside, a norlignan glucoside from Hypoxis spp. Phytother. Res. 10, 398-401.

77. Dean, F.M. (1963) Naturally Occurring Oxygen Ring Compounds. Butterworths, London.

78. Kimura, M., Suzuki, J., Yamada, T., Yoshizaki, M., Kikuchi, T., Kadota, S., and Matsuda, S. (1985) Antiinflammatory effect of neolignans newly isolated from the crude "shin-i" (Flos magnoliae). Planta Med. 291-293.

79. Kadota, A., Osaka, Y., and Kenkyusho, K.K. (1987) Isolation of analgesic, anti-inflammatory monoglycerides from aconitum chinense. inflamatories. Jpn. Kokai Tokkyo Koho JP 61,191,619 [86,191,619]. Chem. Abstract. 106: 72911c, 1987.

80. Okpanyl, S.N. and Ezeukwu, G.C. (1981) Anti-inflammatory and antipyretic activities of Azadirachta indica. Planta Med. 41, 34-39.

81. Pillai, N.R. and Santhakumari, G. (1981) Anti-arthritic and anti-inflammatory actions of nimbidin. Planta Med. 43, 59-63.

82. Ambasia, S.P. (1986) The Useful Plants of India. Publication and Information Directorate, CSIR, New Delhi. pp. 437-443. 
83. Dey, P.M., Ed. (1990) Methods in Plant Biochemistry. Vol. 2. Carbohydrates. Academic Press, London.

84. Preiss, J., Ed. (1980) The Biochemistry of Plants. Vol. 3. Carbohydrates, Structure and Function. Academic Press, San Diego.

85. Whistler, R.L., Bushway, A.A., and Singh, P.P. (1976) Noncytotoxic antitumor polysaccharides. $A d v$. Carbohydr. Chem. Biochem. 32, 235-275.

86. Leung, A.Y. (1989) Encyclopedia of Common Natural Products used in Food, Drugs and Cosmetics. John Wiley \& Sons, New York. pp. 47-53.

87. Chen, Y.F., Tsai, H.Y., and Wu, T.S. (1995) Anti-inflammatory and analgesic activities from roots of Angelica pubescens. Planta Med. 61, 2-8.

88. Kosuge, T., Yoroto, M., Sugiyama, K., Yamamoto, T., Mure, T., and Yamazawa, H. (1985) Studies on bioactive substances in crude drugs used for arthritic diseases in traditional chinese medicine. III. Isolation and identification of an anti-inflammatory and analgesic principles from the whole herb of Pyrola rotundifolia L. Chem. Pharm. Bull. 33, 5355-5357.

89. Ibrahim, R. and Barron, D. (1989) Phenylpropanoids. In Methods in Plant Biochemistry. Vol. 1. Plant Phenolics. Harbone, J.B., Ed. Academic Press, London. pp. 75-112.

90. Hall, I.H., Lee, K.H., and Sykes, C. (1987) Anti-inflammatory agents. IV. Structure activity relationships of sesquiterpene lactone esters derived from helenalin. Planta Med. 53(2), 153-156.

91. Picman, A.K. (1986) Biological activities of sesquiterpene lactones. Biochem. Syst. Ecol. 14, 255-257.

92. Herout, V. (1971) Biochemistry of sesquiterpenoids. In Aspects of Terpenoid Chemistry and Biochemistry. Goodwin, T.W., Ed. Academic Press, London. pp. 53-94.

93. Jury, S.L., Reynolds, T., Cutler, D.F., and Evans, F.J. (1987) The Euphorbiales: Chemistry, Taxonomy and Economic Botany. Academic Press, London.

94. Rudakov, G.A. (1976) Chemistry and Technology of Camphor. $2^{\text {nd }}$ ed. Academic Press, London, 254 p..

95. Dequan, L.Y. and Fengzhi, X. (1987) Chemical constituents of Chrysanthemus indicum L. Yaoxue Xuebao 22, 837-840.

96. Singh, M., Pal, M., and Sharma, R.P. (1999) Biological activity of the labdane diterpenes. Planta Med. 65, 2-8.

97. Matsumoto, T., CholCyong, J., and Yamada, H. (1992) Stimulatory effects of ingenols from Euphorbia kansui on the expression of macrophage Fc receptor. Planta Med. 58, 255-258.

98. Abad, M.J., Bermejo, P., Valverde, S., and Villar, A. (1994) Anti-inflammatory activity of hydroxyachillin a sesquiterpene lactone from Tanacetum microphyllum. Planta Med. 60, 228-231.

99. Milonava, R., Han, K., and Moore, M. (1995) Oxidation and glucose conjugation of synthetic abietane diterpenes by Cunninghamella SP II. Novel routes to the family of diterpenes from Tripterygium wilforddi. J. Nat. Prod. 58, 68-73.

100. Giordano, O.S., Guerreiro, E., Pestchanker, M.J., Guzman, J., Pastor, D., and Guardia, T. (1990) The gastric cytoprotective effect of several sesquiterpene lactones. J. Nat. Prod. 53, 803-809.

101. Matsuda, H., Yoshikawa, M., Linuma, M., and Kubo, M. (1998) Antinociceptive and antiinflammatory activities of limonin isolated from the fruit of Evodia rutaecarpa var. Bodinieri. Planta Med. 64, 339-342.

102. Li, S.R., Luan, D.M., and Xue, X.Z. (1982) Antioncotic effect on joints by the volatile oil of Thymus quinquicostatus. Chem. Pharm. Bull. 17, 305-307.

103. Craker, L.E. and Simon, J.E. (1987) Herb, Spices and Medicinal Plants. Vol. 2. Recent Advances in Botany, Horticulture, and Pharmacology. Haworth Press, Binghamton, NY.

104. Dekker, T.G., Theunis, F.G., Elmare, M., Snyckers, F., Schyft, V.C., Boeyens, J.C., and Denner, L. (1988) Studies of South African medicinal plants. Part 7. Rhinocerotinoic acid: a labdane diterpene with antiinflammatory properties from Elytropappus rhinocerotis. S. Afr. J. Chem. 41, 33-35.

105. Fujisuke, Y., Masami, Y., and Takuo, K. (1988) New sesquiterpene from Siegesbeckia pubescens as analgesic and anti-inflamatories. Jpn. Kokai Tokkyo Koho JP 62,175476 [87,175,476]. Chem. Abstract. 109: 197169k, 1988.

106. Shibata, S. (1977) In New Natural Products and Plant Drugs with Pharmacological, Biological or Therapeutical Activity. Wagner, H. and Wolff, P., Eds. Springer-Verlag, Berlin. pp. 177-182.

107. Prinsep, M.R. and Thomson, R.A. (1996) Tolypodiol, an antiinflammatory diterpenoid from the cyanobacterium Tolypothix nodosa (HT-58-2). J. Nat. Prod. 59, 786-788.

108. Carvalho, J.T., Silva, M.F., Maciel, M.A., Pinto, A.C., Nunes, D.S., Lima, R.M., Bastos, J.K., and Sarti, S.J. (1996) Investigation of antiinflammatory and antinociceptive activities of trans-dehydrocrotonin, a 19norclerodane diterpene from Croton cajucara. Part 1. Planta Med. 62, 402-404.

109. Ubonwan, P., Sematong, T., Tuchinda, P., Reutrakul, V., and Nahar, N. (1996) Topical antiinflammatory activity of two pimarane diterpenes from Kaempferia pulchra. Phytother. Res. 10, 534-535.

110. Rungeler, P., Castro, G.V., Mora, G., Pahl, H., and Merfort, I. (1998) Study of three sesquiterpene lactones from Tithonia diversifolia on their antiinflammatory activity using transcription factor NF-KB and enzymes of the arachidonic acid pathway as targets. Planta Med. 64, 588-593.

111. Tambe, Y., Tsujiuchi, H., Honda, G., Ikeshiro, Y., and Tanaka, S. (1996) Gastric cytoprotection of the nonsteroidal anti-inflammatory sesquiterpene, $\beta$-caryophyllene. Planta Med. 62, 469-470. 
112. Castro, V., Rungeler, P., Murillo, R., Hernandez, E., Mor,a G., Pahl, H.L., and Merfort, I. (2000) Study of sesquiterpene lactones from Milleria quinqueflora on their anti-inflammatory activity using the thranscription factor NFkB as molecular target. Phytochemistry 53, 257-263.

113. Wang, B., Hong, X., Li, L., Zhou, J., and Hao, X. (2000) Chemical constituents of two Chinese magnoliaceae plants Tsoongiodendron odorum and manglietiastrum sinicum, and their inhibition of platetet agregation. Planta Med. 66, 511-515.

114. Brouillard, R. (1988) Flavonoids and flower colour. In The Flavonoids: Advances in Research since 1980. Harborne, J.B., Ed., Chapman and Hall, London. pp. 525-538.

115. Harbone, J.B. and Baxter, H. (1993) Phytochemical Dictionary. A Handbook of Bioactive Compounds from Plants. Taylor \& Francis, London.

116. Masatasu, K., Susuki, J., Yamada, T., Yoshizaki, M., Kikuche, T., Kadota, S., and Matsuda, S. (1985) Antiinflammatory effect of neolignans newly isolated from the crude drug "Shin-in" (flos magnoliae). Planta Med. 291-293.

117. Zheng, Y.X. (1984) Clinical observations of analgesic action of paeonol sulfanate injection. Chin. Trad. Herbal Drugs 15, 460-462.

118. Hikino, H., Taguchi, T., Fujimura, H., and Hiramatsu, Y. (1977) Antiinflammatory principles of Caesalpinia sappan, wood and of Haematoxylon campechianum wood. Planta Med. 31.

119. Joyce, C.R.B. and Curry, S.H. (1970) The Botany and Chemistry of Cannabis. J. \& A. Churchill, London.

120. Favier, L., Tonn, C., Guereiro, E., Rotelli, A., and Pelzer, L. (1998) Antiinflammatory activity of acetophenones from Ophyosporus axilliflorus. Planta Med. 64, 657-659.

121. Buckingham, J. (1993) Dictonary of Natural Products. Vol. 2. Chapman and Hall, London. pp. 1267-2477.

122. Kulanthaivel, P., Janzen, W.P., Ballas, L.M., Jiang, J.B., Qi-Hu, C., Darges, J.W., Seldin, J.C., Cofied, D.J., and Adams, L.M. (1995) Naturally occurring protein kinase C inhibitors. II. Isolation of oligomeric stilbenes from Caragana sinica. Planta Med. 61, 41-44.

123. Maldonado, E., Apan, T., and Castorena, A.L. (1998) Antiinflammatory activity of phenylpropanoids from Coreopsis mutica var. mutica. Planta Med. 64, 660-661.

124. Cometa, F., Tomassini, L., Nicoletti, M., and Pieretti, S., Phenylpropanoid glycosides. Distribution and pharmacological activity. Fitoterapia LXIV, 195-217.

125. Oriowo, M.A. (1982) Anti-inflammatory activity of piperonyl-4-acryli-cisobutyl-amid, an extractive from Zanthoxylum zanthoxyloides. Planta Med. 44, 54-56.

126. Ozaki, Y., Soekeni, S., Rosina, Y., and Suganda, A. (1989) Antiinflammatory effect of mace, aril of Myristica fragans Houtt, and its active principles. Jpn. J. Pharmacol. 49, 155-164.

127. Matsuda, T., Jitoe, A., Isobe, J., Nakatani, N., and Yonemori, S. (1993) Anti-oxidative and antiinflammatory curcumin-related phenolics from rhizome of Curcuma domestica. Phytochemistry 32, 1557-1560.

128. Perez, H.M., Rabanal, R.M., Torre. M.C., and Rodriguez, B. (1995) Analgesic, anti-inflammatory. Antipyretic and haematological effects of Aethiopinone, an o-naphthoquinone diterpenoid from Salvia aethiopis roots and two hemisynthetic derivatives. Planta Med. 61, 505-509.

129. Kuo, S.C., Chen, S.C., Chen, L.H., Wu, J.B., Gwang, J.P., and Teng, C.M (1995) Potent antiplatelet, antiinflammatory and antiallergic isoflavanquinones from the roots of Abrus precatorius. Planta Med. 61, 307312.

130. Thomson, R.H. (1971) Naturally Occurring Quinones. $2^{\text {nd }}$ ed. Academic Press, London.

131. Thomson, R.H. (1976) Naturally Occurring Quinones. III. Recent Advances. Chapman and Hall, London.

132. Lin, Z.B., Chai, B.L., Wang, Q.K., Lu, F.S., and Xiang, G.Q. (1980) Studies on the anti-inflammatory effect of chemical principle of Zi-Cao Arnebia euchroma (Royle) Johnst. J. Beijing Med. Coll. 12, 101-110.

133. Hiller, K. (1987) New results on the structure and biological activity of triterpenoid saponins. In Biologically Active Natural Products. Hostettmann, K. and Lea, P.J., Eds. Clarendon Press, Oxford. pp. 167-184.

134. Applebaum, S.W. and Birk, Y. (1979) Saponins. In Herbivores: Their Interaction with Secondary Plant Metabolites. Rosenthal, G.A. and Jazen, D.H., Eds. Academic Press, New York. pp. 539-566.

135. Cao, Z.Z., Yu, J.H., Gan, L.X., and Chen, Y.Q. (1985) The structure of astramembrannins. Acta Chim. Sin. 43, 581-585.

136. Shao, Y., Zhou, B., Lin, L., and Cordell, G. (1995) Triterpene saponins from Aster yunnanensis. Phytochemistry 38, 1487-1495.

137. Singh, G.B., Atal, C.K., and Zahn, M. (1986) Pharmacology of an extract of salai guggal from Boswellia serrata, a new steroidal antiinflammatory. Agente Actions 18, 407-412.

138. Hahn, D., Kasai, R., Kim, J., Taniyasu, S., and Tanaka, O. (1984) A new glycosyl ester of a 3,4secotriterpene from Korean medicinal plant Acanthopanax chiisanensis (Araliaceae). Chem. Pharm. Bull. 32, 1244-1247.

139. Shibata, S., Tanaka, O., Shoji, J., and Saito, H. (1985) Chemistry and pharmacology of Panax, economic and medicinal plant research. Yakugaku Zasshi 1, 218-284.

140. Claude, P., Roux, J., and Dieran, R. (1964) Antiphlogistic drug on cryptogenin. Chem. Abstract. 61: 11859.

141. Mahato, S.B. and Nandy, A.K. (1991) Triterpenoid saponins discovered between 1987 and 1989. Phytochemistry 30, 1357-1390. 
142. Sahu, N.P. and Mahato, S.B. (1994) Anti-inflammatory triterpene saponins of Pitchecellobium dulce: characterization of an echinocystic acid bidesmoside. Phytochemistry 37, 1425-1427.

143. Gene, R.M., Cartaña, C., Adzet, T., Marin, E., Parella, T., and Cañigueral, S. (1996) Anti-inflammatory and analgesic activity of Baccharis trimera: identification of its active constituents. Planta Med. 62, 232-235.

144. Just, M.J., Recio, M.C., Ciner, R.M., Cuellar, M.J., Mañez, S., Bilia, A.R., and Rios, J.L. (1998) Antiinflammatory activity of unusual lupane saponins from Bupleurum fruticescens. Planta Med. 64, 404-407.

145. Matsuda, H., Samukawa, K., and Kubo, M. (1990) Anti-inflammatory activity of Ginsenoside Ro. Planta Med. 56, 19-23.

146. Yasukawa, K., Kaminaga, T., Kitanaka, S., Tai, T., Nunoura, Y., Natori, S., and Takido, M. (1998) 3ß-phydroxybenzenzoyldehydrotumulosic acid from Poria cocos, and its antiinflammatory effect. Phytochemistry 48, 1357-1360.

147. Budhiraja, R.D., Sudhir, S., and Garg, K.N. (1977) Anti-inflammatory activity of 3ß-hydroxy-2,3-dihydrowithanolide F. Planta Med. 32, 154-156.

148. Kitagawa, I., Shirakawa, K., and Yoshikawa, M. (1978) Saponin and sapogenol. XXIV. The structure of Misaponin A, a bidesmoside of protobasic acid from seed kernels of Madhuca longifolia L. Macbride. Chem. Pharm. Bull. 26, 1100-1110.

149. Duke, J.A. (1989) Ginseng: A Concise Handbook. Reference Publications, Algonac, MI. pp. 56-59.

150. Tschesche, R. and Wulff, G. (1973) Chemie und biologie der saponine. In Progress in the Chemistry of Organic Natural Products. Vol. 30. Springer-Verlag, Vienna. pp. 461-466.

151. Yu, S., Xiao, Z., Cai, P., Jiang, T., and Snyder, J. (1994) A new triterpenoid saponin from the Chinese traditional medicine Nothopanax davidii Harms (Araliaceae). Tetrahedron 50, 11601-11612.

152. Akihisa, T., Yasukawa, K., Kimura, Y., Takido, M., Kokke, W.C., and Tamura, T. (1994) 7-0x0-10 $2-$ Cucurbitadienol from the seeds of Trichosanthes kirilowii and its anti-inflammatory effect. Phytochemistry 36, 153-157.

153. Woo, W.S. and Kang, S.S. (1976) Phytolaccoside B: triterpene glucoside from Phytolacca americana. Phytochemistry 15, 1315-1317.

154. Chi, H. and Kim, H.S. (1985) Saponins from the callus mass of Phytolacca americana. Arch. Pharmacol. Res. 8, 15-20.

155. Akihisa, T., Yasukawa, K., Kimura, Y., Yamanouchi, S., and Tamura, T. (1998) Sansaquol, a 3,4-secotriterpene alcohol from sasanqua oil, and its antiinflammatory effect. Phytochemistry 48, 301-305.

156. Gupta, M.B., Nath, R., Srivastava, N., Shanker, K., and Bhargava, K.P. (1980) Anti-inflammatory and antipyretic activities of $\beta$-Sitosterol. Planta Med. 39, 157-163.

157. Hema, D.M., Tidjani, E., Bassene, J.L., and Pousset, L. (1987) African medicinal plants. XXIV. Study of the antiinflammatory action of Bryophyllum pinnatum (Crassulaceae). Plant Med. Phytother. 20, 231-235.

158. Salama, A.M., Sanchez, M.L., and Achenbach, H. (1987) Antiinflammatory and cardioactive glucosides from Sechium edule Rev. Latinoamer. Quim. 18, 132-139.

159. Hill, R.A., Kirk, D.N., Makin, H.L.J., and Murphy, G.M. (1991) Dictionary of Steroids. Chapman and Hall, London.

160. Tsai, P., Wang, J., Chang, C., Kuo, S., and Chao, P. (1998) Constituents and bioactive principles of Polygonum chinensis. Phytochemistry 49, 1663-1666.

161. Cuellar, M.J., Giner, R.M., Recio, M.C., Just, M.J., Mañez, S., Cerda, M., Hostettmann, K., and Rios, J.L. (1997) Zanhasaponins A and B antiphospholipase A2 saponins from Zanha africana an antiinflammatory extract of root bark. J. Nat. Prod. 60, 1158-1160.

162. Mahato, S.B., Sarker, S.K., and Poddar, G. (1988) Triterpenoid saponins. Phytochemistry 27, 3037-3067.

163. Calixto, J.B., Zanini, Jr., C., Cruz, A.B., and Madeiros, Y.S. (1991) Extract and compounds obtained from Mandevilla velutina inhibit arachiodonic acid-induced ear oedema in mice, but not at stomach contraction. Prostaglandins 41, 515-525.

164. Yunes, R.A., Pizzolatti, M.G., Santana, A.E., Hawes, G.E., and Calixto, J.B. (1993) The structure of Velutinol A, an anti-inflammatory compound whit a novel pregnane skeleton. Phytochem. Anal. 4, 76-81.

165. Akihisa, T., Yasukawa, K., Oinuma, H., Kasahara, Y., Yamanouchi, S., Tarido, M., Kumaki, K., and Tamura, T. (1996) Triterpene alcohols from the flowers of Compositae and their anti-inflammatory effects. Phytochemistry 43, 1255-1260.

166. Hasmeda, M., Okai, G., Macrides, T., and Polya, G. (1999) Selective inhibition of eukaryote protein kinases by antiinflammatory triterpenoids. Planta Med. 65, 14-18.

167. Recio, M.C., Giner, R.M., Mañez, S., Talens, A., Cubells, L., Gucho, J., Julien, H.R., Hostettmann, K., and Rios, J.L. (1995) Investigations on the steroidal anti-inflammatory activity of triterpenoids from Diospyros leucomelas. Planta Med. 61, 9-12.

168. Hostettmann, K. and Hostettmann, M. (1989) Xanthones in Plant Phenolics. Vol. 1. Methods in Plant Biochemistry. Harbone, J.B., Ed. Academic Press. London. pp. 493-508.

169. Bennett, J.G. and Lee, H.H. (1989) Xanthones from Guttiferae. Phytochemistry 28, 967-998.

170. Mandal, S., Das, P.C., Joshi, P.C., Chatterje, A., Islam, C.S., Dutta, M.R., Patra, B.D., and Sikdar, S. (1992) Anti-inflammatory action of Swertia chirata. Fitoterapia LXIII, 122-128. 


\section{ADDITIONAL REFERENCES}

Claeson, P., Pongprayoon, U., Sematong, T., Tuchinda, P., Reutrakul, V., Soontornsaratune, P., and Taylor, W.C. (1996) Non-phenolic linear diarylheptanoids from Cucurma xanthorrhiza: a novel type of topical antiinflammatory agents: structure-activity relationship. Planta Med. 62, 236-240.

Pereira, B.M.R., Da Silva, B.P., Pereira, N.A., and Parente, J.P. (2000) Antiiflammatory and immunologically active polysaccharides of Periandra mediterranea. Phytochemistry 54, 409-413.

Recio, M.C., Giner, R.M., Mañez, S., and Talens, A. (1995) Structural requirements for the anti-inflammatory activity of natural triterpenoids. Planta Med. 61, 182-185.

Shibata, M., Yamatake, Y., and Amagaya, Y. (1975) Pharmacological studies on the Chinese crude drug "Shoma". Acute toxicity and antiinflammatory actions of Cimicifuga rhizoma, Cimicifuga dahurica Maxim. Yakugaku Zasshi 95, 539-546.

This article should be referenced as follows:

Perez G., R.M. (2001) Anti-inflammatory activity of compounds isolated from plants. TheScientificWorld 1, 713-784.

\section{Handling Editor:}

Edward J. Goetzl, Principal Editor for Inflammation — a domain of TheScientificWorld.

\section{TABLE 1}

Mechanism of Action of Several Compounds Isolated from Plants with Anti-Inflammatory Activity
A. Supress platelet function
B. Inhibit eicosanoid mediator generation or activities
C. Block $\mathrm{O} 2$ radical formation or effects

D. Alter cytokine production or effects

\author{
Curcumin \\ Isoflavanquinones (abruinonones A, B, D, and F) \\ Diterpenoids (Aethiopinone) \\ Quinoid aporphine alkaloids \\ o-Naphthoquinone diterpene \\ The coumarins - herniarin, aesculetin, scopolin, and \\ scopoletin \\ Chamazulene \\ The coumaric, caffeic acid, ferulic acid, and derivatives \\ (methyl caffeate, methyl feulate and bornyl ferulate) \\ (-) Epicatechin, (-) epiafzelechin, artemetin \\ Flavonoids (quercetin and kaempferol) \\ The flavan 3-ol derivatives, $4^{\prime}$-O-methyl-ent-gallocatechin, \\ $(+)$-gallocatechin, mearnsitrin, myricitrin and quercitrin \\ 6-Hydroxyflavonoids as 6-hydroxykaempferol, 3,6- \\ dimethyl ether, and 6-hydroxyluteolin \\ The ocobullenone \\ Polyacetylenes \\ Sesquiterpene lactone hydroxyachillin \\ The pimarane diterpenes ( $2 \alpha$-acetoxysandara- \\ copimaradien, maxikdiol and sandara-copimaradien- \\ $1 \alpha, 2 \alpha$-diol) \\ Sesquiterpene lactones (diversifolin, methyl ether, and \\ tirotundin) \\ Sesquiterpene lactones of the germacranolide-type
}


E. Block lysosomal enzymes

F. Antagonize other low m.w. mediators

G. Inhibit leukocyte function

H. Other effects (melampolides and millerenolides)

Acid phosphatase and cathepsin D

Flavonoids (hypolaetin-8-glucoside)

Hypolaetin-8-glucoside

Isoflavanquinones (abruinonones A, B, D, and F)

Quercetin and kaempferol

$\alpha$-Amyrin and lupeol and the palmitate and linoleate esters of these triterpenoids

Baicalein, baicalin, and wogonin

Fagaramide, velutinol A

Glycoside nepretin

The kaempferol 3-O-sophoroside

Lithocholic acid, $18 \alpha-$ and 18 $\beta$-glycyrrhetinic acid, 5cholenic acid-3 $\beta$-ol, lithocholic acid methyl ester, ursolic acid, and oleanolic acid

Nimbidin and bradykinin, benzoxazinoid

The oligomeric stilbenes $[(+)-\alpha$-viniferin, miyanenol, and kobophenol]

The saponin echinocystic acid

Sesquiterpene lactone (limonin)

Sesquiterpene lactones (diversifolin, diversifolin methyl ether, and tirotundin)

Several phenolic diarylheptanoids

Bukittinggine

Epicatechin, catechin procyanidin $\mathrm{B}_{2}$,

5,7 Dimethoxyflavone

Gossypetin-8-glucoronide (hibifolin)

The oleanane-type triterpene saponins zanha-saponins $A$ and $B$

Hypolaetin-8-glucoside

Several triterpenoids belonging to the lupane, Oleanane and ursane series

Procyanidin $\mathrm{B}_{4}$, cinnamonol $\mathrm{D}_{1}$ and cinnamonol $\mathrm{D}_{2}$,

Quercetin glycosides

Acetophenones

Anthocyanins

Benzophenanthridine (BPA) alkaloids (sanguinarine, chelerythrine, and chelidonine)

Clerodane diterpene:19-nor clerodane diterpene

The bicycle form of sesquiterpene molecule with four and nine members rings ( $\beta$-caryophyllene)

Non-phenolic diarylheptanoids

The pimarane diterpenes ( $2 \alpha$-acetoxysandaracopimaradien, maxikdiol and sandara-copimaradien$1 \alpha, 2 \alpha$-diol)

The betulinic acid and betulin

The ingenase-type diterpene structurally related to phorbol

Lupeol

The triterpenes - saponin, glycyrrhizin, and glycyrrhetic acid

$\alpha$-Spinasterol

Saponin echinocystic

Vitexin 
TABLE 2

Applications of Several Compounds Isolated from Plants with Anti-Inflammatory Activity

\begin{tabular}{|c|c|c|}
\hline Compound & Administration & Uses \\
\hline Acetophenones & p.o. & $\begin{array}{l}\text { Used in folk medicine in Argentina for its anti-inflammatory } \\
\text { properties. }\end{array}$ \\
\hline Aescin ( $\beta$-amyrin derivative) & p.o. & $\begin{array}{l}\text { Used as a folk medicine in France and the tincture of this } \\
\text { drug has been used for haemorrhoid, and in the } \\
\text { treatment of varicose vein. }\end{array}$ \\
\hline Aesculetin & p.o. & $\begin{array}{l}\text { Used in Spain as a folk remedy against a variety of diseases } \\
\text { such as inflammatory complaints and to achieve } \\
\text { beneficial effects on the digestive tract. }\end{array}$ \\
\hline$\alpha$-Amyrin & p.o. & Used as a remedy for arthritis. \\
\hline $\begin{array}{l}\text { 3-O-[ } \alpha \text {-L-arabinopyranosyl-(1- } \\
\text { 2) - } \alpha \text {-L- } \\
\text { arabinopyranosyl]olean-12- } \\
\text { ene-28,29dioic acid[O- } \alpha-L- \\
\text { rhamnopyranosyl- }(1-4) \beta-D- \\
\text { glucopyranoside. }\end{array}$ & p.o. & $\begin{array}{l}\text { Show various pharmacological activities including increasing } \\
\text { mental efficiency, recovering physical balance, } \\
\text { stimulation of metabolic function, and other general } \\
\text { health promoting effects. }\end{array}$ \\
\hline Anemonin and protoanemonin & p.o. & $\begin{array}{l}\text { Have commonly been used as analgesic, diuretic, and anti- } \\
\text { inflammatory agents. }\end{array}$ \\
\hline Arachidonic acid & $\begin{array}{l}\text { p.o. } \\
\text { topically }\end{array}$ & $\begin{array}{l}\text { Used in South America in traditional medicine internally for } \\
\text { the treatent of rheumatism, hepatobiliary disorders, and } \\
\text { diabetes; externally, in cases of skin ulceration and } \\
\text { wounds. }\end{array}$ \\
\hline Artemetin & topically & $\begin{array}{l}\text { Used in Brazilian folk remedies as anti-inflammatory and } \\
\text { cicatrizing agents. }\end{array}$ \\
\hline $\begin{array}{l}\text { Baicalein, baicalin, and } \\
\text { wogonin }\end{array}$ & p.o. & $\begin{array}{l}\text { Used for treatment of some types of dermatitis, diarrhea, and } \\
\text { various inflammatory diseases as an antiphologistic and } \\
\text { antipyretic in traditional Chinese medicine. }\end{array}$ \\
\hline Bassic acid & p.o. & $\begin{array}{l}\text { Used in Brazilian folklore in the treatment of inflammatory } \\
\text { disorders. }\end{array}$ \\
\hline Benzoxazinoid & p.o. & $\begin{array}{l}\text { Used in China for a long time for the treatment of rheumatism } \\
\text { and neuralgia. }\end{array}$ \\
\hline Bergenin & topically & $\begin{array}{l}\text { An ingredient of gagles, tooth powders, and lotions used for } \\
\text { eye troubles, muscular pains, and sores. }\end{array}$ \\
\hline Boswellic acid & topically & $\begin{array}{l}\text { Used in Ayurvedic system of medicine "Salai guggal" in India. } \\
\text { Effective in controlled clinical trials in arthritis patients. } \\
\text { Released for therapeutic use under the trade name } \\
\text { "Sallaki". }\end{array}$ \\
\hline Brazilin and hematoxylin & p.o. & $\begin{array}{l}\text { Have long been used as emmenagogue, as analgesic, as } \\
\text { astringent antidiarrhoic, and as cure for contution and } \\
\text { sprain in Oriental medicine. }\end{array}$ \\
\hline Bukittinggine & p.o. & $\begin{array}{l}\text { Used in West Sumatra, Indonesia to treat bronchial asthma } \\
\text { and to relieve pain. }\end{array}$ \\
\hline Calophyllolide & i.p. and p.o. & $\begin{array}{l}\text { Used for the treatment of rheumatism, sore, eyes, scabies, } \\
\text { gout in the Indian system of medicine. }\end{array}$ \\
\hline Chamazulene & p.o. & $\begin{array}{l}\text { The preparations from chamomile are used in the treatment } \\
\text { of inflammatory diseases of skin and intestinum. }\end{array}$ \\
\hline Chikusetsusaponin V & p.o. & Long used in Japan as antitussive and expectorant. \\
\hline Chimaphilin & p.o. & $\begin{array}{l}\text { Found in the group of Chinese crude drugs called Qu-feng- } \\
\text { shi-yao, which has long been used as a remedy mostly } \\
\text { for arthritic diseases in traditional Chinese medicine. }\end{array}$ \\
\hline Cis-communic acid & topically & $\begin{array}{l}\text { Traditionally used in Chinese medicine for the treatment of } \\
\text { eczema, eruption, swelling, injury, etc. by topical } \\
\text { application. }\end{array}$ \\
\hline Cryogenin and nesodine & p.o. & $\begin{array}{l}\text { Shown to exert significant anti-inflammatory activity in } \\
\text { different disorders. }\end{array}$ \\
\hline Cucurbitacin B & p.o. & $\begin{array}{l}\text { Used as a folk medicine in Turkey for the treatment of } \\
\text { sinusitis and arthritis. }\end{array}$ \\
\hline
\end{tabular}


Curcumin

Cyanidanol

Dauricine

Trans-dehydrocrotonin

1,7-Diarylheptanoids

5,7 Dimethoxyflavone

Ephedrine

Flavonoid glycoside

Flavonoids

Ginsenoside $\mathrm{Ro}^{1}$

Germacranolides

Glycyrrhetinic acid

Glycyrrhizin

Gossypin

Helenalin

3ß-Hydroxy-2,3-dihydrowithanolide $\mathrm{F}$

$3 \beta$-Hydroxybenzoyldehydrotumulosic acid

Hydroxyachillin

Hypolaetin-8-O-glucoside

Isoflavanquinones

Kaempferol

Lignans and neolignans

Limonin

Lupane saponins

Magniferin p.o.

p.o.

p.o.

p.o. and topically

p.o.
p.o.
p.o.
topically

topically

p.o.

p.o.

p.o.

p.o. topically

p.o.

p.o. topically

p.o.

p.o.

p.o.

p.o.

p.o.

p.o.

p.o.

p.o.

p.o.

p.o.
Should be a useful antiarthritic drug without the side effects commonly encountered with other nonsteroidal antiinflammatory drugs. Used as agent for local application on infected wounds including malignancies.

Used in Europe for the treatment of liver diseases (for 20 years).

Used in traditional Chinese medicine for testing rheumatism.

Widely known in traditional phytotherapy for the treatment of diabetes, diarrhea, gastrointestinal disorders, and liver diseases. Used in the Amazon region (Brazil) in the form of tea or powdered and dried pills.

In Thailand, commonly used externally for the treatment of acne and skin inflammations.

Used in the folk medicine of Thailand as a remedy for arthritis.

The crude drug mao is famous for containing alkaloids of the ephedrine series having sympathomimetic, antiallergic activity, perspiratory, and antitussive.

Used for the treatment of injury.

A traditional medicine in China (jiangxiang). Used to treat blood disorder, ischemia, swelling, necrosis, and rheumatic pain.

Widely prescribed in Chinese medicine in general practice. Effective in the management of psychosomatic diseases such as indefinite complaints, stress ulcer, and anxiety neurosis.

Used in the Philippines for sore eyes, coughs, infections of stomach and intestines, itching and for snake and scorpion bites.

Used in African ethnomedicine for treatment of various diseases including arthritic conditions.

Used in Western and Oriental medicine as an expectorant, antitussive, and as a sweetening adjuvant.

Used as a remedy for arthritis.

Used as a remedy for arthritis.

Used in India for a number of ailments especially in skin infections, inflammatory conditions, asthma, chronic liver complications, and as sedatives.

Used in Chinese prescriptions as a diuretic and as a sedative.

Used since ancient times in Spanish traditional medicine as an anti-inflammatory and antirheumatic agent, and for their benificial effects on the digestive tract.

Employed in Spanish folk medicine as an anti-inflammatory and antirheumatic agent.

Used in China for the treatment of laryngitis, hepatitis, and bronchitis.

Used as antipyretic, refrigerant, useful against thirst, leprosy, and leucoderma.

Long used for treatment of headaches, as a tranquilizer and analgesic, and is considered to be especially efficacious for empyem, chronic inflammation of paranasal sinuses. A traditional Chinese herbal medicine know as "Shin-i".

Used for treatment of headache, thoracicoabdominal pain, and vomiting, as an analgesic agent or cold remedy, and as an improving agent of blood circulation in traditional Chinese medicine.

Listed officially in Chinese and Japanese pharmacopoeias and used in Asian traditional medicine to treat certain disorders thar are accompanied by inflammation.

Used as a remedy for arthritis, and antimalarial and liver tonic. 
Marmin

Maslinic acid

Nimbidin

Ocubellenone

Osthol

Phenanthrene derivatives

Phytolaccoside B

Polyacetylenes

Polysaccharides

Quillaic acid

Saikosaponins

Sesquiterpenes

Sesquiterpene Lactones

Sinoacutine

$\beta$-Sitosterol

Taspine

Trilobine and isotrilobine

3,4-Seco triterpene

Ursolic acid

Velutilol A

Vitexin

Zanhasaponins A and B p.o.

p.o. topically

p.o.

p.o.

topically

p.o.

p.o.

p.o.

p.o.

p.o.

p.o.

p.o.

p.o.

i.p.

p.o.

p.o.

p.o.

p.o.

i.p.

p.o.

p.o.
Used as antidiarrhoeitic and antidote to snake venom.

Topical application traditionally used for the treatment of prickly heat, eczema, and other skin diseases.

Possesses antigastric ulcer activity, prevents ulceration by reducing gastric secretion, useful as a liniment for rheumatic affections.

Used in the traditional medicine of Southern Africa for headaches, injury, and magical purposes.

Found in the Chinese crude drug called "Qu-feng-shi-yao"; used as a remedy for arthritis diseases, lumbago, edema, and common cold.

Used in the folk medicine in Paraguay as anti-inflammatory when applied topically.

Used in Korean medicine to alleviate rheumatism.

A traditional remedy in Hawaiian folk medicine for treating general debility of the body, throat, and stomach disorders, and of asthma.

Widely used in Brazilian ethnomedicine as a cough suppressant, anti-inflammatory, and expectorant.

Used as a analgesic and as a anti-inflammatory.

Used in Chinese medicine for the treatment of inflammation of diaphragm and enlargement of liver caused by hepatitis.

Used as a remedy for arthritis diseases.

Used in Central America as a remedy for skin infections.

Used in the folk medicine in South Africa; this alkaloid exhibited slight anti-inflammatory activity; used as a remedy for arthritis.

Used for the treatment of rehumatism.

Used for the treatment of rheumatism by the Peruvian Indian.

Used for the treatment of rehumatism.

Used as an antirheumatic, anti-inflammatory, and tonic in Korea.

Used in traditional Chinese medicine only for arthritic diseases.

Used as a folk medicine in Brazil; bradykinin antagonist; possesses low oral activity and very short-lived systemic activity; used as an analgesic, anti-inflammatory, and as an antirheumatic.

Exhibited moderate anti-inflammatory activity; used as antiinflammatory, hypotensive, and antispasmodic .

Used in traditional medicine in Southern Africa for the treatment of dysentery. 

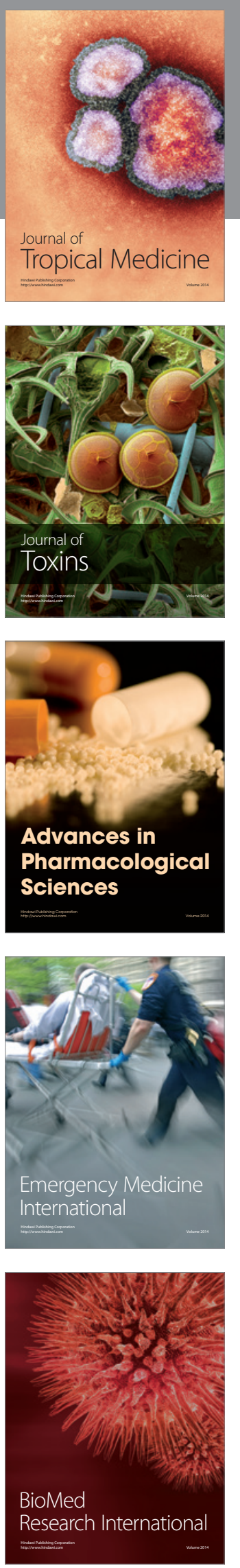
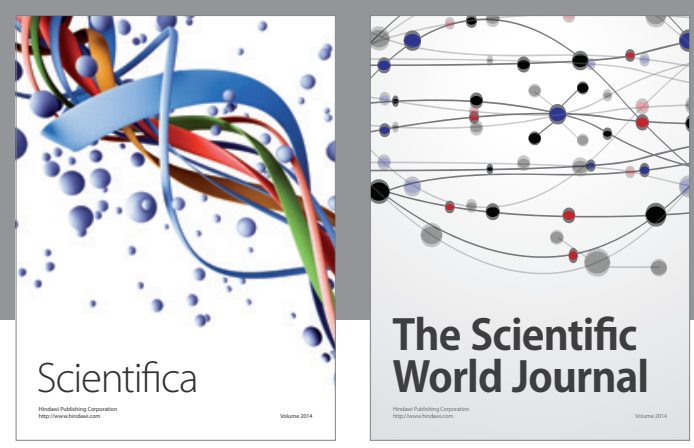

The Scientific World Journal
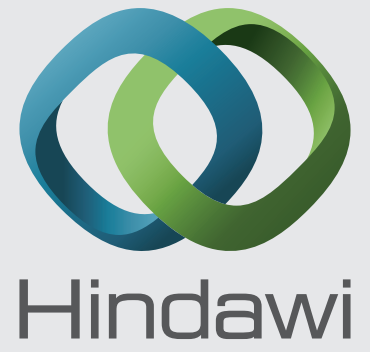

Submit your manuscripts at

http://www.hindawi.com
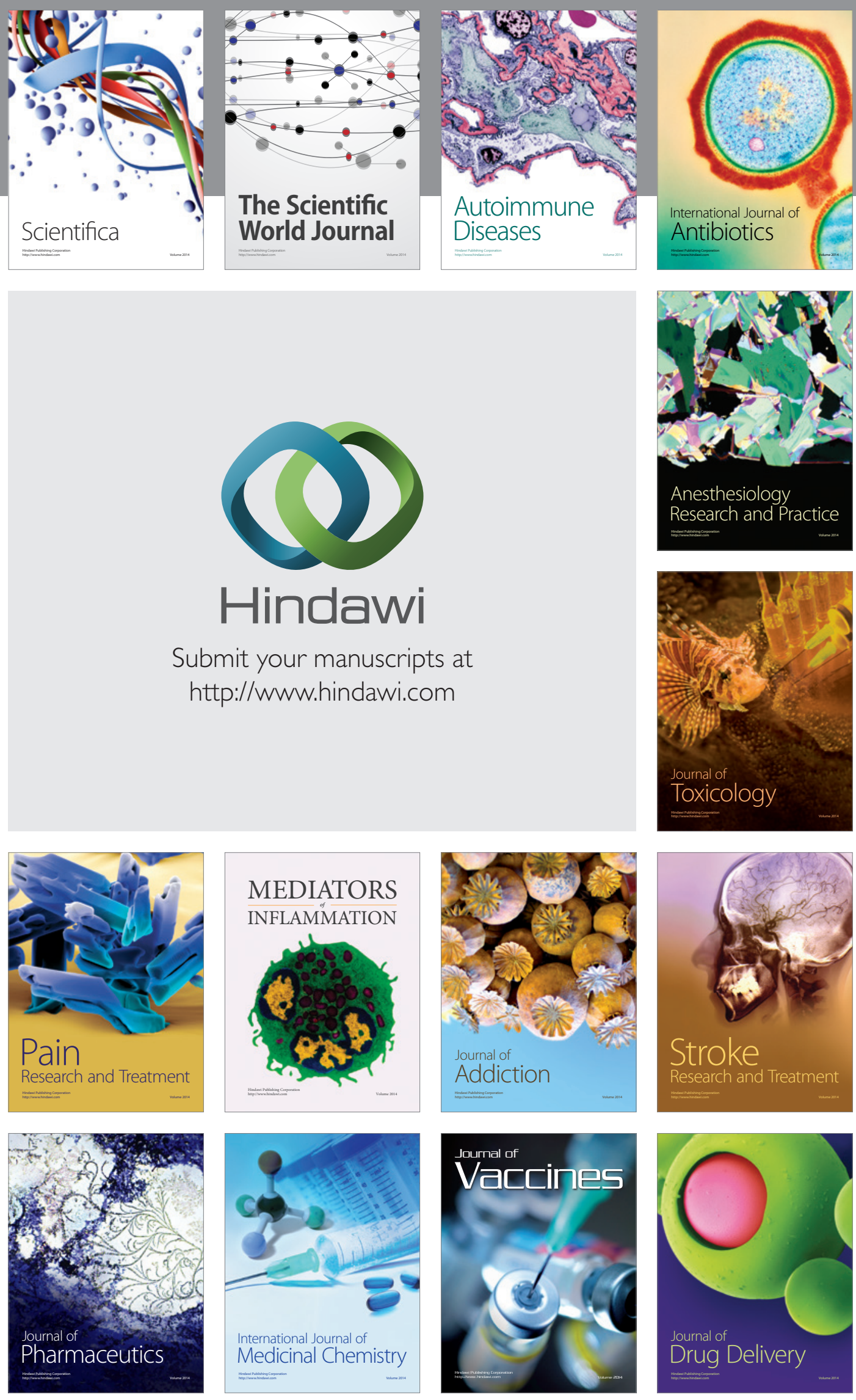